Argonne

\title{
Onsite and Electric Power Backup Capabilities at Critical Infrastructure Facilities in the United States
}

Global Security Sciences Division 


\begin{abstract}
About Argonne National Laboratory
Argonne is a U.S. Department of Energy laboratory managed by UChicago Argonne, LLC under contract DE-AC02-06CH11357. The Laboratory's main facility is outside Chicago, at 9700 South Cass Avenue, Argonne, Illinois 60439. For information about Argonne and its pioneering science and technology programs, see www.anl.gov.
\end{abstract}

\title{
DOCUMENT AVAILABILITY
}

Online Access: U.S. Department of Energy (DOE) reports produced after 1991 and a growing number of pre-1991 documents are available free via DOE's SciTech Connect (http://www.osti.gov/scitech/)

Reports not in digital format may be purchased by the public from the National Technical Information Service (NTIS):

U.S. Department of Commerce

National Technical Information Service

5301 Shawnee Rd

Alexandra, VA 22312

www.ntis.gov

Phone: (800) 553-NTIS (6847) or (703) 605-6000

Fax: (703) 605-6900

Email: orders@ntis.gov

Reports not in digital format are available to DOE and DOE contractors from the Office of Scientific and Technical Information (OSTI):

U.S. Department of Energy

Office of Scientific and Technical Information

P.O. Box 62

Oak Ridge, TN 37831-0062

www.osti.gov

Phone: (865) 576-8401

Fax: (865) 576-5728

Email: reports@osti.gov

\section{Disclaimer}

This report was prepared as an account of work sponsored by an agency of the United States Government. Neither the United States Government nor any agency thereof, nor UChicago Argonne, LLC, nor any of their employees or officers, makes any warranty, express or implied, or assumes any legal liability or responsibility for the accuracy, completeness, or usefulness of any information, apparatus, product, or process disclosed, or represents that its use would not infringe privately owned rights. Reference herein to any specific commercial product, process, or service by trade name, trademark, manufacturer, or otherwise, does not necessarily constitute or imply its endorsement, recommendation, or favoring by the United States Government or any agency thereof. The views and opinions of document authors expressed herein do not necessarily state or reflect those of the United States Government or any agency thereof, Argonne National Laboratory, or UChicago Argonne, LLC. 


\section{Onsite and Electric Power Backup Capabilities at Critical Infrastructure Facilities in the United States}

by

Julia A. Phillips, Kelly E. Wallace, and Terence Y. Kudo

Global Security Sciences Division, Argonne National Laboratory

Joseph H. Eto

Lawrence Berkeley National Laboratory

April 2016 



\section{Contents}

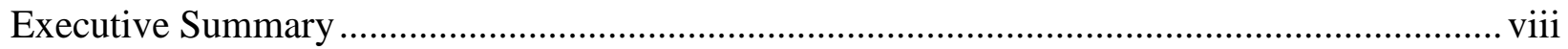

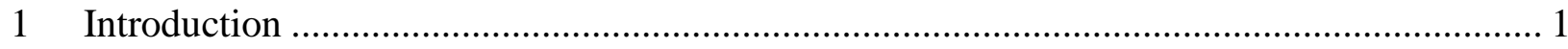

2 Creating Facility Groupings for Analysis........................................................................ 3

3 External Electric Power Dependence ............................................................................... 7

4 External Electric Power Mitigation Measures ....................................................................... 9

$4.1 \quad$ Internal Electric Generation Capability ........................................................................ 11

4.2 Backup Electric Generation Capability .................................................................. 13

4.3 Backup Generators ........................................................................................... 14

4.3.1 Backup Generator Duration .......................................................................... 14

4.3.2 Backup Generator Fuel Type ............................................................................... 15

$4.4 \quad$ Uninterruptible Power System (UPS) ……………………………………………...... 21

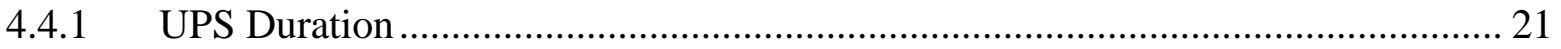

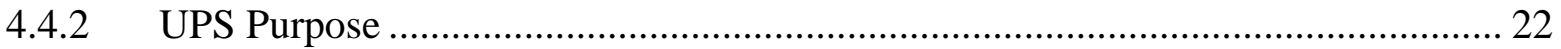

4.5 Facilities with UPS and Backup Generation ............................................................... 24

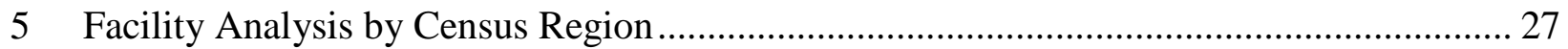

5.1 External Electric Power Dependence by Census Region.................................................. 30

5.2 External Electric Power Mitigation Measures by Census Region ................................... 32

5.2.1 Internal Generation Capability by Census Region..................................................... 33

5.2.2 Alternate or Backup by Census Region ............................................................ 35

5.2.3 Backup Generators by Census Region............................................................. 37

5.3 UPS by Census Region ...................................................................................... 43

5.3.1 UPS Duration by Region ................................................................................ 46

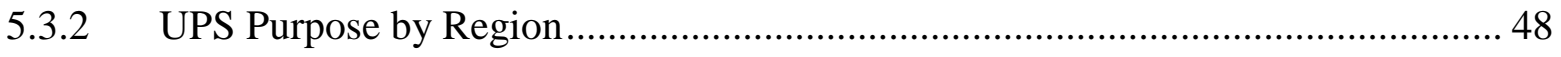

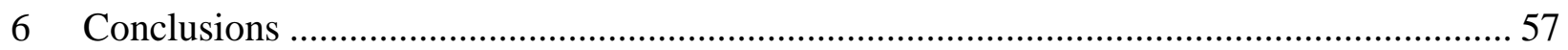

\section{Figures}

1 Distribution of Load Capacity for Facilities with Less than Full Facility

Load Internal Generation Capability 12

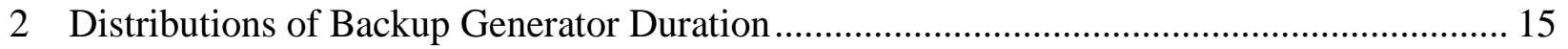

3 Duration of Backup Generator by Fuel Type …………...................................................... 16

4 Percent of Facilities, by Study Group, with Natural Gas Backup Generators......................... 18 


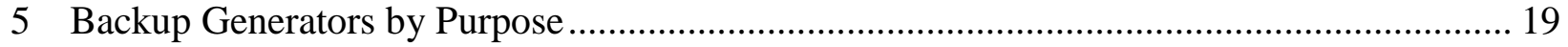

6 Duration of Backup Generator by Purpose .......................................................................... 19

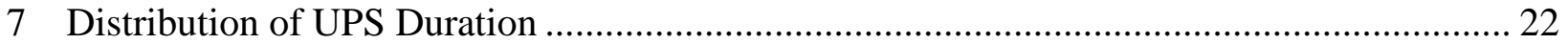




\section{Figures (Cont.)}

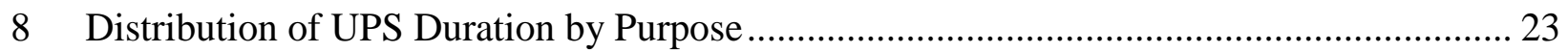

9 Percentage of Full Facility Load that the Facilities without Full Capacity can Sustain .................................................................................................................. 35

10 Backup Generation by Census Region ........................................................................ 40

11 Boxplots of Backup Generator by Purpose and Census Region .......................................... 42

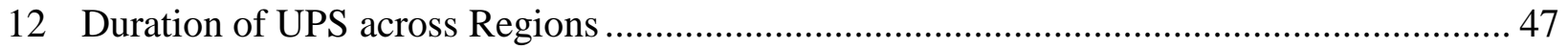

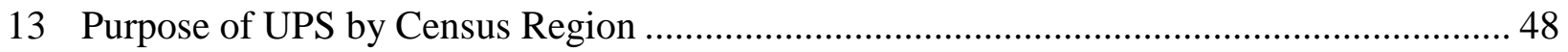

14 Boxplots UPS Duration by Purpose and Census Region ..................................................... 55

\section{Tables}

1 Groups within the Critical Infrastructure Taxonomy ......................................................... 4

2 Forty-nine (49) Facility Groupings for Analysis ..................................................................... 5

$3 \quad$ Facilities that Depend on External Electrical Power by Study Group ....................................... 7

4 Facility Mitigation Measures by Group …………….................................................... 9

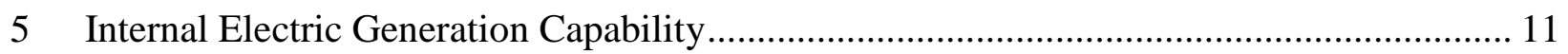

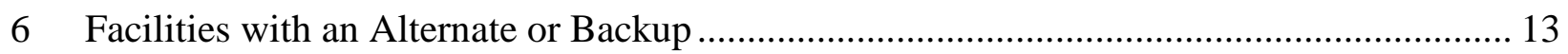

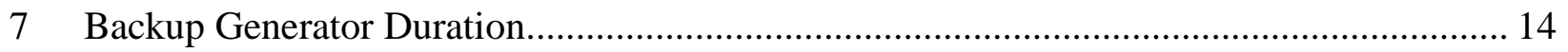

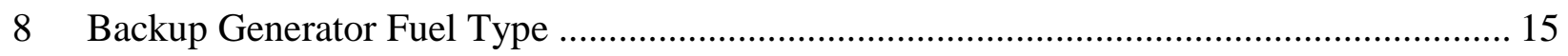

9 Percentage of Facilities with a Backup Generator That Use Each Type of Fuel ................... 16

10 Backup Generator Purpose and Duration ....................................................................... 19

11 Purpose of Backup Generation by Study Group ……........................................................ 20

12 Distribution of UPS Duration...................................................................................... 22

13 Average UPS Duration by Purpose ……………........................................................... 22

14 UPS by Purpose ............................................................................................. 23

15 UPS and Backup Generator Purpose for Facilities with Both................................................ 25

16 Number of Facilities by Groups for the Four Census Regions ............................................ 27

17 Number of Facilities by Taxonomy Level for the Four Census Regions.............................. 28

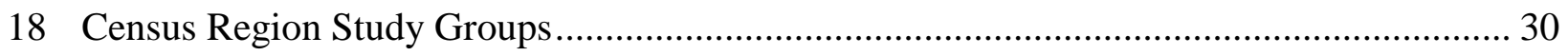

19 External Electrical Power Dependence by Census Region .................................................. 30

20 Group A Facilities Dependent upon External Electrical Power, by Census Region.............. 31

21 Group B Facilities That Depend upon External Electrical Power, by Census Region .......... 32 


\section{Tables (Cont.)}

22 Electric Dependence Mitigation Measures by Region ........................................................... 32

23 Internal Generation Capability by Census Region (Group A) ............................................... 33

24 Internal Generation Capability by Census Region (Group B) .............................................. 34

25 Internal Generation Capacity Less than Full Facility Load by Census Region ..................... 34

26 Percentage of Facilities with an Alternate or Backup, by Census Region (Group A) ........... 35

27 Percentage of Facilities with an Alternate or Backup by Census Region (Group B) ............ 36

28 Backup Capabilities by Census Region........................................................................... 37

29 Facilities with a Backup Generator by Census Region (Group A) …………….................... 38

30 Facilities with a Backup Generator by Census Region (Group B)......................................... 39

31 Backup Generation Duration by Census Region................................................................... 39

32 Average Duration of Backup Generator in Hours by Census Region (Group A) .................. 40

33 Average Duration of Backup Generator in Hours by Census Region (Group B) ................... 41

34 Backup Generator Typea and Duration by Census Region.................................................... 42

35 Percent with a UPS by Census Region (Group A) ............................................................... 43

36 Percent with a UPS by Census Region (Group B) ............................................................... 44

37 UPS Duration in Hours by Census Region (Group A)......................................................... 45

38 Average Duration of UPS in Hours by Census Region (Group B) ..................................... 46

39 Distribution of UPS Duration by Census Region................................................................ 47

40 Average and Median UPS Duration by Census Region.......................................................... 47

41 Percent of Facilities with UPS by Census Region (Group A) UPS Purpose: Life Safety ................................................................................................... 48

42 Percent of Facilities with UPS by Census Region (Group A) UPS Purpose: Graceful Shutdown ................................................................................. 50

43 Percent of Facilities with UPS by Census Region (Group A) UPS Purpose: Core Operations ......................................................................................... 51

44 Percent of Facilities with UPS by Census Region (Group A) UPS Purpose: Entire Facility Load ................................................................................. 52

45 Percent of Facilities with UPS by Census Region (Group B) UPS Purpose: Life Safety.

46 Percent of Facilities with UPS by Census Region (Group B) UPS Purpose: Graceful Shutdown 


\section{Tables (Cont.)}

47 Percent of Facilities with UPS by Census Region (Group B) UPS Purpose: Core Operations ............................................................................................... 54

48 Percent of Facilities with UPS by Census Region (Group B) UPS Purpose: Entire Facility Load ................................................................................ 54 
Onsite and Electric Power Backup Capabilities at Critical Infrastructure Facilities in the United States

This page intentionally left blank. 


\section{Acknowledgements}

The authors gratefully acknowledge the contributions of members of both the Department of Energy, Electricity Delivery and Energy Reliability (DOE-OE) and the Department of Homeland Security, Office of Infrastructure Protection, Protective Security Coordination Division (DHS/IP PSCD). The authors are particularly grateful for the support and vision of Mr. Dan Ton (DOEOE) and Ms. Jamie Richards (DHS/IP). Their positive corroboration brought together the knowledge of two federal agencies in support of a topic that is critical to the entire nation. 
Onsite and Electric Power Backup Capabilities at Critical Infrastructure Facilities in the United States

This page intentionally left blank. 


\section{Executive Summary}

The following analysis, conducted by Argonne National Laboratory's (Argonne's) Risk and Infrastructure Science Center (RISC), details an analysis of electric power backup of national critical infrastructure as captured through the Department of Homeland Security's (DHS's) Enhanced Critical Infrastructure Program (ECIP) Initiative. Between January 1, 2011, and September 2014, 3,174 ECIP facility surveys have been conducted. This study focused first on backup capabilities by infrastructure type and then expanded to infrastructure type by census region. Some of the key findings are listed below:

Insights across all assessed infrastructure:

- More than half of the study groups analyzed during this effort rely on external sources of electric power to maintain core operations. Of the assessed study groups, 30 of the 49 groups had reported that 100 percent of facilities dependent on an external electrical power source.

- Eighty percent of the assessed facilities that rely on external electric power have a mitigation system in place, with the majority having an alternate or backup. One hundred percent of the following assessed facility groups have an alternate or back power in place: Banking and Finance; Critical Access Hospitals; Private or Private Not-for-Profit General Medical and Surgical Hospital; State, Local, or Tribal General Medical and Surgical Hospital.

- Of the facilities with an internal power source, 67 percent reported that internal generation could sustain the full facility load. The remaining 33 percent could, on average, sustain 40 percent of the peak facility demand. Facility groups with the highest number of facilities with internal generation capabilities include: Hydropower Plants (19); Coal-fired Generators (19); Electricity Generation (13); Wastewater Treatment Plants (13).

Insights on infrastructure by census region:

- Based on census region, the Northeast has the highest percentage of facilities dependent on external electric power (95 percent), followed by the Midwest (93 percent), the South (92 percent), and the West (82 percent), respectively. However, in terms of average duration in hours of backup generation by census region, the Northeast has the greatest average number of hours (464), followed by the South (408), the Midwest (364), and the West (141).

- The West census region has a noticeably lower percentage of natural gas generators (which have the longest duration time), and those they do have do not last as long, on average, as other regions. Although the Northeast and South census regions do not have the largest percentage of natural gas generators, their average duration is almost double the duration of the generators in the Midwest and over three times the duration of the generators in the West. 
Although the surveyed sample size is small with regard to the entirety of critical infrastructure across the country, the facilities that have been surveyed through the ECIP program lend some interesting insight into potential differences in backup capabilities and methods across both infrastructure types and regions of the country. 


\section{Introduction}

Argonne National Laboratory’s (Argonne’s) Risk and Infrastructure Science Center (RISC) conducted an analysis of the electric power backup capabilities of national critical infrastructure as captured through the Department of Homeland Security's (DHS's) Enhanced Critical Infrastructure Program (ECIP) Initiative. The ECIP Initiative is one of many programs DHS uses to gain insight on the protection and resilience postures of the Nation's critical infrastructure. The Initiative consists of "a voluntary assessment that includes outreach, which establishes or enhances the Department of Homeland Security's (DHS) relationship with critical infrastructure owners and operators and informs them of their facilities' importance and need for vigilance, and security surveys, which are conducted by DHS protective security advisors (PSAs) to assess the overall security and resilience of the nation's most critical infrastructure sites.”1 Backup capability information is collected in support of the ECIP Initiative through the Infrastructure Survey Tool (IST) - a critical infrastructure survey tool that contains more than 1,500 data collection points related to both protection and resilience measures that can exist at a facility. The PSA inputs answers to the survey questions into an online database where an extensive quality assurance process is used to ensure accuracy and consistency of data collected. Once the information has been verified, it is run through scoring algorithms to assign relative values to the facilities overall resilience and protection. The owners of the critical infrastructure receive an interactive dashboard that they can use to examine how their resilience and protection postures compare to like facilities, and to explore options for enhancing their protection and/or resilience. The DHS maintains the database and uses the information to search for gaps in resilience and protection to identify needs (e.g., funding, outreach) for groups of critical infrastructure. Between January 1, 2011, and September 2014, 3,174 ECIP facility surveys have been conducted.

The DHS collects information on critical infrastructure following the Critical Infrastructure Taxonomy, the top level of which is the sector level. This taxonomy was created "to promote a common infrastructure terminology for the Department and its mission partners.”2 Many foundational documents established the 18 critical infrastructure sectors to include Presidential Decision Directive (PDD)/NSC-63, ${ }^{3}$ and Development of Homeland Security Presidential Directive (HSPD) - 7: Critical Infrastructure Protection Plans to Protect Federal Critical Infrastructures and Key Resources. ${ }^{4}$ These critical infrastructure sectors are Agriculture and Food; Banking and Finance; Chemical and Hazardous Materials Industry; Commercial Facilities; Communications; Dams; Defense Industrial Base; Emergency Services; Energy; Government Facilities; Healthcare and Public Health; Information Technology; Manufacturing; National Monuments and Icons; Nuclear Reactors, Materials, and Waste; Postal and Shipping;

${ }^{1}$ Enhanced Critical Infrastructure Protection, Department of Homeland Security, http://www.dhs.gov/ecip, accessed 26 Aug 2015.

2 Infrastructure Data Taxonomy, Department of Homeland Security, https://www.dhs.gov/infrastructure-datataxonomy, accessed 23 Mar 2015.

3 Presidential Decision Directive 63, Critical Infrastructure Protection, May 22, 1998, http://fas.org/irp/offdocs/pdd/pdd-63.htm, accessed 15 Jun 2015.

${ }^{4}$ Homeland Security Presidential Directive 7: Critical Infrastructure Identification, Prioritization, and Protection, December 17, 2003, https://www.whitehouse.gov/sites/default/files/omb/memoranda/fy04/m-04-15.pdf, accessed 15 Jun 2015. 
Transportation; and Water. Presidential Policy Directive 21 (PPD-21), Critical Infrastructure Security and Resilience,${ }^{5}$ has redefined the old sector taxonomy into 16 sectors. However, the publication of the new taxonomy has not yet been released; therefore, all statistics are reported based on the 18 sectors.

The purpose of this report is to analyze the IST data collected through the ECIP Initiative, identifying the prevalence of dependence upon electric power across the collected critical infrastructure data, as well as the types of mitigation measures facilities typically have in place, specifically internal generation capabilities, backup generation, and uninterrupted power sources, as well as the purpose and duration of these mitigation measures. Section 2 explains how facilities are grouped for statistical analysis; Section 3 explores the extent of electric dependence for these groups of facilities; Section 4 investigates mitigation measures for the study groups for the entire Nation; Section 5 investigates mitigation measures for facilities grouped by census region; and Section 6 concludes the report.

${ }^{5}$ Presidential Policy Directive 21, Critical Infrastructure Security and Resilience, February 12, 2013, https://www.whitehouse.gov/the-press-office/2013/02/12/presidential-policy-directive-critical-infrastructuresecurity-and-resil, accessed 23 Mar 2015. 


\section{Creating Facility Groupings for Analysis}

In the following sections, the IST data is analyzed by DHS Critical Infrastructure Sector within each census region. Where feasible, the analysis is conducted at a deeper level. The taxonomy breakout is as follows: sector, subsector, segment, sub-segment, and asset. An example in the Energy Sector would be: Energy, Electricity, Electricity Generation, Hydroelectric Power Generation, and Hydroelectric Dams.

Although each level is more specific than the previous, the group size gets smaller while progressing deeper into the taxonomy, and it is difficult to draw significant conclusions from statistics on a group with fewer than 30 entities. Therefore, the analysts only looked at groups that had 30 or more surveyed facilities within them. Groups that did not have more than 30 facilities were rolled up into the next higher level of the taxonomy. Table 1 shows the location of each group within the Critical Infrastructure Taxonomy, along with the number of facilities within each group. Note that the groups that had fewer than 30 facilities and could not be rolled up into another are annotated with an asterisk next to the number of facilities. These groups were removed from analysis due to the small sample size. 
Table 1: Groups within the Critical Infrastructure Taxonomy

\begin{tabular}{|c|c|c|c|c|c|}
\hline Sector & Subsector & Segment & Sub-segment & Asset & $\begin{array}{l}\text { No. of } \\
\text { Facilities }\end{array}$ \\
\hline \multicolumn{5}{|c|}{ Agriculture and Food } & 61 \\
\hline & \multicolumn{4}{|c|}{ Processing, Packaging and Production } & 43 \\
\hline \multicolumn{5}{|c|}{ Banking and Finance } & 31 \\
\hline & \multicolumn{4}{|c|}{ Banking and Credit } & 52 \\
\hline \multicolumn{5}{|c|}{ Chemical and Hazardous Materials Industry } & $16^{*}$ \\
\hline \multicolumn{5}{|c|}{ Commercial Facilities } & 49 \\
\hline & & \multicolumn{3}{|l|}{ Hotel or Motel } & 60 \\
\hline & \multicolumn{4}{|c|}{ Public Assembly } & 122 \\
\hline & & \multicolumn{3}{|l|}{ Arena } & 82 \\
\hline & & \multicolumn{3}{|c|}{ Community Organization Facility } & 47 \\
\hline & & \multicolumn{3}{|c|}{ Stadium } & 108 \\
\hline & \multicolumn{4}{|c|}{ Real Estate Facility } & 46 \\
\hline & & & Office Building - S & Alone & 43 \\
\hline & & \multicolumn{3}{|c|}{ 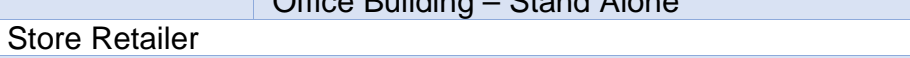 } & 33 \\
\hline \multicolumn{5}{|c|}{ Communications } & 54 \\
\hline \multicolumn{5}{|c|}{ Dams } & $11^{*}$ \\
\hline & \multicolumn{4}{|l|}{ Dam Project } & 34 \\
\hline & & \multicolumn{3}{|c|}{ Hydropower Plant } & 38 \\
\hline & & \multicolumn{3}{|c|}{ Water Retention Structure } & 37 \\
\hline \multicolumn{5}{|c|}{ Defense Industrial Base } & $26^{*}$ \\
\hline \multicolumn{5}{|c|}{ Emergency Services } & 52 \\
\hline & & \multicolumn{3}{|c|}{ Law Enforcement Administrative Office/Headquarters } & 32 \\
\hline \multicolumn{5}{|c|}{ 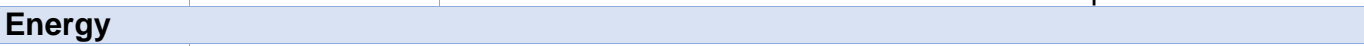 } & 39 \\
\hline & \multicolumn{4}{|l|}{ Electricity } & 33 \\
\hline & & & Distribution Substa & & 44 \\
\hline & & \multicolumn{3}{|c|}{ Electricity Generation } & 40 \\
\hline & & & & Coal Fired Generator & 31 \\
\hline & & \multicolumn{3}{|c|}{ Electricity Transmission } & 32 \\
\hline & & & Transmission Subs & & 114 \\
\hline & Petroleum & & & & 59 \\
\hline Governm & Facilities & & & & 47 \\
\hline & & Higher Educa & Facility & & 132 \\
\hline & & Pre-K-12 Sch & & & 318 \\
\hline & & & Office or Office Bu & g Complex & 66 \\
\hline & & & & Agency Headquarters & 51 \\
\hline & & & & $\begin{array}{l}\text { Judicial Chamber or } \\
\text { Office }\end{array}$ & 50 \\
\hline Health Ca & and Public $\mathrm{He}$ & & & & 58 \\
\hline & & Hospital & & & 53 \\
\hline & & & Critical Access Ho & & 33 \\
\hline & & & & $\begin{array}{l}\text { Private or Not-For- } \\
\text { Profit General } \\
\text { Medical and Surgical } \\
\text { Hospital }\end{array}$ & 131 \\
\hline & & & & $\begin{array}{l}\text { State, Local, or Tribal } \\
\text { General Medical and } \\
\text { Surgical Hospital }\end{array}$ & 34 \\
\hline & Health Suppo & Facility & & & 50 \\
\hline
\end{tabular}


Table 2: (Cont.)

\begin{tabular}{|c|c|c|c|c|c|}
\hline Sector & Subsector & Segment & Sub-segment & Asset & $\begin{array}{c}\text { No. of } \\
\text { Facilities }\end{array}$ \\
\hline \multicolumn{5}{|c|}{ Information Technology } & $15^{*}$ \\
\hline \multicolumn{5}{|c|}{ Manufacturing } & 35 \\
\hline \multicolumn{5}{|c|}{ National Monuments and Icons } & $4^{*}$ \\
\hline \multicolumn{5}{|c|}{ Nuclear Reactors, Materials, and Waste } & $5^{*}$ \\
\hline \multicolumn{5}{|c|}{ Postal and Shipping } & $1^{*}$ \\
\hline \multicolumn{5}{|c|}{ Transportation } & 47 \\
\hline & & \multicolumn{3}{|l|}{ Port } & 37 \\
\hline & \multicolumn{4}{|l|}{ Mass Transit } & 32 \\
\hline & \multicolumn{4}{|l|}{ Road } & 31 \\
\hline & & & Road Bridge & & 73 \\
\hline \multicolumn{5}{|l|}{ Water } & 99 \\
\hline & \multicolumn{4}{|c|}{ Wastewater Facility } & 36 \\
\hline & & \multicolumn{3}{|c|}{ Wastewater Treatment Plant } & 100 \\
\hline & \multicolumn{4}{|c|}{ Water Treatment Facility } & 167 \\
\hline
\end{tabular}

* Denotes group not included in analysis due to insufficient numbers

Table 2 expands upon Table 1. For each group, the table depicts the sector in which it belongs, the associated aggregate level of the taxonomy, and the number of facilities within that group. For example, the 61 Agriculture and Food facilities have been aggregated to the sector level, and can be any number of facility types, from Dairy Product Manufacturing (Except Frozen) to Grocery and Related Product Wholesalers. Conversely, Coal-fired Generators (31) could be grouped at the Asset level within the Energy sector. This table does not contain the groups with fewer than 30 facilities. The following analyses will focus on the 49 study groups in Table 2 .

Table 3: Forty-nine (49) Facility Groupings for Analysis

\begin{tabular}{|c|c|c|c|}
\hline Study Group Name & Sector & $\begin{array}{c}\text { Taxonomy } \\
\text { Level }\end{array}$ & No. Facilities \\
\hline Agriculture and Food & Agriculture and Food & Sector & 61 \\
\hline Banking and Finance & Banking and Finance & Sector & 31 \\
\hline Commercial Facilities & Commercial Facilities & Sector & 49 \\
\hline Communications & Communications & Sector & 54 \\
\hline Emergency Services & Emergency Services & Sector & 52 \\
\hline Energy & Energy & Sector & 39 \\
\hline Government Facilities & Government Facilities & Sector & 47 \\
\hline Healthcare and Public Health & Healthcare and Public Health & Sector & 58 \\
\hline Manufacturing & Manufacturing & Sector & 35 \\
\hline Transportation & Transportation & Sector & 47 \\
\hline Water & Water & Sector & 99 \\
\hline Processing, Packaging, and Production & Agriculture and Food & Subsector & 43 \\
\hline Banking and Credit & Banking and Finance & Subsector & 52 \\
\hline Public Assembly & Commercial Facilities & Subsector & 122 \\
\hline Real Estate Facility & Commercial Facilities & Subsector & 46 \\
\hline Dam Project & Dams & Subsector & 34 \\
\hline Electricity & Energy & Subsector & 33 \\
\hline
\end{tabular}


Table 4: (Cont.)

\begin{tabular}{|c|c|c|c|}
\hline Study Group Name & Sector & $\begin{array}{l}\text { Taxonomy } \\
\text { Level }\end{array}$ & No. Facilities \\
\hline Petroleum & Energy & Subsector & 59 \\
\hline Health Supporting Facility & Healthcare and Public Health & Subsector & 50 \\
\hline Mass Transit & Transportation & Subsector & 32 \\
\hline Road & Transportation & Subsector & 31 \\
\hline Wastewater Facility & Water & Subsector & 36 \\
\hline Water Treatment Facility & Water & Subsector & 167 \\
\hline Hotel or Motel & Commercial Facilities & Segment & 60 \\
\hline Arena & Commercial Facilities & Segment & 82 \\
\hline Community Organization Facility & Commercial Facilities & Segment & 47 \\
\hline Stadium & Commercial Facilities & Segment & 108 \\
\hline Store Retailer & Commercial Facilities & Segment & 33 \\
\hline Hydropower Plant & Energy & Segment & 38 \\
\hline Water Retention Structure & Dams & Segment & 37 \\
\hline $\begin{array}{l}\text { Law Enforcement Administrative } \\
\text { Office/Headquarters }\end{array}$ & Emergency Services & Segment & 32 \\
\hline Electricity Generation & Energy & Segment & 40 \\
\hline Electricity Transmission & Energy & Segment & 32 \\
\hline Higher Education Facility & Government Facilities & Segment & 132 \\
\hline Pre-K-12 School & Government Facilities & Segment & 318 \\
\hline Hospital & Healthcare and Public Health & Segment & 53 \\
\hline Port & Transportation & Segment & 37 \\
\hline Wastewater Treatment Plant & Water & Segment & 100 \\
\hline Office Building - Stand Alone & Commercial Facilities & Subsegment & 43 \\
\hline Distribution Substation & Energy & Subsegment & 44 \\
\hline Transmission Substation & Energy & Subsegment & 114 \\
\hline Office or Office Building Complex & Government Facilities & Subsegment & 66 \\
\hline Critical Access Hospital & Healthcare and Public Health & Subsegment & 33 \\
\hline Road Bridge & Transportation & Subsegment & 73 \\
\hline Coal-fired Generator & Energy & Asset & 31 \\
\hline Agency Headquarters & Government Facilities & Asset & 51 \\
\hline Judicial Chamber or Office & Government Facilities & Asset & 50 \\
\hline $\begin{array}{l}\text { Private or Private Not-for-Profit General } \\
\text { Medical and Surgical Hospital }\end{array}$ & Healthcare and Public Health & Asset & 131 \\
\hline $\begin{array}{l}\text { State, Local, or Tribal General Medical } \\
\text { and Surgical Hospital }\end{array}$ & Healthcare and Public Health & Asset & 34 \\
\hline
\end{tabular}




\section{External Electric Power Dependence}

Using the study groups listed in Table 2, Table 3 shows the percentage of facilities within each study group that is dependent on external electrical power. Within the construct of the survey, a facility is dependent upon electric power if it requires an external source of electricity for its core operations. If a facility answers "no," it is either because it does not rely on electricity for core operations or it generates its own electricity and does not rely on an outside source. The data collection method does not distinguish between the two. Of the surveyed facilities, most rely heavily on an external source of electric power. Exceptions are some energy assets (substations and electric generation and transmission facilities), and some transportation assets (road bridges). These are indicated in Table 3.

Table 5: Facilities that Depend on External Electrical Power by Study Group

\begin{tabular}{|c|c|}
\hline Study Group Name & Percent (\%) \\
\hline Agriculture and Food & 100 \\
\hline Banking and Finance & 100 \\
\hline Commercial Facilities & 100 \\
\hline Communications & 100 \\
\hline Emergency Services & 100 \\
\hline Energy & 100 \\
\hline Government Facilities & 100 \\
\hline Healthcare and Public Health & 100 \\
\hline Manufacturing & 100 \\
\hline Transportation & 85 \\
\hline Water & 95 \\
\hline Processing, Packaging, and Production & 100 \\
\hline Banking and Credit & 100 \\
\hline Public Assembly & 99 \\
\hline Real Estate Facility & 100 \\
\hline Dam Project & 79 \\
\hline Electricity & 79 \\
\hline Petroleum & 98 \\
\hline Health Supporting Facility & 100 \\
\hline Mass Transit & 100 \\
\hline Road & 94 \\
\hline Wastewater Facility & 97 \\
\hline Water Treatment Facility & 100 \\
\hline Hotel or Motel & 100 \\
\hline Arena & 100 \\
\hline Community Organization Facility & 100 \\
\hline Stadium & 99 \\
\hline Store Retailer & 100 \\
\hline Hydropower Plant & 79 \\
\hline Water Retention Structure & 84 \\
\hline Law Enforcement Administrative Office/Headquarters & 100 \\
\hline Electricity Generation & $63^{*}$ \\
\hline Electricity Transmission & $69^{*}$ \\
\hline Higher Education Facility & 100 \\
\hline Pre K - 12 School & 100 \\
\hline
\end{tabular}


Table 6: (Cont.)

\begin{tabular}{|c|c|}
\hline Study Group Name & Percent (\%) \\
\hline Hospital & 100 \\
\hline Port & 97 \\
\hline Wastewater Treatment Plant & 98 \\
\hline Office Building - Stand Alone & 100 \\
\hline Distribution Substation & $25^{\star}$ \\
\hline Transmission Substation & $32 *$ \\
\hline Office or Office Building Complex & 100 \\
\hline Critical Access Hospital & 100 \\
\hline Road Bridge & $26^{\star}$ \\
\hline Coal-fired Generator & $68^{*}$ \\
\hline Agency Headquarters & 100 \\
\hline Judicial Chamber or Office & 100 \\
\hline Private or Private Not-for-Profit General Medical and Surgical Hospital & 100 \\
\hline State, Local, or Tribal General Medical and Surgical Hospital & 100 \\
\hline
\end{tabular}

* Denotes groups that do not rely heavily on an external source of electric power. 


\section{External Electric Power Mitigation Measures}

Facilities that rely on external electric power often have measures in place to mitigate against electrical power loss. The survey collects information on two types of mitigation measures: (1) an internal source of power, such as an onsite power plant or cogeneration plant, and (2) an alternate or backup, such as a backup generator or an uninterrupted power system (UPS). The mitigation measures a facility will employ are determined through a number of factors including region, regulations, climate, politics, facility function, or economic considerations.

Table 4 details mitigation measures for the study groups that depend upon an external source of power. The columns in the table provide information on the percentage within the 49 study groups that have an internal electric power source, an alternate or backup, or both. The final column captures the percentage of facilities with neither an internal electric power source nor an alternate or backup, indicating they have no physical backup measures for the loss of electric power. $^{6}$

Table 7: Facility Mitigation Measures by Group

\begin{tabular}{|c|c|c|c|c|}
\hline Study Group Name & $\begin{array}{l}\text { Percentage } \\
(\%) \text { with } \\
\text { Internal } \\
\text { Electric } \\
\text { Power Source }\end{array}$ & $\begin{array}{c}\text { Percentage } \\
(\%) \text { with an } \\
\text { Alternate or } \\
\text { Backup }\end{array}$ & $\begin{array}{l}\text { Percentage (\%) } \\
\text { with Internal } \\
\text { Power and an } \\
\text { Alternate or } \\
\text { Backup }\end{array}$ & $\begin{array}{l}\text { Percentage } \\
(\%) \text { with } \\
\text { Neither } \\
\text { Mitigation } \\
\text { Measure }\end{array}$ \\
\hline Agriculture and Food & 2 & 64 & 2 & 36 \\
\hline Banking and Finance & 0 & 100 & 0 & 0 \\
\hline Commercial Facilities & 6 & 96 & 6 & 4 \\
\hline Communications & 2 & 98 & 2 & 2 \\
\hline Emergency Services & 0 & 94 & 0 & 6 \\
\hline Energy & 5 & 72 & 5 & 28 \\
\hline Government Facilities & 2 & 85 & 2 & 15 \\
\hline Healthcare and Public Health & 2 & 83 & 2 & 17 \\
\hline Manufacturing & 9 & 74 & 9 & 26 \\
\hline Transportation & 3 & 93 & 3 & 8 \\
\hline Water & 2 & 80 & 2 & 20 \\
\hline Processing, Packaging, and Production & 12 & 58 & 9 & 40 \\
\hline Banking and Credit & 2 & 87 & 2 & 14 \\
\hline Public Assembly & 4 & 92 & 4 & 8 \\
\hline Real Estate Facility & 4 & 89 & 4 & 11 \\
\hline Dam Project & 4 & 93 & 4 & 7 \\
\hline Electricity & 8 & 96 & 8 & 4 \\
\hline Petroleum & 3 & 67 & 2 & 31 \\
\hline Health Supporting Facility & 10 & 88 & 10 & 12 \\
\hline Mass Transit & 0 & 72 & 0 & 28 \\
\hline Road & 0 & 93 & 0 & 7 \\
\hline Wastewater Facility & 3 & 71 & 3 & 29 \\
\hline Water Treatment Facility & 4 & 89 & 4 & 11 \\
\hline
\end{tabular}

\footnotetext{
${ }^{6}$ Facilities could still participate in priority restoration plans and/or have established contingency plans with their service provider.
} 
Table 8: (Cont.)

\begin{tabular}{|c|c|c|c|c|}
\hline Study Group Name & $\begin{array}{c}\text { Percentage } \\
\text { with Internal } \\
\text { Electric } \\
\text { Power Source }\end{array}$ & $\begin{array}{l}\text { Percentage } \\
\text { with an } \\
\text { Alternate or } \\
\text { Backup }\end{array}$ & $\begin{array}{l}\text { Percentage with } \\
\text { Internal Power } \\
\text { and an } \\
\text { Alternate or } \\
\text { Backup }\end{array}$ & $\begin{array}{c}\text { Percentage } \\
\text { with Neither } \\
\text { Mitigation } \\
\text { Measure }\end{array}$ \\
\hline Hotel or Motel & 2 & 97 & 2 & 3 \\
\hline Arena & 5 & 94 & 5 & 6 \\
\hline Community Organization Facility & 0 & 32 & 0 & 68 \\
\hline Stadium & 7 & 80 & 6 & 19 \\
\hline Store Retailer & 3 & 88 & 3 & 12 \\
\hline Hydropower Plant & 63 & 97 & 63 & 3 \\
\hline Water Retention Structure & 3 & 90 & 3 & 10 \\
\hline $\begin{array}{l}\text { Law Enforcement Administrative } \\
\text { Office/Headquarters }\end{array}$ & 0 & 97 & 0 & 3 \\
\hline Electricity Generation & 52 & 88 & 48 & 8 \\
\hline Electricity Transmission & 5 & 91 & 5 & 9 \\
\hline Higher Education Facility & 7 & 71 & 7 & 28 \\
\hline Pre-K-12 School & 1 & 43 & 0 & 57 \\
\hline Hospital & 2 & 98 & 2 & 2 \\
\hline Port & 3 & 69 & 3 & 31 \\
\hline Wastewater Treatment Plant & 13 & 86 & 12 & 13 \\
\hline Office Building - Stand Alone & 2 & 93 & 2 & 7 \\
\hline Distribution Substation & 9 & 64 & 9 & 36 \\
\hline Transmission Substation & 0 & 58 & 0 & 42 \\
\hline Office or Office Building Complex & 8 & 77 & 8 & 23 \\
\hline Critical Access Hospital & 0 & 100 & 0 & 0 \\
\hline Road Bridge & 0 & 90 & 0 & 11 \\
\hline Coal-fired Generator & 91 & 71 & 62 & 0 \\
\hline Agency Headquarters & 12 & 77 & 12 & 24 \\
\hline Judicial Chamber or Office & 0 & 82 & 0 & 18 \\
\hline $\begin{array}{l}\text { Private or Private Not-for-Profit General } \\
\text { Medical and Surgical Hospital }\end{array}$ & 8 & 100 & 8 & 0 \\
\hline $\begin{array}{l}\text { State, Local, or Tribal General Medical } \\
\text { and Surgical Hospital }\end{array}$ & 6 & 100 & 6 & 0 \\
\hline
\end{tabular}

Initial analysis shows that almost 80 percent of the facilities that rely on external electric power have some kind of mitigation system in place, with the overwhelming majority of those having an alternate or backup. It also appears that facilities that support emergency response or provide a critical service are more likely to have some type of mitigation measure in place, whether that be internal generation, an alternate or backup, or both. For example, public health (i.e., hospitals), emergency services, and communication facilities tend to have some backup generation capability. As additional lifeline facilities are evaluated, similar insights might be realized with more data. 


\subsection{Internal Electric Generation Capability}

One of the ways a facility can mitigate external power loss is by having the ability to generate electrical power onsite. The two primary methods for providing this power are an onsite power plant and a cogeneration facility. Approximately 5 percent of surveyed facilities that are dependent on an external source of electricity have internal electric power generation capabilities. $^{7}$

Even if a facility has an internal power source, it may be unable to sustain the entire facility load. Of the facilities with an internal power source, 67 percent stated internal generation could sustain the full facility load. The remaining 33 percent could, on average, sustain 40 percent of the peak facility demand. Table 5 contains information on the number of facilities within each study group that have an internal power source, as well as the average percentage of the full facility load that can be sustained by that internal source.

Table 9: Internal Electric Generation Capability

\begin{tabular}{|c|c|c|}
\hline Study Group Name & $\begin{array}{l}\text { Number of Facilities } \\
\text { with Internal } \\
\text { Generation }\end{array}$ & $\begin{array}{l}\text { Average Percent (\%) of Full } \\
\text { Facility Load Supplied by } \\
\text { Internal Generation }\end{array}$ \\
\hline Agriculture and Food & 1 & 0 \\
\hline \multicolumn{3}{|l|}{ Banking and Finance } \\
\hline Commercial Facilities & 3 & 33 \\
\hline Communications & 1 & 100 \\
\hline \multicolumn{3}{|l|}{ Emergency Services } \\
\hline Energy & 2 & 100 \\
\hline Government Facilities & 1 & 100 \\
\hline Healthcare and Public Health & 1 & 100 \\
\hline Manufacturing & 3 & 33 \\
\hline Transportation & 1 & 0 \\
\hline Water & 2 & 100 \\
\hline Processing, Packaging, and Production & 5 & 80 \\
\hline Banking and Credit & 1 & 100 \\
\hline Public Assembly & 5 & 60 \\
\hline Real Estate Facility & 2 & 0 \\
\hline Dam Project & 1 & 100 \\
\hline Electricity & 2 & 50 \\
\hline Petroleum & 2 & 0 \\
\hline Health Supporting Facility & 5 & 60 \\
\hline \multicolumn{3}{|l|}{ Mass Transit } \\
\hline \multicolumn{3}{|l|}{ Road } \\
\hline Wastewater Facility & 1 & 0 \\
\hline Water Treatment Facility & 7 & 57 \\
\hline Hotel or Motel & 1 & 0 \\
\hline Arena & 4 & 50 \\
\hline \multicolumn{3}{|l|}{ Community Organization Facility } \\
\hline Stadium & 7 & 86 \\
\hline
\end{tabular}

7 Of these facilities, 60 percent had an onsite power plant and 40 percent had a cogeneration unit. 
Table 10: (Cont.)

\begin{tabular}{|c|c|c|}
\hline Study Group Name & $\begin{array}{l}\text { Number of Facilities } \\
\text { with Internal } \\
\text { Generation }\end{array}$ & $\begin{array}{l}\text { Average Percent (\%) of Ful } \\
\text { Facility Load Supplied by } \\
\text { Internal Generation }\end{array}$ \\
\hline Store Retailer & 1 & 0 \\
\hline Hydropower Plant & 19 & 100 \\
\hline Water Retention Structure & 1 & 0 \\
\hline \multicolumn{3}{|l|}{$\begin{array}{l}\text { Law Enforcement Administrative } \\
\text { Office/Headquarters }\end{array}$} \\
\hline Electricity Generation & 13 & 100 \\
\hline Electricity Transmission & 1 & 100 \\
\hline Higher Education Facility & 10 & 30 \\
\hline Pre-K-12 School & 3 & 33 \\
\hline Hospital & 1 & 100 \\
\hline Port & 1 & 0 \\
\hline Wastewater Treatment Plant & 13 & 39 \\
\hline Office Building - Stand Alone & 1 & 0 \\
\hline Distribution Substation & 1 & 100 \\
\hline \multicolumn{3}{|l|}{ Transmission Substation } \\
\hline Office or Office Building Complex & 5 & 80 \\
\hline \multicolumn{3}{|l|}{ Critical Access Hospital } \\
\hline \multicolumn{3}{|l|}{ Road Bridge } \\
\hline Coal-fired Generator & 19 & 95 \\
\hline Agency Headquarters & 6 & 83 \\
\hline \multicolumn{3}{|l|}{ Judicial Chamber or Office } \\
\hline $\begin{array}{l}\text { Private or Private Not-for-Profit General Medical } \\
\text { and Surgical Hospital }\end{array}$ & 10 & 40 \\
\hline $\begin{array}{l}\text { State, Local, or Tribal General Medical and } \\
\text { Surgical Hospital }\end{array}$ & 2 & 100 \\
\hline
\end{tabular}

Due to small numbers of facilities with internal generation capabilities, only three of the 49 study groups had enough information on facility load capacity to understand the distribution of load capacity. These study groups were Higher Education Facility (7 facilities), Wastewater Treatment Plants (8 facilities), and Private or Private Not-for-Profit General Medical and Surgical Hospital (6 facilities). The boxplots in Figure 1 detail the distribution of percent of full facility load for the Higher Education Facility Group and the Wastewater Treatment Plants Group. Of the six Private Hospitals with less than full facility load capability, four of them could sustain 75 percent, one could sustain 80 percent, and the other one only 30 percent; therefore, a boxplot would not sufficiently describe the data.

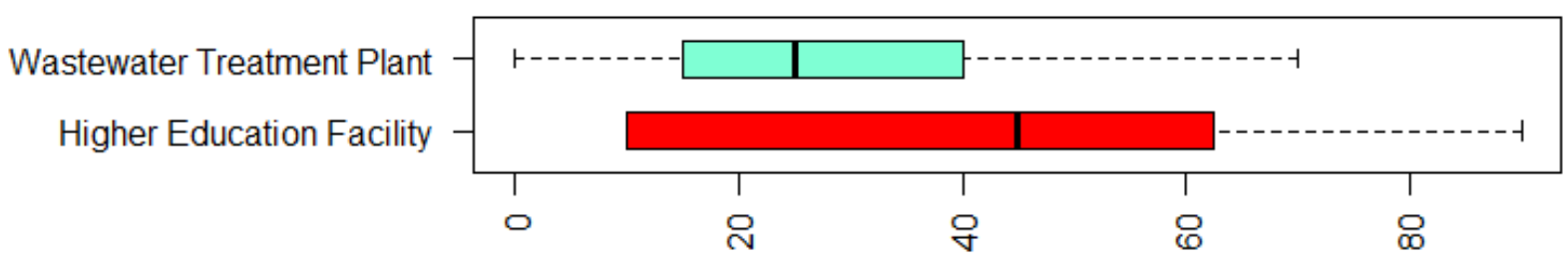

Percent of Full Facility Load

Figure 1: Distribution of Load Capacity for Facilities with Less than Full Facility Load Internal Generation Capability 


\subsection{Backup Electric Generation Capability}

The existence of an alternate source of power or backup generation capacity is more common among the study groups than are internal generation capabilities; 80 percent of the facilities that require external electrical power had an alternate or backup. An alternate source of power can be anything from steam to windmills to solar arrays. For the purposes of the survey, a backup capability is either a backup generator and/or UPS. Table 6 presents the percentage of those facilities in the 49 study groups with a backup generator, a UPS, or both. The survey does not explicitly collect types of alternate sources; therefore, the analysis does not include that variable.

Table 11: Facilities with an Alternate or Backup

\begin{tabular}{|c|c|c|c|}
\hline Study Group Name & $\begin{array}{l}\text { Percentage (\%) } \\
\text { with a Backup } \\
\text { Generator }\end{array}$ & $\begin{array}{l}\text { Percentage (\%) } \\
\text { with a UPS }\end{array}$ & $\begin{array}{c}\text { Percentage (\%) with } \\
\text { a Backup Generator } \\
\text { and UPS }\end{array}$ \\
\hline Agriculture and Food & 64 & 41 & 41 \\
\hline Banking and Finance & 100 & 97 & 97 \\
\hline Commercial Facilities & 94 & 82 & 80 \\
\hline Communications & 98 & 98 & 98 \\
\hline Emergency Services & 94 & 71 & 71 \\
\hline Energy & 72 & 49 & 49 \\
\hline Government Facilities & 83 & 55 & 53 \\
\hline Healthcare and Public Health & 81 & 64 & 62 \\
\hline Manufacturing & 74 & 66 & 66 \\
\hline Transportation & 93 & 58 & 58 \\
\hline Water & 79 & 61 & 60 \\
\hline Processing, Packaging, and Production & 49 & 33 & 23 \\
\hline Banking and Credit & 87 & 75 & 75 \\
\hline Public Assembly & 88 & 62 & 59 \\
\hline Real Estate Facility & 87 & 48 & 46 \\
\hline Dam Project & 89 & 52 & 48 \\
\hline Electricity & 96 & 92 & 92 \\
\hline Petroleum & 62 & 55 & 50 \\
\hline Health Supporting Facility & 88 & 64 & 64 \\
\hline Mass Transit & 72 & 50 & 50 \\
\hline Road & 86 & 86 & 79 \\
\hline Wastewater Facility & 71 & 54 & 54 \\
\hline Water Treatment Facility & 88 & 72 & 71 \\
\hline Hotel or Motel & 97 & 65 & 65 \\
\hline Arena & 92 & 50 & 49 \\
\hline Community Organization Facility & 23 & 21 & 15 \\
\hline Stadium & 80 & 49 & 49 \\
\hline Store Retailer & 85 & 49 & 49 \\
\hline Hydropower Plant & 97 & 70 & 70 \\
\hline Water Retention Structure & 87 & 52 & 48 \\
\hline $\begin{array}{l}\text { Law Enforcement Administrative } \\
\text { Office/Headquarters }\end{array}$ & 97 & 75 & 75 \\
\hline Electricity Generation & 80 & 72 & 64 \\
\hline Electricity Transmission & 91 & 86 & 86 \\
\hline Higher Education Facility & 69 & 39 & 36 \\
\hline Pre-K-12 School & 37 & 24 & 19 \\
\hline Hospital & 98 & 77 & 77 \\
\hline Port & 61 & 31 & 22 \\
\hline Wastewater Treatment Plant & 85 & 56 & 55 \\
\hline Office Building - Stand Alone & 88 & 72 & 67 \\
\hline
\end{tabular}


Table 12: (Cont.)

\begin{tabular}{|l|c|c|c|}
\hline \multicolumn{1}{|c|}{$\begin{array}{c}\text { Study Group Name } \\
\text { Distribution Substation }\end{array}$} & $\begin{array}{c}\text { Percentage (\%) } \\
\text { with a Backup } \\
\text { Generator }\end{array}$ & $\begin{array}{c}\text { Percentage (\%) } \\
\text { with a UPS }\end{array}$ & $\begin{array}{c}\text { Percentage (\%) with } \\
\text { a Backup Generator } \\
\text { and UPS }\end{array}$ \\
\hline Transmission Substation & 46 & 55 & 36 \\
\hline Office or Office Building Complex & 44 & 58 & 44 \\
\hline Critical Access Hospital & 71 & 62 & 56 \\
\hline Road Bridge & 100 & 67 & 67 \\
\hline Coal-fired Generator & 90 & 58 & 58 \\
\hline Agency Headquarters & 62 & 62 & 62 \\
\hline Judicial Chamber or Office & 77 & 51 & 51 \\
\hline $\begin{array}{l}\text { Private or Private Not-for-Profit General } \\
\text { Medical and Surgical Hospital }\end{array}$ & 76 & 56 & 50 \\
\hline State, Local, or Tribal General Medical and & 100 & 86 & 86 \\
\hline Surgical Hospital & 100 & 77 & 77 \\
\hline
\end{tabular}

\subsection{Backup Generators}

A variety of factors are collected within the survey tool related to backup generator characteristics such as duration, fuel type, and primary purpose of the generator. The facility operators report backup generation duration before considering any refueling options. The duration numbers represent only the fuel that is onsite and readily available to use. The analyses for each of these characteristics are provided in the following sections.

\subsubsection{Backup Generator Duration}

Initial analysis shows that roughly 70 percent of the backup generators could provide power to the facility for more than 24 hours, and only 22 percent of them could provide power for more than 5 days. Table 7 details the distribution of the backup generator's duration of power for facilities in all study groups. Figure 2 is a boxplot displaying the distribution of backup generator duration. Due to the wide variety of times a backup generator could last, the $x$-axis in the boxplots is presented in log time (hours). Note that there is no boxplot for the facilities with a backup generator duration of 30 days or more, due to the highly skewed data within this range; 85 percent of these facilities could provide electrical power indefinitely (collected in the survey as a duration of 365 days). Only 4 percent of these facilities had a backup generator duration lasting between 3 and 6 months, and 11 percent had a duration lasting between 1 and 3 months.

Table 13: Backup Generator Duration

\begin{tabular}{|l|c|}
\hline $\begin{array}{c}\text { Duration of Backup Electrical } \\
\text { Generator Power }\end{array}$ & $\begin{array}{c}\text { Percentage (\%) } \\
\text { of Facilities }\end{array}$ \\
\hline More than 1 Month (>720 Hours) & 5 \\
\hline 5 Days to 1 Month (120 to 720 Hours) & 17 \\
\hline 1 to 5 Days (24 to 120 Hours) & 49 \\
\hline Less than 1 Day (15 Minutes to 24 Hours) & 29 \\
\hline
\end{tabular}




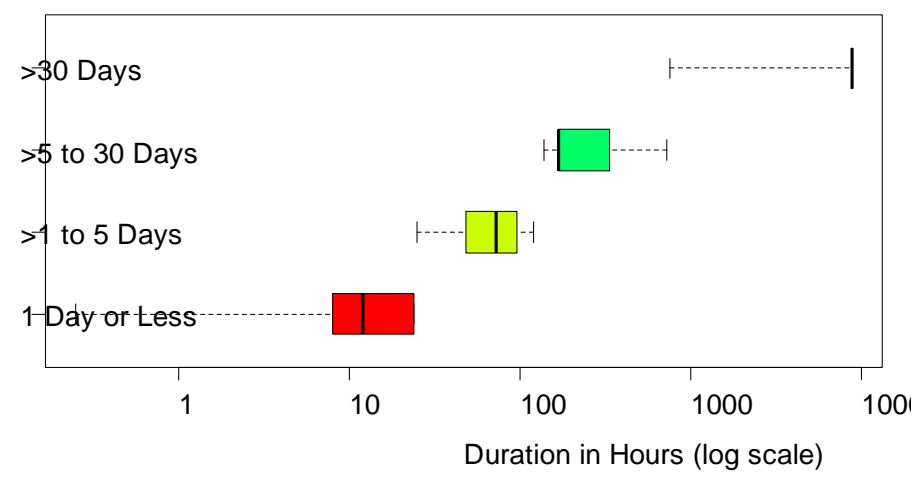

Figure 2: Distributions of Backup Generator Duration

The average backup generator duration was about 490 hours, or approximately 20 days; however, this average does not accurately portray the backup generator capability across the facilities due to the highly skewed data, as stated above. Another measure of central tendency, the median, revealed a duration of 72 hours, because the median is not as sensitive to extreme outliers. Because more than 75 percent of facilities report a backup duration of 5 days or less, the median appears to be the most accurate reflection of central tendency for these facilities.

\subsubsection{Backup Generator Fuel Type}

Duration of backup cannot be considered without consideration of the fuel source. The survey tool provides four options for type of fuel for backup generators: natural gas, propane, diesel, or other. Statistics on the "Other" category are not reported here, because no further information is collected on the types of "Other." Natural gas generators provide the longest duration (mean of 143 days), then propane (mean of 11 days), then diesel (mean of 5 days). Table 8 shows the percentage of all facilities with a backup generator that use a particular fuel type, along with the average duration of power, and Figure 3 shows a boxplot detailing the distribution of backup generator duration for each fuel type. Once again, the $x$-axis uses a logarithmic scale, due to the wide range of times.

Table 14: Backup Generator Fuel Type

\begin{tabular}{|l|c|c|}
$\begin{array}{l}\text { Generator } \\
\text { Fuel Type }\end{array}$ & $\begin{array}{c}\text { Percentage } \\
\text { (\%) of } \\
\text { Facilities }\end{array}$ & $\begin{array}{c}\text { Average } \\
\text { Duration } \\
\text { (in Hours) }\end{array}$ \\
\hline Propane & 4 & 274 \\
\hline Natural Gas & 10 & 3,449 \\
\hline Diesel & 85 & 112 \\
\hline
\end{tabular}




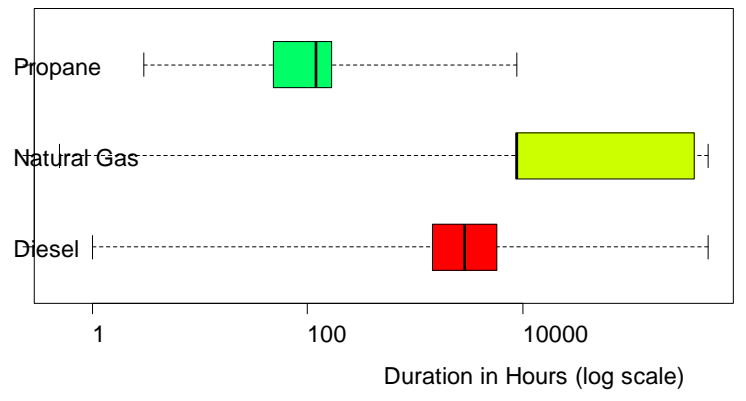

Figure 3: Duration of Backup Generator by Fuel Type

Table 9 expands upon this information, investigating, by study group, the typical type of fuel used, as well as the average duration of that type of generator. As shown in Table 8, 85 percent of facilities use a diesel generator, which provides the shortest duration of power. Note that the upper duration for the natural gas generators is imposed by the structure of the responses to the survey; in principle, there is no duration limit for this technology.

Table 15: Percentage of Facilities with a Backup Generator That Use Each Type of Fuel

\begin{tabular}{|c|c|c|c|c|c|c|}
\hline \multirow[b]{2}{*}{ Group Name } & \multicolumn{2}{|c|}{ Diesel } & \multicolumn{2}{|c|}{ Natural Gas } & \multicolumn{2}{|c|}{ Propane } \\
\hline & $\begin{array}{l}\text { Facilities } \\
(\%)\end{array}$ & $\begin{array}{c}\text { Average } \\
\text { Duration } \\
\text { (hours) }\end{array}$ & $\begin{array}{l}\text { Facilities } \\
\text { (\%) }\end{array}$ & $\begin{array}{c}\text { Average } \\
\text { Duration } \\
\text { (hours) }\end{array}$ & $\begin{array}{l}\text { Facilities } \\
(\%)\end{array}$ & $\begin{array}{l}\text { Average } \\
\text { Duration } \\
\text { (hours) }\end{array}$ \\
\hline Agriculture and Food & 74 & 90 & 23 & 3,005 & 3 & 120 \\
\hline Banking and Finance & 97 & 97 & 3 & 0 & 0 & N/A \\
\hline Commercial Facilities & 94 & 87 & 4 & 0 & 2 & 48 \\
\hline Communications & 83 & 185 & 0 & N/A & 17 & 263 \\
\hline Emergency Services & 88 & 142 & 8 & 6,750 & 4 & 99 \\
\hline Energy & 74 & 126 & 22 & 1,460 & 4 & 48 \\
\hline Government Facilities & 84 & 83 & 11 & 2,370 & 5 & 228 \\
\hline Healthcare and Public Health & 83 & 93 & 13 & 2,928 & 4 & 360 \\
\hline Manufacturing & 62 & 40 & 35 & 973 & 4 & 72 \\
\hline Transportation & 89 & 222 & 3 & 168 & 8 & 24 \\
\hline Water & 88 & 108 & 3 & N/A & 10 & 103 \\
\hline $\begin{array}{l}\text { Processing, Packaging, and } \\
\text { Production }\end{array}$ & 62 & 55 & 33 & 3,778 & 5 & 336 \\
\hline Banking and Credit & 96 & 107 & 4 & 0 & 0 & $\mathrm{~N} / \mathrm{A}$ \\
\hline Public Assembly & 86 & 62 & 13 & 782 & 1 & 24 \\
\hline Real Estate Facility & 90 & 77 & 10 & 0 & 0 & $\mathrm{~N} / \mathrm{A}$ \\
\hline Dam Project & 75 & 129 & 0 & $N / A$ & 25 & 847 \\
\hline Electricity & 79 & 65 & 21 & 1,752 & 0 & $\mathrm{~N} / \mathrm{A}$ \\
\hline Petroleum & 53 & 24 & 3 & 720 & 44 & 53 \\
\hline Health Supporting Facility & 93 & 88 & 7 & 40 & 0 & $\mathrm{~N} / \mathrm{A}$ \\
\hline Mass Transit & 83 & 1,432 & 17 & 6,540 & 0 & N/A \\
\hline Road & 80 & 145 & 12 & 2,920 & 8 & 132 \\
\hline Wastewater Facility & 96 & 62 & 4 & 0 & 0 & $\mathrm{~N} / \mathrm{A}$ \\
\hline Water Treatment Facility & 88 & 96 & 10 & 2,931 & 2 & 40 \\
\hline Hotel or Motel & 88 & 73 & 9 & 1,759 & 3 & 362 \\
\hline Arena & 96 & 41 & 4 & 32 & 0 & $\mathrm{~N} / \mathrm{A}$ \\
\hline Community Organization Facility & 82 & 72 & 18 & 4,380 & 0 & $\mathrm{~N} / \mathrm{A}$ \\
\hline Stadium & 90 & 23 & 11 & 2,920 & 0 & N/A \\
\hline
\end{tabular}


Table 16: (Cont.)

\begin{tabular}{|c|c|c|c|c|c|c|}
\hline \multirow[b]{2}{*}{ Group Name } & \multicolumn{2}{|c|}{ Diesel } & \multicolumn{2}{|c|}{ Natural Gas } & \multicolumn{2}{|c|}{ Propane } \\
\hline & $\begin{array}{l}\text { Facilities } \\
(\%)\end{array}$ & $\begin{array}{l}\text { Average } \\
\text { Duration } \\
\text { (hours) }\end{array}$ & $\begin{array}{l}\text { Facilities } \\
(\%)\end{array}$ & $\begin{array}{l}\text { Average } \\
\text { Duration } \\
\text { (hours) }\end{array}$ & $\begin{array}{l}\text { Facilities } \\
(\%)\end{array}$ & $\begin{array}{l}\text { Average } \\
\text { Duration } \\
\text { (hours) }\end{array}$ \\
\hline Store Retailer & 93 & 36 & 7 & 4,380 & 0 & $\mathrm{~N} / \mathrm{A}$ \\
\hline Hydropower Plant & 93 & 115 & 0 & N/A & 7 & 144 \\
\hline Water Retention Structure & 89 & 427 & 0 & N/A & 11 & 112 \\
\hline $\begin{array}{l}\text { Law Enforcement Administrative } \\
\text { Office/Headquarters }\end{array}$ & 90 & 86 & 10 & 27 & 0 & N/A \\
\hline Electricity Generation & 60 & 46 & 20 & 2,190 & 20 & 114 \\
\hline Electricity Transmission & 100 & 133 & 0 & N/A & 0 & N/A \\
\hline Higher Education Facility & 74 & 81 & 20 & 3,973 & 7 & 80 \\
\hline Pre-K-12 School & 59 & 62 & 36 & 6,342 & 5 & 1,657 \\
\hline Hospital & 96 & 127 & 4 & 0 & 0 & N/A \\
\hline Port & 91 & 64 & 9 & 4,380 & 0 & N/A \\
\hline Wastewater Treatment Plant & 95 & 88 & 4 & 5,840 & 1 & 48 \\
\hline Office Building - Stand Alone & 97 & 70 & 3 & 0 & 0 & N/A \\
\hline Distribution Substation & 80 & 99 & 20 & 0 & 0 & N/A \\
\hline Transmission Substation & 94 & 92 & 6 & 2,376 & 0 & N/A \\
\hline Office or Office Building Complex & 87 & 52 & 9 & 8,760 & 4 & 64 \\
\hline Critical Access Hospital & 97 & 78 & 3 & 0 & 0 & N/A \\
\hline Road Bridge & 94 & 140 & 6 & 8,760 & 0 & N/A \\
\hline Coal-fired Generator & 83 & 956 & 17 & 4,380 & 0 & N/A \\
\hline Agency Headquarters & 77 & 65 & 21 & 3,825 & 3 & 48 \\
\hline Judicial Chamber or Office & 87 & 64 & 14 & 5,270 & 0 & N/A \\
\hline $\begin{array}{l}\text { Private or Private Not-for-Profit } \\
\text { General Medical and Surgical } \\
\text { Hospital }\end{array}$ & 99 & 112 & 2 & 4,428 & 0 & N/A \\
\hline $\begin{array}{l}\text { State, Local, or Tribal General } \\
\text { Medical and Surgical Hospital }\end{array}$ & 100 & 154 & 0 & N/A & 0 & N/A \\
\hline
\end{tabular}

The percentage of facilities using natural gas generators within each study group spans a range of 0 percent to 36 percent, as depicted in Figure 4. Focusing on the right-hand side of the graph, it can be seen that those types of facilities most likely to have a natural gas generator are linked to some type of emergency response, community wellness, or electric generation and distribution. The circle sizes also correspond to the percentage of each group's facilities that has natural gas generators.

In addition to the type and fuel used for the backup generators, facility owners and operators were also asked about the purpose of the generator. The options provided are as follows:

- Full Facility Load: The generator supports the full facility load. There is no loss of facility functionality.

- Core Operations: Allows the essential and core functions of a facility to continue, while non-essential functions are discontinued. Facility operates in a degraded state.

- Graceful Shutdown: Allows time to shut down processes in a safe and efficient manner without causing a disaster internally or externally. 
- Life Safety: The exit lights stay lit, emergency doors open and necessary alarms still work, allowing facility occupants to safely evacuate. Core functions may or may not still operate.

Figure 5 shows the percentage of backup generators used for each purpose.

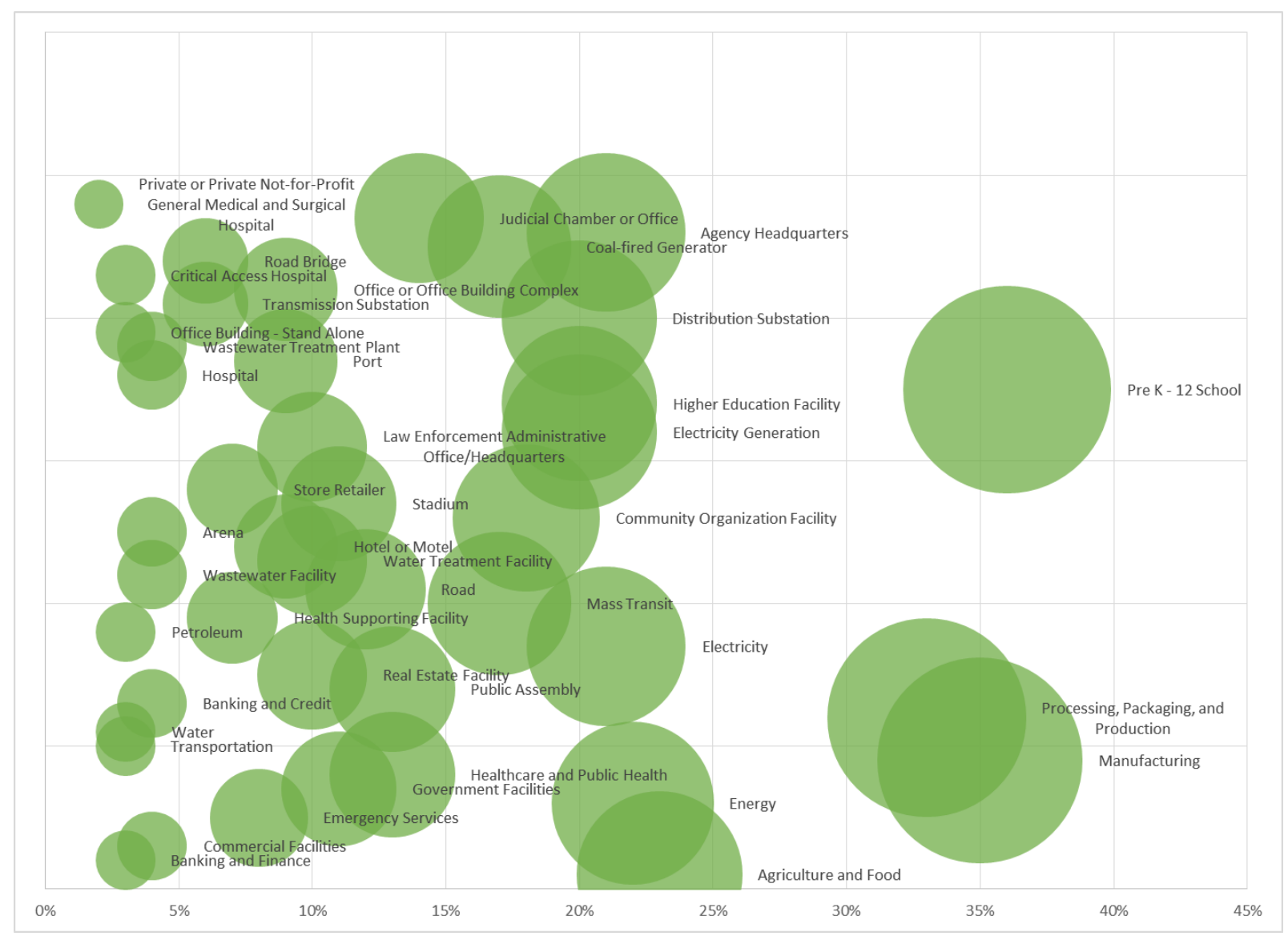

Figure 4: Percent of Facilities, by Study Group, with Natural Gas Backup Generators 
Backup Generators By Purpose

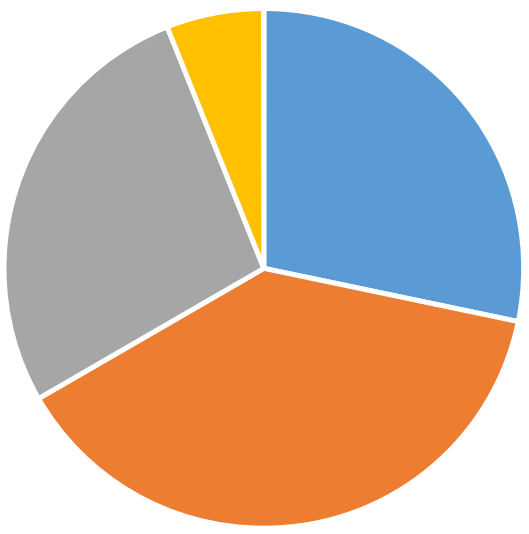

- Full Facility Load - Core Operations

- Life Safety $\quad$ Graceful Shutdown

Figure 5: Backup Generators by Purpose

Table 10 shows the average duration of the backup generator by purpose, and Figure 6 is a boxplot showing the distribution of backup generator duration, by purpose. Due to the wide range in backup generator duration, the $\mathrm{x}$-axis is a logarithmic scale in hours.
Table 17: Backup Generator Purpose and Duration

\begin{tabular}{|l|c|c|}
$\begin{array}{c}\text { Purpose of Backup } \\
\text { Generator }\end{array}$ & $\begin{array}{c}\text { Percentage } \\
(\%) \text { of } \\
\text { Facilities }\end{array}$ & $\begin{array}{c}\text { Average } \\
\text { Duration } \\
\text { (in hours) }\end{array}$ \\
\hline Full Facility Load & 28 & 302 \\
\hline Core Operations & 38 & 394 \\
\hline Life Safety & 27 & 653 \\
\hline Graceful Shutdown & 6 & 725 \\
\hline
\end{tabular}

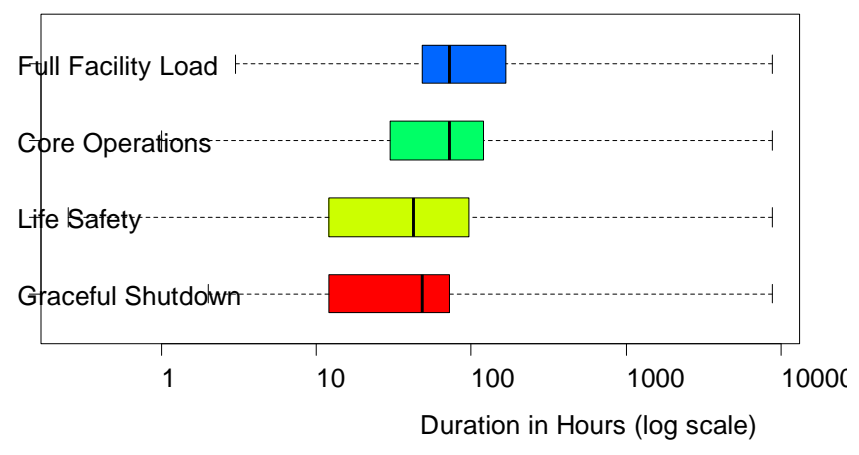

Figure 6: Duration of Backup Generator by Purpose 
Based solely on the average duration, it appears that backup generators designed to provide more power to the facility are able to provide power for a shorter duration. However, according to the boxplots, the median duration is higher for facilities that use backup generators for core functions and full facility load than for those that use them for life safety or graceful shutdown. Those backup generators with long durations skew the averages, regardless of the generator purpose.

Table 11 shows the percentage of facilities with a backup generator, organized by group and purpose.

Table 18: Purpose of Backup Generation by Study Group

\begin{tabular}{|c|c|c|c|c|}
\hline Study Group Name & $\begin{array}{c}\text { Percentage (\%) } \\
\text { of Backup } \\
\text { Generators } \\
\text { Used for a } \\
\text { Graceful } \\
\text { Shutdown }\end{array}$ & $\begin{array}{c}\text { Percentage (\%) } \\
\text { of Backup } \\
\text { Generators Used } \\
\text { for Life Safety }\end{array}$ & $\begin{array}{c}\text { Percentage (\%) } \\
\text { of Backup } \\
\text { Generators } \\
\text { Used for Core } \\
\text { Functions }\end{array}$ & $\begin{array}{c}\text { Percentage (\%) } \\
\text { of Backup } \\
\text { Generators } \\
\text { Used for the } \\
\text { Entire Facility } \\
\text { Load }\end{array}$ \\
\hline Agriculture and Food & 3 & 21 & 41 & 36 \\
\hline Banking and Finance & 0 & 29 & 26 & 45 \\
\hline Commercial Facilities & 2 & 24 & 52 & 22 \\
\hline Communications & 0 & 2 & 26 & 72 \\
\hline Emergency Services & 2 & 8 & 39 & 51 \\
\hline Energy & 4 & 18 & 57 & 21 \\
\hline Government Facilities & 0 & 31 & 41 & 28 \\
\hline Healthcare and Public Health & 6 & 40 & 34 & 19 \\
\hline Manufacturing & 19 & 50 & 23 & 8 \\
\hline Transportation & 3 & 24 & 41 & 32 \\
\hline Water & 10 & 3 & 38 & 50 \\
\hline $\begin{array}{l}\text { Processing, Packaging, and } \\
\text { Production }\end{array}$ & 19 & 33 & 29 & 19 \\
\hline Banking and Credit & 0 & 18 & 40 & 42 \\
\hline Public Assembly & 8 & 61 & 24 & 8 \\
\hline Real Estate Facility & 8 & 65 & 18 & 10 \\
\hline Dam Project & 0 & 0 & 50 & 50 \\
\hline Electricity & 0 & 8 & 72 & 20 \\
\hline Petroleum & 22 & 19 & 42 & 17 \\
\hline Health Supporting Facility & 2 & 11 & 48 & 39 \\
\hline Mass Transit & 0 & 13 & 35 & 52 \\
\hline Road & 0 & 4 & 48 & 48 \\
\hline Wastewater Facility & 0 & 0 & 40 & 60 \\
\hline Water Treatment Facility & 2 & 5 & 34 & 59 \\
\hline Hotel or Motel & 7 & 64 & 24 & 5 \\
\hline Arena & 8 & 71 & 13 & 8 \\
\hline $\begin{array}{l}\text { Community Organization } \\
\text { Facility }\end{array}$ & 9 & 82 & 9 & 0 \\
\hline Stadium & 9 & 80 & 8 & 2 \\
\hline Store Retailer & 7 & 71 & 18 & 4 \\
\hline Hydropower Plant & 3 & 3 & 52 & 41 \\
\hline Water Retention Structure & 4 & 7 & 52 & 37 \\
\hline $\begin{array}{l}\text { Law Enforcement } \\
\text { Administrative } \\
\text { Office/Headquarters }\end{array}$ & 0 & 0 & 68 & 32 \\
\hline Electricity Generation & 20 & 15 & 30 & 35 \\
\hline Electricity Transmission & 0 & 5 & 60 & 35 \\
\hline
\end{tabular}


Table 19: (Cont.)

\begin{tabular}{|c|c|c|c|c|}
\hline Study Group Name & $\begin{array}{c}\text { Percentage (\%) } \\
\text { of Backup } \\
\text { Generators } \\
\text { Used for a } \\
\text { Graceful } \\
\text { Shutdown }\end{array}$ & $\begin{array}{l}\text { Percentage (\%) } \\
\text { of Backup } \\
\text { Generators Used } \\
\text { for Life Safety }\end{array}$ & $\begin{array}{l}\text { Percentage (\%) } \\
\text { of Backup } \\
\text { Generators } \\
\text { Used for Core } \\
\text { Functions }\end{array}$ & $\begin{array}{c}\text { Percentage (\%) } \\
\text { of Backup } \\
\text { Generators } \\
\text { Used for the } \\
\text { Entire Facility } \\
\text { Load }\end{array}$ \\
\hline Higher Education Facility & 6 & 56 & 29 & 10 \\
\hline Pre-K-12 School & 9 & 58 & 25 & 8 \\
\hline Hospital & 0 & 21 & 52 & 27 \\
\hline Port & 5 & 27 & 55 & 14 \\
\hline Wastewater Treatment Plant & 1 & 5 & 36 & 58 \\
\hline Office Building - Stand Alone & 5 & 68 & 21 & 5 \\
\hline Distribution Substation & 0 & 40 & 60 & 0 \\
\hline Transmission Substation & 6 & 19 & 63 & 13 \\
\hline $\begin{array}{l}\text { Office or Office Building } \\
\text { Complex }\end{array}$ & 2 & 53 & 30 & 15 \\
\hline Critical Access Hospital & 0 & 9 & 76 & 15 \\
\hline Road Bridge & 0 & 6 & 65 & 29 \\
\hline Coal-fired Generator & 39 & 23 & 39 & 0 \\
\hline Agency Headquarters & 13 & 39 & 28 & 21 \\
\hline Judicial Chamber or Office & 5 & 47 & 21 & 26 \\
\hline $\begin{array}{l}\text { Private or Private Not-for-Profit } \\
\text { General Medical and Surgical } \\
\text { Hospital }\end{array}$ & 0 & 15 & 66 & 20 \\
\hline $\begin{array}{l}\text { State, Local, or Tribal General } \\
\text { Medical and Surgical Hospital }\end{array}$ & 0 & 21 & 47 & 32 \\
\hline
\end{tabular}

\subsection{Uninterruptible Power System (UPS)}

In addition to, or instead of, the backup generator, facilities may also have a UPS. A UPS is an electrical device that provides emergency power to the facility when it loses its main source of electrical power. The UPS is typically designed to operate for a short amount of time, enough to facilitate safe shutdown of equipment, safe evacuation from a facility, or power to start a backup source of power, such as a generator. However, some facilities confirm using a UPS to provide enough power for core operations, or even the full facility load. A UPS can also be used in conjunction with a backup generator to power different facility functions. For example, the UPS could be used to keep information technology functions operational, while the backup generator is used to keep the security system online.

\subsubsection{UPS Duration}

In general, a UPS provides power for a shorter duration than a backup generator. The median duration for a UPS was 2 hours, compared to 72 hours for a backup generator. In fact, almost half (48 percent) of the facilities with a UPS stated that the duration of supply was an hour or less. 
Of the 1671 facilities that have a UPS, two stated that the UPS could provide power indefinitely (365 days), and another stated that the UPS could provide power for 100 days. The following analysis removes those three facilities from consideration, because they were extreme Table 20: Distribution of UPS Duration outliers; no other facility had a UPS duration of more than 30 days.

Table 12 provides the electrical power duration for all study group facilities with a UPS over five time groups. In Figure 7, a boxplot has been generated to illustrate the distribution of UPS

\begin{tabular}{|l|c|c|}
$\begin{array}{c}\text { Duration of } \\
\text { the UPS }\end{array}$ & $\begin{array}{c}\text { Percentage } \\
\text { (\%) of } \\
\text { Facilities }\end{array}$ & $\begin{array}{c}\text { Average } \\
\text { Duration } \\
\text { (Hours) }\end{array}$ \\
\hline More than 24 Hours & 3 & 466 \\
\hline 12 to 24 Hours & 3 & 23 \\
\hline 6 to 12 Hours & 11 & 9 \\
\hline 1 to 6 Hours & 35 & 3 \\
\hline Less than 1 Hour & 48 & 0.69 \\
\hline
\end{tabular}
duration times within each of those time groupings.

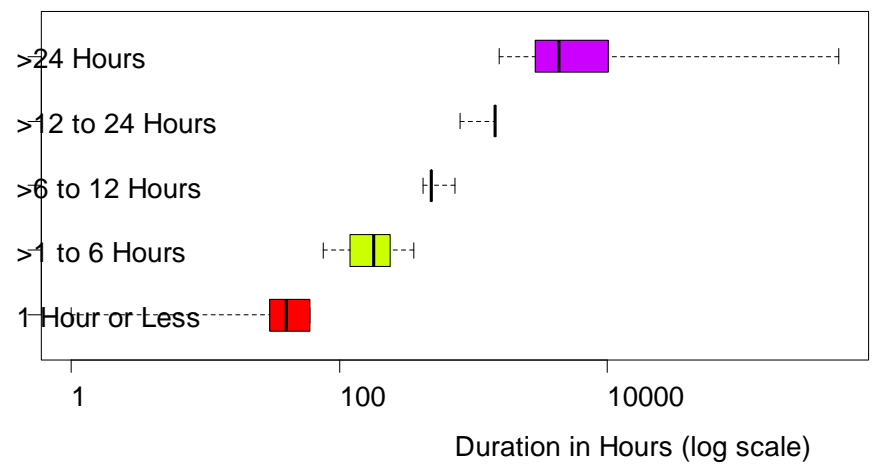

Figure 7: Distribution of UPS Duration

The distribution of facilities with a UPS duration between 6 and 12 hours and those with a UPS duration between 12 and 24 hours is unique. There were 188 facilities with a UPS duration between 6 and 12 hours, 76 percent of which stated they had a duration of 8 hours, and 21 percent of which stated they had a duration of 12 hours. Of the 43 facilities with a UPS duration between 12 and 24 hours, 81 percent stated a duration of 24 hours.

\subsubsection{UPS Purpose}

Similar to the backup generation, the survey tool also collects information on the purpose of the UPS. Table 13 shows the distribution of facilities with a UPS by purpose and average duration for each of the purposes. The boxplot in Figure 8 describes the distribution of UPS duration by purpose. A logarithmic scale was used on the $\mathrm{x}$-axis due to the large differences in UPS duration.

Table 21: Average UPS Duration by Purpose

\begin{tabular}{|l|c|c|}
$\begin{array}{c}\text { Purpose of the } \\
\text { UPS }\end{array}$ & $\begin{array}{c}\text { Percentage } \\
\text { (\%) of } \\
\text { Facilities }\end{array}$ & $\begin{array}{c}\text { Average } \\
\text { Duration } \\
\text { (in hours) }\end{array}$ \\
\hline Full Facility Load & 3 & 10 \\
\hline Core Operations & 31 & 10 \\
\hline Life Safety & 19 & 10 \\
\hline Graceful Shutdown & 47 & 3 \\
\hline
\end{tabular}




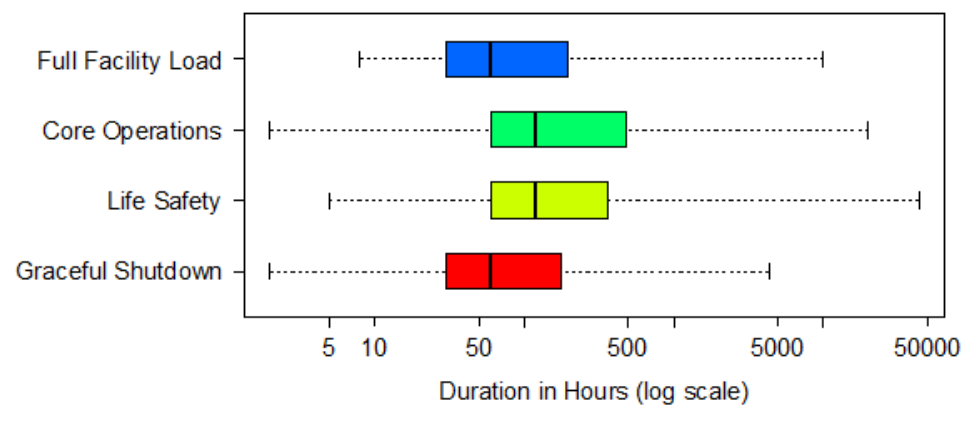

Figure 8: Distribution of UPS Duration by Purpose

The average UPS duration for those used for a graceful shutdown is much shorter than for any of the other three purposes. However, when removing the outliers, we find that the median of UPS duration between the different purposes do not differ greatly.

As shown in Table 13, only 3 percent of facilities have a UPS that can support the full facility load. Table 14 shows the distribution by study group of facilities with a UPS backup by purpose. The study groups with the highest percentage of UPS systems that support the entire facility load are highlighted.

Table 22: UPS by Purpose

\begin{tabular}{|c|c|c|c|c|}
\hline Study Group Name & $\begin{array}{l}\text { Percentage } \\
\text { (\%) Used for a } \\
\text { Graceful } \\
\text { Shutdown }\end{array}$ & $\begin{array}{l}\text { Percentage } \\
\text { (\%) Used for } \\
\text { Life Safety }\end{array}$ & $\begin{array}{l}\text { Percentage (\%) } \\
\text { Used for Core } \\
\text { Functions }\end{array}$ & $\begin{array}{l}\text { Percentage } \\
\text { (\%) Used for } \\
\text { Entire } \\
\text { Facility Load }\end{array}$ \\
\hline Agriculture and Food & 68 & 4 & 24 & 4 \\
\hline Banking and Finance & 53 & 7 & 30 & 10 \\
\hline Commercial Facilities & 48 & 20 & 33 & 0 \\
\hline Communications & 25 & 8 & 57 & 11 \\
\hline Emergency Services & 32 & 3 & 51 & 14 \\
\hline Energy & 47 & 11 & 42 & 0 \\
\hline Government Facilities & 27 & 23 & 50 & 0 \\
\hline Healthcare and Public Health & 65 & 24 & 8 & 3 \\
\hline Manufacturing & 65 & 22 & 13 & 0 \\
\hline Transportation & 57 & 9 & 35 & 0 \\
\hline Water & 37 & 9 & 51 & 4 \\
\hline Processing, Packaging, and Production & 79 & 7 & 14 & 0 \\
\hline Banking and Credit & 33 & 5 & 59 & 3 \\
\hline Public Assembly & 49 & 35 & 16 & 0 \\
\hline Real Estate Facility & 41 & 36 & 23 & 0 \\
\hline Dam Project & 21 & 7 & 71 & 0 \\
\hline Electricity & 22 & 0 & 70 & 9 \\
\hline Petroleum & 53 & 6 & 41 & 0 \\
\hline Health Supporting Facility & 34 & 16 & 47 & 3 \\
\hline Mass Transit & 53 & 20 & 20 & 7 \\
\hline Road & 52 & 8 & 24 & 16 \\
\hline
\end{tabular}


Table 23: (Cont.)

\begin{tabular}{|l|c|c|c|c|}
\hline \multicolumn{1}{|c|}{ Study Group Name } & $\begin{array}{c}\text { Percentage } \\
\text { (\%) Used for a } \\
\text { Graceful } \\
\text { Shutdown }\end{array}$ & $\begin{array}{c}\text { Percentage } \\
\text { (\%) Used for } \\
\text { Life Safety }\end{array}$ & $\begin{array}{c}\text { Percentage (\%) } \\
\text { Used for Core } \\
\text { Functions }\end{array}$ & $\begin{array}{c}\text { Percentage } \\
\text { (\%) Used for } \\
\text { Entire }\end{array}$ \\
Facility Load
\end{tabular}

\subsection{Facilities with UPS and Backup Generation}

In addition to the purpose of the UPS, the survey tool also collects information on the use of the UPS. Often a facility will have both a backup generator and a UPS to protect against external electric power loss. Approximately 52 percent of facilities that depend on external power have both a backup generator and a UPS. Approximately 21 percent of the facilities only have a backup generator, and only 2 percent of the facilities have only a UPS.

Facilities that have both a backup generator and a UPS do not always use them both for the same purpose. In fact, approximately 30 percent of the facilities with both stated that they used both for the same purpose. 
Table 15 shows the percentage of facilities with a UPS and a backup generator that use each for a particular purpose. Almost half of these facilities (47 percent) use the UPS for a graceful shutdown, while the backup generator fulfills another purpose. Very rarely is the UPS used to support the entire facility load (3 percent). This makes sense, because most UPSs can only provide power for a very short duration in relation to a backup generator.

Table 24: UPS and Backup Generator Purpose for Facilities with Both

\begin{tabular}{|l|c|c|c|c|c|}
\hline & \multicolumn{5}{|c|}{ Backup Generator Purpose } \\
\cline { 2 - 7 } \multicolumn{1}{c|}{} & $\begin{array}{c}\text { Core } \\
\text { UPS Purpose }\end{array}$ & $\begin{array}{c}\text { Entire Facility } \\
\text { Load (\%) }\end{array}$ & $\begin{array}{c}\text { Graceful } \\
\text { Shutdown (\%) }\end{array}$ & $\begin{array}{c}\text { Life Safety } \\
(\%)\end{array}$ & Totals (\%) \\
\hline Core Operations & 16 & 12 & 0 & 3 & 31 \\
\hline Entire Load & 0 & 2 & 1 & 16 & 3 \\
\hline Graceful Shutdown & 16 & 11 & 4 & 8 & 19 \\
\hline Life Safety & 6 & 3 & 1 & 27 & 47 \\
\hline Totals & 38 & 28 & 6 & & \\
\hline
\end{tabular}


Onsite and Electric Power Backup Capabilities at Critical Infrastructure Facilities in the United States

This page intentionally left blank. 


\section{Facility Analysis by Census Region}

In order to investigate differences in backup capabilities across the nation, analysis similar to that described above was conducted for study groups across census regions. These results could help inform regional differences that might be caused by a number of factors, including climate, regulations, and type of infrastructure. Table 16 partitions the facilities within the 49 study groups across the four census regions based on facility location.

Table 25: Number of Facilities by Groups for the Four Census Regions ${ }^{a}$

\begin{tabular}{|c|c|c|c|c|}
\hline Study Group Name & Midwest & Northeast & South & West \\
\hline Agriculture and Food & 9 & 12 & 20 & 20 \\
\hline Banking and Finance & 7 & 14 & 9 & 1 \\
\hline Commercial Facilities & 8 & 10 & 16 & 15 \\
\hline Communications & 3 & 2 & 26 & 23 \\
\hline Emergency Services & 9 & 15 & 19 & 9 \\
\hline Energy & 12 & 9 & 14 & 4 \\
\hline Government Facilities & 9 & 9 & 20 & 9 \\
\hline Healthcare and Public Health & 26 & 13 & 17 & 2 \\
\hline Manufacturing & 12 & 6 & 14 & 3 \\
\hline Transportation & 6 & 9 & 20 & 12 \\
\hline Water & 13 & 17 & 38 & 31 \\
\hline Processing, Packaging, and Production & 10 & 12 & 5 & 16 \\
\hline Banking and Credit & 16 & 5 & 20 & 11 \\
\hline Public Assembly & 27 & 22 & 53 & 20 \\
\hline Real Estate Facility & 19 & 10 & 11 & 6 \\
\hline Dam Project & 1 & 2 & 21 & 10 \\
\hline Electricity & 9 & 9 & 8 & 7 \\
\hline Petroleum & 4 & 10 & 35 & 10 \\
\hline Health Supporting Facility & 9 & 19 & 14 & 8 \\
\hline Mass Transit & 15 & 4 & 11 & 2 \\
\hline Road & 6 & 3 & 15 & 7 \\
\hline Wastewater Facility & 0 & 6 & 13 & 17 \\
\hline Water Treatment Facility & 43 & 47 & 50 & 27 \\
\hline Hotel or Motel & 15 & 5 & 28 & 12 \\
\hline Arena & 19 & 10 & 32 & 21 \\
\hline Community Organization Facility & 25 & 8 & 10 & 4 \\
\hline Stadium & 23 & 9 & 51 & 25 \\
\hline Store Retailer & 3 & 11 & 8 & 11 \\
\hline Hydropower Plant & 2 & 2 & 8 & 26 \\
\hline Water Retention Structure & 3 & 3 & 20 & 11 \\
\hline $\begin{array}{l}\text { Law Enforcement Administrative } \\
\text { Office/Headquarters }\end{array}$ & 10 & 1 & 4 & 17 \\
\hline Electricity Generation & 6 & 10 & 10 & 14 \\
\hline Electricity Transmission & 7 & 6 & 6 & 13 \\
\hline Higher Education Facility & 59 & 32 & 36 & 5 \\
\hline Pre-K-12 School & 84 & 58 & 105 & 71 \\
\hline Hospital & 10 & 16 & 18 & 9 \\
\hline Port & 0 & 6 & 27 & 4 \\
\hline Wastewater Treatment Plant & 9 & 23 & 42 & 26 \\
\hline Office Building - Stand Alone & 14 & 8 & 10 & 11 \\
\hline
\end{tabular}


Table 26: (Cont.)

\begin{tabular}{|c|c|c|c|c|}
\hline Study Group Name & Midwest & Northeast & South & West \\
\hline Distribution Substation & 2 & 12 & 18 & 12 \\
\hline Transmission Substation & 26 & 34 & 11 & 43 \\
\hline Office or Office Building Complex & 17 & 16 & 20 & 13 \\
\hline Critical Access Hospital & 26 & 5 & 2 & 0 \\
\hline Road Bridge & 1 & 3 & 37 & 32 \\
\hline Coal-fired Generator & 24 & 0 & 4 & 3 \\
\hline Agency Headquarters & 17 & 4 & 18 & 12 \\
\hline Judicial Chamber or Office & 11 & 5 & 18 & 16 \\
\hline $\begin{array}{l}\text { Private or Private Not-for-Profit General } \\
\text { Medical and Surgical Hospital }\end{array}$ & 35 & 55 & 28 & 13 \\
\hline $\begin{array}{l}\text { State, Local, or Tribal General Medical } \\
\text { and Surgical Hospital }\end{array}$ & 11 & 2 & 15 & 6 \\
\hline
\end{tabular}

When considering the study groups by census region, many contain fewer than 30 facilities. In order to maintain facility groupings of the desired size of 30 or more, an additional aggregation was performed within census regions, similar to the aggregation methodology used to create the 49 original study groups. The results of this census region level aggregation are shown in Table 17. Facility groups that did not have at least 30 in any census region and could not be aggregated even to the sector level are removed from further analysis.

Table 27: Number of Facilities by Taxonomy Level for the Four Census Regions

\begin{tabular}{|c|c|c|c|c|c|c|c|c|}
\hline Sector & Subsector & Segment & $\begin{array}{c}\text { Sub- } \\
\text { segment }\end{array}$ & Asset & Midwest & $\begin{array}{l}\text { North- } \\
\text { east }\end{array}$ & $\begin{array}{c}\text { Sout } \\
h\end{array}$ & West \\
\hline \multicolumn{5}{|c|}{ Agriculture and Food } & 19 & 24 & 25 & 36 \\
\hline \multicolumn{5}{|c|}{ Banking and Finance ${ }^{a}$} & 23 & 19 & 29 & 12 \\
\hline \multicolumn{5}{|c|}{ Chemical and Hazardous Materials Industry ${ }^{a}$} & 1 & 4 & 7 & 4 \\
\hline \multicolumn{5}{|c|}{ Commercial Facilities $^{a}$} & 11 & 18 & 22 & 20 \\
\hline & \multicolumn{4}{|c|}{ Lodging Facility } & 15 & 8 & 30 & 18 \\
\hline & \multicolumn{4}{|c|}{ Public Assembly } & 52 & 30 & 63 & 24 \\
\hline & & \multicolumn{3}{|l|}{ Arena } & 19 & 10 & 32 & 21 \\
\hline & & \multicolumn{3}{|l|}{ Stadium } & 23 & 9 & 51 & 25 \\
\hline & \multicolumn{4}{|c|}{ Real Estate Facility } & 33 & 18 & 21 & 17 \\
\hline \multicolumn{5}{|c|}{ Communications $^{\mathrm{a}}$} & 3 & 2 & 26 & 23 \\
\hline \multicolumn{5}{|l|}{ Dams $^{a}$} & 0 & 1 & 10 & 0 \\
\hline & \multicolumn{4}{|l|}{ Dam Project } & 6 & 7 & 49 & 47 \\
\hline \multicolumn{5}{|c|}{ Defense Industrial Base ${ }^{a}$} & 8 & 9 & 5 & 4 \\
\hline \multicolumn{5}{|c|}{ Emergency Services $^{\mathrm{a}}$} & 19 & 16 & 23 & 26 \\
\hline \multicolumn{5}{|c|}{ Energy $^{\mathrm{a}}$} & 12 & 9 & 14 & 4 \\
\hline & \multicolumn{4}{|l|}{ Electricity } & 18 & 27 & 32 & 32 \\
\hline & & \multicolumn{3}{|c|}{ Electricity Generation } & 30 & 10 & 14 & 17 \\
\hline & & & Transmissic & tation & 26 & 34 & 11 & 43 \\
\hline & \multicolumn{4}{|l|}{ Petroleum } & 4 & 10 & 35 & 10 \\
\hline
\end{tabular}


Table 28: (Cont.)

\begin{tabular}{|c|c|c|c|c|c|c|c|c|}
\hline Sector & Subsector & Segment & $\begin{array}{l}\text { Sub- } \\
\text { segment }\end{array}$ & Asset & Midwest & $\begin{array}{l}\text { North- } \\
\text { east }\end{array}$ & $\begin{array}{c}\text { Sout } \\
h\end{array}$ & West \\
\hline \multicolumn{5}{|c|}{ Government Facilities $^{a}$} & 9 & 9 & 20 & 9 \\
\hline & & \multicolumn{3}{|c|}{ Higher Education Facility } & 59 & 32 & 36 & 5 \\
\hline & & \multicolumn{3}{|c|}{ Pre K-12 School } & 84 & 58 & 105 & 71 \\
\hline & & & \multicolumn{2}{|c|}{$\begin{array}{l}\text { Office or Office Building } \\
\text { Complex }\end{array}$} & 45 & 25 & 56 & 41 \\
\hline \multicolumn{5}{|c|}{ Health Care and Public Health } & 35 & 32 & 31 & 10 \\
\hline & & \multicolumn{3}{|l|}{ Hospital } & 47 & 23 & 35 & 15 \\
\hline & & & & $\begin{array}{l}\text { Private or Not- } \\
\text { For-Profit } \\
\text { General Medical } \\
\text { and Surgical } \\
\text { Hospital }\end{array}$ & 35 & 55 & 28 & 13 \\
\hline \multicolumn{5}{|c|}{ Information Technology $^{a}$} & 3 & 4 & 7 & 1 \\
\hline \multicolumn{5}{|c|}{ Manufacturing $^{\mathrm{a}}$} & 12 & 6 & 14 & 3 \\
\hline \multicolumn{5}{|c|}{ National Monuments and Icons ${ }^{a}$} & 2 & 1 & 1 & 0 \\
\hline \multicolumn{5}{|c|}{ Nuclear Reactors, Materials, and Waste ${ }^{a}$} & 1 & 0 & 4 & 0 \\
\hline \multicolumn{5}{|c|}{ Postal and Shipping ${ }^{a}$} & 0 & 0 & 0 & 1 \\
\hline \multicolumn{5}{|c|}{ Transportation } & 27 & 15 & 35 & 21 \\
\hline & \multicolumn{4}{|l|}{ Maritime } & 0 & 7 & 38 & 4 \\
\hline & & & Road Bridge & & 1 & 3 & 37 & 32 \\
\hline \multicolumn{5}{|l|}{ Water } & 13 & 23 & 51 & 48 \\
\hline & & \multicolumn{3}{|c|}{ Wastewater Treatment Plant } & 9 & 23 & 42 & 26 \\
\hline & \multicolumn{4}{|c|}{ Water Treatment Facility } & 43 & 47 & 50 & 27 \\
\hline
\end{tabular}

${ }^{a}$ Facility groups that did not have at least 30 in any census region and could not be aggregated even to the sector level, which were removed from further analysis.

Table 18 contains a consolidated list of census groupings organized by taxonomy aggregation level. The groups with fewer than 30 facilities (as identified in Table 17) were removed. The new aggregated groups are referred to as "census groups" in order to distinguish the 23 census region study groups from the original set of 49 facility study groups (see Section 2).

For the remainder of this report, statistics will be shown for both study groups - the 49 facility study groups as well as the 23 census region study groups. The original facility grouping is used for continuity with Section 4 of the report, even though the sample sizes often are too small to state confidence in the descriptive statistics. The original set of groups (49) are referred to as "Group A." The second set of groups (23), aggregating by the taxonomy within each census region, is referred to as "Group B."

As with the analysis presented in Section 4, the following sections will investigate internal and alternative backup generation capabilities for both Groups A and B across the four census regions. 
Table 29: Census Region Study Groups

\begin{tabular}{|c|c|c|c|c|c|}
\hline Census Group Name & $\begin{array}{l}\text { Taxonomy } \\
\text { Level }\end{array}$ & Midwest & Northeast & South & West \\
\hline Agriculture and Food Census Group & Sector & 19 & 24 & 25 & 36 \\
\hline Healthcare and Public Health Census Group & Sector & 35 & 32 & 31 & 10 \\
\hline Transportation Census Group & Sector & 27 & 15 & 35 & 21 \\
\hline Water Census Group & Sector & 13 & 23 & 51 & 48 \\
\hline Lodging Facility Census Group & Subsector & 15 & 8 & 30 & 18 \\
\hline Public Assembly Census Group & Subsector & 52 & 30 & 63 & 24 \\
\hline Real Estate Facility Census Group & Subsector & 33 & 18 & 21 & 17 \\
\hline Dam Project Census Group & Subsector & 6 & 7 & 49 & 47 \\
\hline Electricity Census Group & Subsector & 18 & 27 & 32 & 32 \\
\hline Petroleum Census Group & Subsector & 4 & 10 & 35 & 10 \\
\hline Maritime Census Group & Subsector & 0 & 7 & 38 & 4 \\
\hline Water Treatment Facility Census Group & Subsector & 43 & 47 & 50 & 27 \\
\hline Arena Census Group & Segment & 19 & 10 & 32 & 21 \\
\hline Stadium Census Group & Segment & 23 & 9 & 51 & 25 \\
\hline Electricity Generation Census Group & Segment & 30 & 10 & 14 & 17 \\
\hline Higher Education Facility Census Group & Segment & 59 & 32 & 36 & 5 \\
\hline Pre-K-12 School Census Group & Segment & 84 & 58 & 105 & 71 \\
\hline Hospital Census Group & Segment & 47 & 23 & 35 & 15 \\
\hline Wastewater Treatment Plant Census Group & Segment & 9 & 23 & 42 & 26 \\
\hline Transmission Substation Census Group & Subsegment & 26 & 34 & 11 & 43 \\
\hline $\begin{array}{l}\text { Office or Office Building Complex Census } \\
\text { Group }\end{array}$ & Subsegment & 45 & 25 & 56 & 41 \\
\hline Road Bridge Census Group & Subsegment & 1 & 3 & 37 & 32 \\
\hline $\begin{array}{l}\text { Private or Private Not-for-Profit General Medical } \\
\text { and Surgical Hospital Census Group }\end{array}$ & Asset & 35 & 55 & 28 & 13 \\
\hline \multicolumn{2}{|l|}{ Total } & 643 & 530 & 907 & 603 \\
\hline
\end{tabular}

\subsection{External Electric Power Dependence by Census Region}

Electric dependence of critical infrastructure is high across all census regions. Table 19 shows the percentage of the facilities in each census region that are dependent upon an external source for electric power.

Table 30: External Electrical Power Dependence by Census Region

\begin{tabular}{l|c}
$\begin{array}{l}\text { Census } \\
\text { Region }\end{array}$ & $\begin{array}{c}\text { Percentage (\%) of Facilities } \\
\text { Dependent on External Electrical } \\
\text { Power }\end{array}$ \\
\hline Midwest & 93 \\
\hline Northeast & 95 \\
\hline South & 92 \\
\hline West & 82 \\
\hline
\end{tabular}

Tables 20 and 21 present the percentage of facilities that are dependent upon external electrical power from Group A and Group B, respectively. Percentages that have been calculated from a sample size of 30 or more are highlighted in both tables. 
Table 31: Group A Facilities Dependent upon External Electrical Power, by Census Regiona

\begin{tabular}{|c|c|c|c|c|}
\hline Group Name & Midwest (\%) & Northeast (\%) & South $(\%)$ & West (\%) \\
\hline Agriculture and Food & 100 & 100 & 100 & 100 \\
\hline Banking and Finance & 100 & 100 & 100 & 100 \\
\hline Commercial Facilities & 100 & 100 & 100 & 100 \\
\hline Communications & 100 & 100 & 100 & 100 \\
\hline Emergency Services & 100 & 100 & 100 & 100 \\
\hline Energy & 100 & 100 & 100 & 100 \\
\hline Government Facilities & 100 & 100 & 100 & 100 \\
\hline Healthcare and Public Health & 100 & 100 & 100 & 100 \\
\hline Manufacturing & 100 & 100 & 100 & 100 \\
\hline Transportation & 67 & 78 & 95 & 83 \\
\hline Water & 100 & 100 & 92 & 94 \\
\hline Processing, Packaging, and Production & 100 & 100 & 100 & 100 \\
\hline Banking and Credit & 100 & 100 & 100 & 100 \\
\hline Public Assembly & 100 & 96 & 100 & 100 \\
\hline Real Estate Facility & 100 & 100 & 100 & 100 \\
\hline Dam Project & 100 & 50 & 86 & 70 \\
\hline Electricity & 78 & 67 & 88 & 86 \\
\hline Petroleum & 100 & 100 & 100 & 90 \\
\hline Health Supporting Facility & 100 & 100 & 100 & 100 \\
\hline Mass Transit & 100 & 100 & 100 & 100 \\
\hline Road & 83 & 100 & 100 & 86 \\
\hline Wastewater Facility & ----- & 100 & 100 & 94 \\
\hline Water Treatment Facility & 100 & 100 & 100 & 100 \\
\hline Hotel or Motel & 100 & 100 & 100 & 100 \\
\hline Arena & 100 & 100 & 100 & 100 \\
\hline Community Organization Facility & 100 & 100 & 100 & 100 \\
\hline Stadium & 100 & 100 & 100 & 96 \\
\hline Store Retailer & 100 & 100 & 100 & 100 \\
\hline Hydropower Plant & 100 & 50 & 88 & 77 \\
\hline Water Retention Structure & 100 & 67 & 95 & 64 \\
\hline $\begin{array}{l}\text { Law Enforcement Administrative } \\
\text { Office/Headquarters }\end{array}$ & 100 & 100 & 100 & 100 \\
\hline Electricity Generation & 50 & 80 & 40 & 72 \\
\hline Electricity Transmission & 71 & 100 & 67 & 54 \\
\hline Higher Education Facility & 100 & 100 & 100 & 100 \\
\hline Pre-K-12 School & 100 & 100 & 100 & 100 \\
\hline Hospital & 100 & 100 & 100 & 100 \\
\hline Port & ----- & 83 & 100 & 100 \\
\hline Wastewater Treatment Plant & 100 & 100 & 100 & 93 \\
\hline Office Building - Stand Alone & 100 & 100 & 100 & 100 \\
\hline Distribution Substation & 0 & 58 & 6 & 25 \\
\hline Transmission Substation & 8 & 74 & 18 & 16 \\
\hline Office or Office Building Complex & 100 & 100 & 100 & 100 \\
\hline Critical Access Hospital & 100 & 100 & 100 & ----- \\
\hline Road Bridge & 100 & 67 & 30 & 16 \\
\hline Coal-fired Generator & 63 & ----- & 75 & 100 \\
\hline Agency Headquarters & 100 & 100 & 100 & 100 \\
\hline Judicial Chamber or Office & 100 & 100 & 100 & 100 \\
\hline $\begin{array}{l}\text { Private or Private Not-for-Profit General } \\
\text { Medical and Surgical Hospital }\end{array}$ & 100 & 100 & 100 & 100 \\
\hline $\begin{array}{l}\text { State, Local, or Tribal General Medical } \\
\text { and Surgical Hospital }\end{array}$ & 100 & 100 & 100 & 100 \\
\hline
\end{tabular}

${ }^{\text {a }}$ Percentages that have been calculated from a sample size of 30 or more are highlighted 
Table 32: Group B Facilities That Depend upon External Electrical Power, by Census Regiona

\begin{tabular}{|c|c|c|c|c|}
\hline Census Group Name & Midwest (\%) & Northeast (\%) & South (\%) & West (\%) \\
\hline Agriculture and Food Census Group & 100 & 100 & 100 & 100 \\
\hline Healthcare and Public Health Census Group & 100 & 100 & 100 & 100 \\
\hline Transportation Census Group & 89 & 93 & 97 & 86 \\
\hline Water Census Group & 100 & 100 & 94 & 94 \\
\hline Lodging Facility Census Group & 100 & 100 & 100 & 100 \\
\hline Public Assembly Census Group & 100 & 97 & 100 & 100 \\
\hline Real Estate Facility Census Group & 100 & 100 & 100 & 100 \\
\hline Dam Project Census Group & 100 & 57 & 90 & 72 \\
\hline Electricity Census Group & 67 & 70 & 38 & 50 \\
\hline Petroleum Census Group & 100 & 100 & 100 & 90 \\
\hline Maritime Census Group & ----- & 71 & 100 & 100 \\
\hline Water Treatment Facility Census Group & 100 & 100 & 100 & 100 \\
\hline Arena Census Group & 100 & 100 & 100 & 100 \\
\hline Stadium Census Group & 100 & 100 & 100 & 96 \\
\hline Electricity Generation Census Group & 60 & 80 & 50 & 76 \\
\hline Higher Education Facility Census Group & 100 & 100 & 100 & 100 \\
\hline Pre-K-12 School Census Group & 100 & 100 & 100 & 100 \\
\hline Hospital Census Group & 100 & 100 & 100 & 100 \\
\hline Wastewater Treatment Plant Census Group & 100 & 100 & 100 & 92 \\
\hline Transmission Substation Census Group & 8 & 74 & 18 & 16 \\
\hline $\begin{array}{l}\text { Office or Office Building Complex Census } \\
\text { Group }\end{array}$ & 100 & 100 & 100 & 100 \\
\hline Road Bridge Census Group & 100 & 67 & 30 & 16 \\
\hline $\begin{array}{l}\text { Private or Private Not-for-Profit General } \\
\text { Medical and Surgical Hospital Census Group }\end{array}$ & 100 & 100 & 100 & 100 \\
\hline
\end{tabular}

${ }^{\text {a }}$ Percentages that have been calculated from a sample size of 30 or more are highlighted

\subsection{External Electric Power Mitigation Measures by Census Region}

As previously discussed, additional information was collected on several electric dependence mitigation measures via the survey. The mitigation measures considered are an internal source of power and alternate or backups, which includes alternate sources (i.e., solar generation); backup generators; and UPS. Table 22 shows the percentage of facilities within each census region that have an internal electric power source, those that have an alternate or backup, and those that have both. The last column contains the percentage of facilities that do not have either an onsite electrical generating capability or an alternate or backup within each census region.

Table 33: Electric Dependence Mitigation Measures by Region

\begin{tabular}{|c|c|c|c|c|}
\hline $\begin{array}{l}\text { Census } \\
\text { Region }\end{array}$ & $\begin{array}{c}\text { Percentage (\%) } \\
\text { with an Internal } \\
\text { Electric Power } \\
\text { Source }\end{array}$ & $\begin{array}{c}\text { Percentage (\%) } \\
\text { with an } \\
\text { Alternate or } \\
\text { Backup }\end{array}$ & $\begin{array}{l}\text { Percentage (\%) with } \\
\text { Internal Electric } \\
\text { Power and an } \\
\text { Alternate or Backup }\end{array}$ & $\begin{array}{l}\text { Percentage (\%) } \\
\text { with Neither } \\
\text { Mitigation } \\
\text { Measure }\end{array}$ \\
\hline Midwest & 6 & 73 & 5 & 27 \\
\hline Northeast & 7 & 85 & 7 & 15 \\
\hline South & 4 & 83 & 3 & 17 \\
\hline West & 8 & 77 & 7 & 22 \\
\hline
\end{tabular}




\subsubsection{Internal Generation Capability by Census Region}

As in Section 4.1, internal generation capabilities are scarce across the census regions. Tables 23 and 24 show the percentage of facilities that depend on external electrical power that have onsite electrical power generation capability by census region for Group A and Group B, respectively. Groups with 30 or more sites are highlighted.

Table 34: Internal Generation Capability by Census Region (Group A)a

\begin{tabular}{|c|c|c|c|c|}
\hline Group Name & Midwest (\%) & Northeast (\%) & South (\%) & West (\%) \\
\hline Agriculture and Food & 0 & 0 & 0 & 5 \\
\hline Banking and Finance & 0 & 0 & 0 & 0 \\
\hline Commercial Facilities & 0 & 10 & 13 & 0 \\
\hline Communications & 0 & 0 & 0 & 4 \\
\hline Emergency Services & 0 & 0 & 0 & 0 \\
\hline Energy & 0 & 22 & 0 & 0 \\
\hline Government Facilities & 11 & 0 & 0 & 0 \\
\hline Healthcare and Public Health & 0 & 0 & 6 & 0 \\
\hline Manufacturing & 17 & 0 & 7 & 0 \\
\hline Transportation & 0 & 0 & 0 & 10 \\
\hline Water & 0 & 6 & 3 & 0 \\
\hline Processing, Packaging, and Production & 40 & 0 & 20 & 0 \\
\hline Banking and Credit & 0 & 0 & 5 & 0 \\
\hline Public Assembly & 4 & 10 & 0 & 10 \\
\hline Real Estate Facility & 5 & 10 & 0 & 0 \\
\hline Dam Project & 0 & 0 & 0 & 14 \\
\hline Electricity & 14 & 0 & 0 & 17 \\
\hline Petroleum & 0 & 0 & 6 & 0 \\
\hline Health Supporting Facility & 0 & 16 & 14 & 0 \\
\hline Mass Transit & 0 & 0 & 0 & 0 \\
\hline Road & 0 & 0 & 0 & 0 \\
\hline Wastewater Facility & ---- & 17 & 0 & 0 \\
\hline Water Treatment Facility & 2 & 9 & 2 & 4 \\
\hline Hotel or Motel & 0 & 0 & 4 & 0 \\
\hline Arena & 0 & 10 & 6 & 5 \\
\hline Community Organization Facility & 0 & 0 & 0 & 0 \\
\hline Stadium & 4 & 11 & 8 & 4 \\
\hline Store Retailer & 0 & 9 & 0 & 0 \\
\hline Hydropower Plant & 0 & 100 & 14 & 85 \\
\hline Water Retention Structure & 0 & 0 & 0 & 14 \\
\hline $\begin{array}{l}\text { Law Enforcement Administrative } \\
\text { Office/Headquarters }\end{array}$ & 0 & 0 & 0 & 0 \\
\hline Electricity Generation & 33 & 50 & 50 & 60 \\
\hline Electricity Transmission & 0 & 0 & 0 & 14 \\
\hline Higher Education Facility & 0 & 22 & 8 & 0 \\
\hline Pre-K-12 School & 0 & 2 & 0 & 3 \\
\hline Hospital & 10 & 0 & 0 & 0 \\
\hline Port & ----- & 20 & 0 & 0 \\
\hline Wastewater Treatment Plant & 11 & 17 & 10 & 17 \\
\hline Office Building - Stand Alone & 0 & 0 & 0 & 9 \\
\hline Distribution Substation & ---- & 0 & 100 & 0 \\
\hline Transmission Substation & 0 & 0 & 0 & 0 \\
\hline Office or Office Building Complex & 29 & 0 & 0 & 0 \\
\hline Critical Access Hospital & 0 & 0 & 0 & ----- \\
\hline Road Bridge & 0 & 0 & 0 & 0 \\
\hline Coal-fired Generator & 87 & ----- & 100 & 100 \\
\hline Agency Headquarters & 29 & 0 & 0 & 8 \\
\hline
\end{tabular}


Table 35: (Cont.)

\begin{tabular}{|c|c|c|c|c|}
\hline Group Name & Midwest (\%) & Northeast (\%) & South (\%) & West (\%) \\
\hline Judicial Chamber or Office & 0 & 0 & 0 & 0 \\
\hline $\begin{array}{l}\text { Private or Private Not-for-Profit General } \\
\text { Medical and Surgical Hospital }\end{array}$ & 6 & 9 & 4 & 15 \\
\hline $\begin{array}{l}\text { State, Local, or Tribal General Medical } \\
\text { and Surgical Hospital }\end{array}$ & 0 & 50 & 7 & 0 \\
\hline
\end{tabular}

${ }^{a}$ Groups with 30 or more sites are highlighted.

Table 36: Internal Generation Capability by Census Region (Group B) ${ }^{\mathrm{a}}$

\begin{tabular}{|c|c|c|c|c|}
\hline Census Group Name & Midwest (\%) & Northeast (\%) & South (\%) & West (\%) \\
\hline Agriculture and Food Census Group & 21 & 0 & 4 & 3 \\
\hline Healthcare and Public Health Census Group & 0 & 9 & 10 & 0 \\
\hline Transportation Census Group & 0 & 0 & 0 & 6 \\
\hline Water Census Group & 0 & 9 & 2 & 0 \\
\hline Lodging Facility Census Group & 0 & 0 & 3 & 0 \\
\hline Public Assembly Census Group & 2 & 7 & 0 & 8 \\
\hline Real Estate Facility Census Group & 3 & 6 & 0 & 6 \\
\hline Dam Project Census Group & 0 & 25 & 2 & 56 \\
\hline Electricity Census Group & 8 & 0 & 8 & 13 \\
\hline Petroleum Census Group & 0 & 0 & 6 & 0 \\
\hline Maritime Census Group & ---- & 20 & 0 & 0 \\
\hline Water Treatment Facility Census Group & 2 & 9 & 2 & 4 \\
\hline Arena Census Group & 0 & 10 & 6 & 5 \\
\hline Stadium Census Group & 4 & 11 & 8 & 4 \\
\hline Electricity Generation Census Group & 78 & 50 & 71 & 69 \\
\hline Higher Education Facility Census Group & 0 & 22 & 8 & 0 \\
\hline Pre-K-12 School Census Group & 0 & 2 & 0 & 3 \\
\hline Hospital Census Group & 2 & 4 & 3 & 0 \\
\hline Wastewater Treatment Plant Census Group & 11 & 17 & 10 & 17 \\
\hline Transmission Substation Census Group & 0 & 0 & 0 & 0 \\
\hline Office or Office Building Complex Census Group & 22 & 0 & 0 & 2 \\
\hline Road Bridge Census Group & 0 & 0 & 0 & 0 \\
\hline $\begin{array}{l}\text { Private or Private Not-for-Profit General Medical } \\
\text { and Surgical Hospital Census Group }\end{array}$ & 6 & 9 & 4 & 15 \\
\hline
\end{tabular}

${ }^{\text {a }}$ Groups with 30 or more sites are highlighted.

Table 25 illustrates the internal generation capacity of all facilities (see Table 22, Column 1), by census region. The second column provides the percent of those facilities that cannot sustain full facility load by census region. Figure 9 depicts the distribution of the percentage of full facility load that the facilities without full capability can sustain.
Table 37: Internal Generation Capacity Less than Full Facility Load by Census Region

\begin{tabular}{|l|c|}
$\begin{array}{l}\text { Census } \\
\text { Region }\end{array}$ & $\begin{array}{c}\text { Percentage (\%) of } \\
\text { Facilities w/o Full } \\
\text { Load Capacity }\end{array}$ \\
\hline Midwest & 21 \\
\hline Northeast & 46 \\
\hline South & 43 \\
\hline West & 24 \\
\hline
\end{tabular}




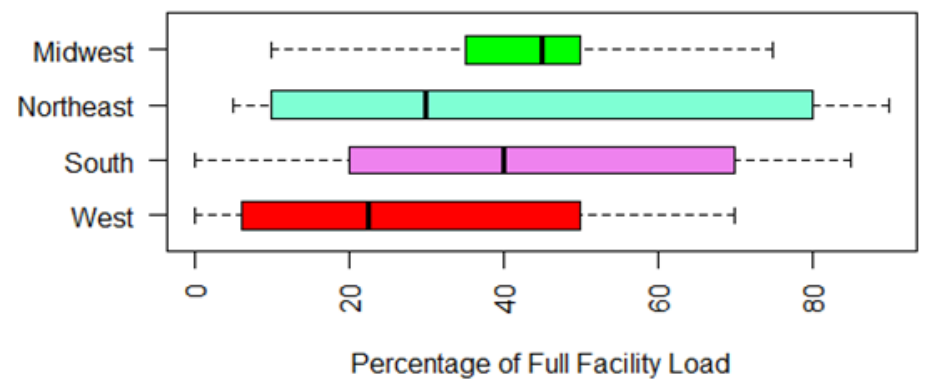

Figure 9: Percentage of Full Facility Load that the Facilities without Full Capacity can Sustain

Although small numbers prevent meaningful tests of statistical significance, Table 25 allows some general observations. Based on the second column, it is apparent that a larger percentage of facilities in the Midwest and West can sustain a full facility load than in the Northeast and South. However, based on the boxplot, facilities in the West that could not sustain a full facility load seem to support a median percentage much lower than the other three regions.

\subsubsection{Alternate or Backup by Census Region}

Tables 26 and 27 show the percentage of the facilities that have an alternate or backup source of power for Group A and Group B, respectively. Recall from Section 4.2 that an alternate source of power can be anything from steam to windmills to solar arrays, whereas backup capability is either a backup generator a UPS, or both, as recorded in the IST.

Table 38: Percentage of Facilities with an Alternate or Backup, by Census Region (Group A)a

\begin{tabular}{|l|r|r|r|r|}
\hline \multicolumn{1}{|c|}{ Group Name } & Midwest (\%) & Northeast (\%) & South (\%) & West (\%) \\
\hline Agriculture and Food & 67 & 75 & 80 & 40 \\
\hline Banking and Finance & 100 & 100 & 100 & 100 \\
\hline Commercial Facilities & 88 & 100 & 100 & 93 \\
\hline Communications & 100 & 100 & 100 & 96 \\
\hline Emergency Services & 100 & 93 & 90 & 100 \\
\hline Energy & 42 & 89 & 86 & 75 \\
\hline Government Facilities & 78 & 89 & 85 & 89 \\
\hline Healthcare and Public Health & 62 & 100 & 100 & 100 \\
\hline Manufacturing & 67 & 83 & 86 & 33 \\
\hline Transportation & 100 & 86 & 95 & 90 \\
\hline Water & 77 & 77 & 80 & 83 \\
\hline Processing, Packaging, and Production & 60 & 58 & 40 & 63 \\
\hline Banking and Credit & 63 & 100 & 100 & 91 \\
\hline Public Assembly & 93 & 100 & 85 & 100 \\
\hline Real Estate Facility & 84 & 90 & 100 & 83 \\
\hline Dam Project & 100 & 100 & 100 & 71 \\
\hline Electricity & 86 & 100 & 100 & 100 \\
\hline Petroleum & 75 & 80 & 74 & 22 \\
\hline Health Supporting Facility & 78 & 90 & 86 & 100 \\
\hline Mass Transit & 73 & 100 & 55 & 100 \\
\hline
\end{tabular}


Table 39: (Cont.)

\begin{tabular}{|c|c|c|c|c|}
\hline Group Name & Midwest (\%) & Northeast (\%) & South (\%) & West (\%) \\
\hline Road & 100 & 100 & 100 & 67 \\
\hline Wastewater Facility & ---- & 100 & 92 & 44 \\
\hline Water Treatment Facility & 93 & 81 & 90 & 93 \\
\hline Hotel or Motel & 93 & 100 & 96 & 100 \\
\hline Arena & 84 & 100 & 97 & 95 \\
\hline Community Organization Facility & 20 & 50 & 30 & 75 \\
\hline Stadium & 87 & 100 & 75 & 79 \\
\hline Store Retailer & 100 & 82 & 88 & 91 \\
\hline Hydropower Plant & 100 & 100 & 86 & 100 \\
\hline Water Retention Structure & 100 & 100 & 90 & 86 \\
\hline $\begin{array}{l}\text { Law Enforcement Administrative } \\
\text { Office/Headquarters }\end{array}$ & 100 & 100 & 100 & 94 \\
\hline Electricity Generation & 100 & 75 & 75 & 100 \\
\hline Electricity Transmission & 100 & 67 & 100 & 100 \\
\hline Higher Education Facility & 58 & 81 & 86 & 60 \\
\hline Pre-K-12 School & 27 & 64 & 47 & 37 \\
\hline Hospital & 100 & 100 & 94 & 100 \\
\hline Port & ---- & 100 & 67 & 50 \\
\hline Wastewater Treatment Plant & 89 & 83 & 86 & 88 \\
\hline Office Building - Stand Alone & 93 & 100 & 80 & 100 \\
\hline Distribution Substation & ----- & 57 & 100 & 67 \\
\hline Transmission Substation & 50 & 64 & 50 & 43 \\
\hline Office or Office Building Complex & 82 & 69 & 85 & 69 \\
\hline Critical Access Hospital & 100 & 100 & 100 & ---- \\
\hline Road Bridge & 100 & 50 & 91 & 100 \\
\hline Coal-fired Generator & 80 & ----- & 67 & 33 \\
\hline Agency Headquarters & 65 & 100 & 89 & 67 \\
\hline Judicial Chamber or Office & 64 & 80 & 89 & 88 \\
\hline $\begin{array}{l}\text { Private or Private Not-for-Profit General } \\
\text { Medical and Surgical Hospital }\end{array}$ & 100 & 100 & 100 & 100 \\
\hline $\begin{array}{l}\text { State, Local, or Tribal General Medical and } \\
\text { Surgical Hospital }\end{array}$ & 100 & 100 & 100 & 100 \\
\hline
\end{tabular}

${ }^{a}$ Groups with 30 or more sites are highlighted.

Table 40: Percentage of Facilities with an Alternate or Backup by Census Region (Group B) ${ }^{a}$

\begin{tabular}{|l|r|r|r|r|}
\hline \multicolumn{1}{|c|}{ Census Group Name } & Midwest (\%) & Northeast (\%) & South (\%) & West (\%) \\
\hline Agriculture and Food Census Group & 63 & 67 & 72 & 50 \\
\hline Healthcare and Public Health Census Group & 66 & 94 & 94 & 100 \\
\hline Transportation Census Group & 83 & 93 & 82 & 83 \\
\hline Water Census Group & 77 & 83 & 83 & 69 \\
\hline Lodging Facility Census Group & 93 & 100 & 97 & 94 \\
\hline Public Assembly Census Group & 58 & 86 & 76 & 96 \\
\hline Real Estate Facility Census Group & 88 & 94 & 91 & 94 \\
\hline Dam Project Census Group & 100 & 100 & 93 & 91 \\
\hline Electricity Census Group & 92 & 74 & 100 & 94 \\
\hline Petroleum Census Group & 75 & 80 & 74 & 22 \\
\hline Maritime Census Group & ---- & 100 & 76 & 50 \\
\hline Water Treatment Facility Census Group & 93 & 81 & 90 & 93 \\
\hline Arena Census Group & 84 & 100 & 97 & 95 \\
\hline Stadium Census Group & 87 & 100 & 75 & 79 \\
\hline Electricity Generation Census Group & 83 & 75 & 71 & 85 \\
\hline Higher Education Facility Census Group & 58 & 81 & 86 & 60 \\
\hline Pre-K-12 School Census Group & 27 & 64 & 47 & 37 \\
\hline
\end{tabular}


Table 41: (Cont.)

\begin{tabular}{|l|r|r|r|r|}
\hline \multicolumn{1}{|c|}{ Census Group Name } & Midwest (\%) & Northeast (\%) & South (\%) & West (\%) \\
\hline Hospital Census Group & 100 & 100 & 97 & 100 \\
\hline Wastewater Treatment Plant Census Group & 89 & 83 & 86 & 88 \\
\hline Transmission Substation Census Group & 50 & 64 & 50 & 43 \\
\hline Office or Office Building Complex Census Group & 71 & 76 & 88 & 76 \\
\hline Road Bridge Census Group & 100 & 50 & 91 & 100 \\
\hline $\begin{array}{l}\text { Private or Private Not-for-Profit General Medical } \\
\text { and Surgical Hospital Census Group }\end{array}$ & 100 & 100 & 100 & 100 \\
\hline
\end{tabular}

${ }^{a}$ Groups with 30 or more sites are highlighted.

The following sections will discuss characteristics of backup measures by census region. Table 28 shows the percentage of facilities that depend on external electrical power with both backup generators and UPSs across each region.

Table 42: Backup Capabilities by Census Region

\begin{tabular}{|c|c|c|c|}
\hline Group Name & $\begin{array}{c}\text { Percentage (\%) } \\
\text { with a Backup } \\
\text { Generator }\end{array}$ & $\begin{array}{l}\text { Percentage (\%) } \\
\text { with a UPS }\end{array}$ & $\begin{array}{c}\text { Percentage (\%) } \\
\text { with a Backup } \\
\text { Generator and } \\
\text { UPS }\end{array}$ \\
\hline Midwest & 68 & 56 & 52 \\
\hline Northeast & 83 & 65 & 64 \\
\hline South & 80 & 52 & 50 \\
\hline West & 75 & 58 & 56 \\
\hline
\end{tabular}

\subsubsection{Backup Generators by Census Region}

The survey does not explicitly collect information on alternate sources of power, type, or characteristics. The data collected captures characteristics of both backup generation and UPS capabilities. Tables 29 and 30 present the percentage of facilities for Group A and Group B, respectively, with an alternate or backup that have a backup generator. 
Table 43: Facilities with a Backup Generator by Census Region (Group A) ${ }^{\mathrm{a}}$

\begin{tabular}{|c|c|c|c|c|}
\hline Group Name & $\begin{array}{l}\text { Midwest } \\
(\%)\end{array}$ & $\begin{array}{l}\text { Northeast } \\
(\%)\end{array}$ & $\begin{array}{l}\text { South } \\
(\%)\end{array}$ & $\begin{array}{c}\text { West } \\
(\%)\end{array}$ \\
\hline Agriculture and Food & 67 & 75 & 80 & 40 \\
\hline Banking and Finance & 100 & 100 & 100 & 100 \\
\hline Commercial Facilities & 88 & 100 & 94 & 93 \\
\hline Communications & 100 & 100 & 100 & 96 \\
\hline Emergency Services & 100 & 93 & 90 & 100 \\
\hline Energy & 42 & 89 & 86 & 75 \\
\hline Government Facilities & 78 & 89 & 80 & 89 \\
\hline Healthcare and Public Health & 58 & 100 & 100 & 100 \\
\hline Manufacturing & 67 & 83 & 86 & 33 \\
\hline Transportation & 100 & 86 & 95 & 90 \\
\hline Water & 77 & 77 & 77 & 83 \\
\hline Processing, Packaging, and Production & 40 & 50 & 40 & 56 \\
\hline Banking and Credit & 63 & 100 & 100 & 91 \\
\hline Public Assembly & 85 & 95 & 83 & 95 \\
\hline Real Estate Facility & 79 & 90 & 100 & 83 \\
\hline Dam Project & 100 & 100 & 100 & 57 \\
\hline Electricity & 86 & 100 & 100 & 100 \\
\hline Petroleum & 50 & 70 & 71 & 22 \\
\hline Health Supporting Facility & 78 & 90 & 86 & 100 \\
\hline Mass Transit & 73 & 100 & 55 & 100 \\
\hline Road & 80 & 100 & 100 & 50 \\
\hline Wastewater Facility & ----- & 100 & 92 & 44 \\
\hline Water Treatment Facility & 93 & 81 & 88 & 93 \\
\hline Hotel or Motel & 93 & 100 & 96 & 100 \\
\hline Arena & 84 & 90 & 94 & 95 \\
\hline Community Organization Facility & 12 & 50 & 20 & 50 \\
\hline Stadium & 87 & 100 & 75 & 79 \\
\hline Store Retailer & 100 & 82 & 88 & 82 \\
\hline Hydropower Plant & 100 & 100 & 86 & 100 \\
\hline Water Retention Structure & 100 & 100 & 90 & 71 \\
\hline $\begin{array}{l}\text { Law Enforcement Administrative } \\
\text { Office/Headquarters }\end{array}$ & 100 & 100 & 100 & 94 \\
\hline Electricity Generation & 100 & 75 & 50 & 90 \\
\hline Electricity Transmission & 100 & 67 & 100 & 100 \\
\hline Higher Education Facility & 53 & 81 & 86 & 60 \\
\hline Pre-K-12 School & 23 & 60 & 37 & 37 \\
\hline Hospital & 100 & 100 & 94 & 100 \\
\hline Port & ----- & 100 & 59 & 25 \\
\hline Wastewater Treatment Plant & 89 & 78 & 86 & 88 \\
\hline Office Building - Stand Alone & 79 & 100 & 80 & 100 \\
\hline Distribution Substation & ----- & 57 & 100 & 0 \\
\hline Transmission Substation & 0 & 60 & 0 & 14 \\
\hline Office or Office Building Complex & 59 & 69 & 85 & 69 \\
\hline Critical Access Hospital & 100 & 100 & 100 & ----- \\
\hline Road Bridge & 100 & 50 & 91 & 100 \\
\hline Coal-fired Generator & 67 & ----- & 67 & 33 \\
\hline Agency Headquarters & 65 & 100 & 89 & 67 \\
\hline Judicial Chamber or Office & 64 & 80 & 89 & 69 \\
\hline $\begin{array}{l}\text { Private or Private Not-for-Profit General Medical } \\
\text { and Surgical Hospital }\end{array}$ & 100 & 100 & 100 & 100 \\
\hline $\begin{array}{l}\text { State, Local, or Tribal General Medical and } \\
\text { Surgical Hospital }\end{array}$ & 100 & 100 & 100 & 100 \\
\hline
\end{tabular}

${ }^{a}$ Groups with 30 or more sites are highlighted. 
Table 44: Facilities with a Backup Generator by Census Region (Group B) ${ }^{a}$

\begin{tabular}{|c|c|c|c|c|}
\hline Census Group Name & $\begin{array}{l}\text { Midwest } \\
(\%)\end{array}$ & $\begin{array}{l}\text { Northeast } \\
(\%)\end{array}$ & $\begin{array}{l}\text { South } \\
(\%)\end{array}$ & West (\%) \\
\hline Agriculture and Food Census Group & 53 & 63 & 72 & 47 \\
\hline Healthcare and Public Health Census Group & 63 & 94 & 94 & 100 \\
\hline Transportation Census Group & 79 & 93 & 82 & 78 \\
\hline Water Census Group & 77 & 83 & 81 & 69 \\
\hline Lodging Facility Census Group & 93 & 100 & 97 & 94 \\
\hline Public Assembly Census Group & 50 & 83 & 73 & 88 \\
\hline Real Estate Facility Census Group & 79 & 94 & 91 & 94 \\
\hline Dam Project Census Group & 100 & 100 & 93 & 85 \\
\hline Electricity Census Group & 92 & 74 & 100 & 81 \\
\hline Petroleum Census Group & 50 & 70 & 71 & 22 \\
\hline Maritime Census Group & ----- & 100 & 71 & 25 \\
\hline Water Treatment Facility Census Group & 93 & 81 & 88 & 93 \\
\hline Arena Census Group & 84 & 90 & 94 & 95 \\
\hline Stadium Census Group & 87 & 100 & 75 & 79 \\
\hline Electricity Generation Census Group & 72 & 75 & 57 & 77 \\
\hline Higher Education Facility Census Group & 53 & 81 & 86 & 60 \\
\hline Pre-K-12 School Census Group & 23 & 60 & 37 & 37 \\
\hline Hospital Census Group & 100 & 100 & 97 & 100 \\
\hline Wastewater Treatment Plant Census Group & 89 & 78 & 86 & 88 \\
\hline Transmission Substation Census Group & 0 & 60 & 0 & 14 \\
\hline Office or Office Building Complex Census Group & 62 & 76 & 88 & 68 \\
\hline Road Bridge Census Group & 100 & 50 & 91 & 100 \\
\hline $\begin{array}{l}\text { Private or Private Not-for-Profit General Medical } \\
\text { and Surgical Hospital Census Group }\end{array}$ & 100 & 100 & 100 & 100 \\
\hline
\end{tabular}

${ }^{a}$ Groups with 30 or more sites are highlighted.

For the census region/group combinations where there are 30 or more observations, and results are presented in the first column of Table 28, it seems that the Northeast and South census regions have more backup generator presence than the West or Midwest regions. As shown in Table 31, the average duration of backup generation for the South and Northeast regions also seems to be longer than in either the Midwest or the West. Although the survey does not collect information to support climate-related observations, length and duration of climactic events within each region might influence

Table 45: Backup Generation Duration by Census Region

\begin{tabular}{l|c}
$\begin{array}{c}\text { Census } \\
\text { Region }\end{array}$ & $\begin{array}{c}\text { Average } \\
\text { Duration } \\
\text { (in hours) }\end{array}$ \\
\hline Midwest & 364 \\
\hline Northeast & 464 \\
\hline South & 408 \\
\hline West & 141 \\
\hline
\end{tabular}
differences between the regions. Due to the existence of extreme outliers for duration in each region, the average duration for the regions varies more widely than the median duration across all regions, as shown in Figure 10. 


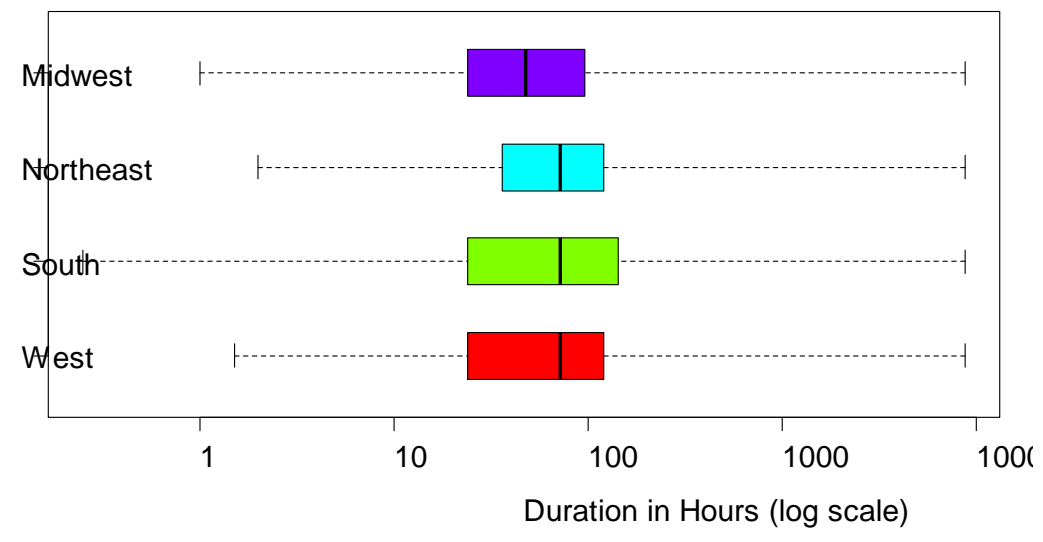

Figure 10: Backup Generation by Census Region

Some interesting insights are gained when the generator duration data is broken out further by facility study groups (Table 32) and census region study groups (Table 33).

Table 46: Average Duration of Backup Generator in Hours by Census Region (Group A) ${ }^{a}$

\begin{tabular}{|c|c|c|c|c|}
\hline Group Name & $\begin{array}{l}\text { Midwest } \\
(\%)\end{array}$ & $\begin{array}{c}\text { Northeast } \\
(\%)\end{array}$ & $\begin{array}{l}\text { South } \\
(\%)\end{array}$ & $\begin{array}{l}\text { West } \\
(\%)\end{array}$ \\
\hline Agriculture and Food & 301 & 1,057 & 581 & 1,147 \\
\hline Banking and Finance & 192 & 67 & 42 & 240 \\
\hline Commercial Facilities & 31 & 89 & 54 & 134 \\
\hline Communications & 74 & 396 & 171 & 254 \\
\hline Emergency Services & 147 & 740 & 1,212 & 114 \\
\hline Energy & 1,824 & 5 & 137 & 176 \\
\hline Government Facilities & 106 & 1,183 & 86 & 170 \\
\hline Healthcare and Public Health & 664 & 99 & 622 & 60 \\
\hline Manufacturing & 36 & 16 & 758 & 7 \\
\hline Transportation & 11 & 172 & 300 & 100 \\
\hline Water & 55 & 48 & 169 & 85 \\
\hline Processing, Packaging, and Production & 8 & 4,400 & 120 & 92 \\
\hline Banking and Credit & 85 & 203 & 105 & 64 \\
\hline Public Assembly & 68 & 494 & 72 & 104 \\
\hline Real Estate Facility & 73 & 63 & 63 & 88 \\
\hline Dam Project & 480 & 120 & 350 & 124 \\
\hline Electricity & 27 & 1,498 & 66 & 84 \\
\hline Petroleum & 15 & 6 & 77 & 16 \\
\hline Health Supporting Facility & 56 & 117 & 84 & 43 \\
\hline Mass Transit & 4,775 & 35 & 96 & 64 \\
\hline Road & 27 & 2,931 & 195 & 28 \\
\hline Wastewater Facility & ----- & 47 & 77 & 41 \\
\hline Water Treatment Facility & 493 & 319 & 317 & 429 \\
\hline Hotel or Motel & 38 & 85 & 92 & 818 \\
\hline Arena & 18 & 28 & 50 & 51 \\
\hline Community Organization Facility & 2,921 & 53 & 180 & 36 \\
\hline Stadium & 29 & 18 & 706 & 24 \\
\hline Store Retailer & 12 & 1,009 & 34 & 37 \\
\hline Hydropower Plant & 228 & 48 & 80 & 114 \\
\hline Water Retention Structure & 80 & 108 & 569 & 91 \\
\hline
\end{tabular}


Table 47: (Cont.)

\begin{tabular}{|c|c|c|c|c|}
\hline Group Name & $\begin{array}{l}\text { Midwest } \\
(\%)\end{array}$ & $\begin{array}{c}\text { Northeast } \\
\text { (\%) }\end{array}$ & $\begin{array}{l}\text { South } \\
(\%)\end{array}$ & $\begin{array}{l}\text { West } \\
(\%)\end{array}$ \\
\hline $\begin{array}{l}\text { Law Enforcement Administrative } \\
\text { Office/Headquarters }\end{array}$ & 100 & 24 & 56 & 77 \\
\hline Electricity Generation & 24 & 1,483 & 48 & 78 \\
\hline Electricity Transmission & 182 & 72 & 92 & 157 \\
\hline Higher Education Facility & 1,248 & 416 & 900 & 12 \\
\hline Pre-K-12 School & 3,358 & 2,602 & 2,977 & 124 \\
\hline Hospital & 55 & 132 & 141 & 143 \\
\hline Port & ----- & 60 & 606 & 48 \\
\hline Wastewater Treatment Plant & 82 & 110 & 358 & 871 \\
\hline Office Building - Stand Alone & 89 & 85 & 42 & 54 \\
\hline Distribution Substation & ----- & 96 & 12 & 0 \\
\hline Transmission Substation & 0 & 250 & 0 & 8 \\
\hline Office or Office Building Complex & 36 & 844 & 1,598 & 51 \\
\hline Critical Access Hospital & 69 & 115 & 72 & ---- \\
\hline Road Bridge & 24 & 72 & 1,039 & 103 \\
\hline Coal-fired Generator & 2,035 & ----- & 60 & 8 \\
\hline Agency Headquarters & 461 & 72 & 1,683 & 38 \\
\hline Judicial Chamber or Office & 36 & 2,256 & 1,151 & 66 \\
\hline $\begin{array}{l}\text { Private or Private Not-for-Profit General } \\
\text { Medical and Surgical Hospital }\end{array}$ & 155 & 250 & 89 & 126 \\
\hline $\begin{array}{l}\text { State, Local, or Tribal General Medical and } \\
\text { Surgical Hospital }\end{array}$ & 68 & 300 & 214 & 111 \\
\hline
\end{tabular}

${ }^{a}$ Groups with 30 or more sites are highlighted.

Table 48: Average Duration of Backup Generator in Hours by Census Region (Group B)a

\begin{tabular}{|l|r|r|r|r|}
\hline \multicolumn{1}{|c|}{ Census Group Name } & $\begin{array}{c}\text { Midwest } \\
(\%)\end{array}$ & $\begin{array}{c}\text { Northeast } \\
(\%)\end{array}$ & $\begin{array}{c}\text { South } \\
(\%)\end{array}$ & West (\%) \\
\hline Agriculture and Food Census Group & 184 & 2394 & 530 & 588 \\
\hline Healthcare and Public Health Census Group & 471 & 109 & 399 & 46 \\
\hline Transportation Census Group & 2772 & 767 & 142 & 79 \\
\hline Water Census Group & 55 & 48 & 140 & 75 \\
\hline Lodging Facility Census Group & 38 & 82 & 87 & 668 \\
\hline Public Assembly Census Group & 398 & 421 & 76 & 98 \\
\hline Real Estate Facility Census Group & 80 & 73 & 54 & 65 \\
\hline Dam Project Census Group & 196 & 96 & 401 & 111 \\
\hline Electricity Census Group & 98 & 690 & 70 & 123 \\
\hline Petroleum Census Group & 15 & 6 & 77 & 16 \\
\hline Maritime Census Group & $-1--$ & 60 & 542 & 48 \\
\hline Water Treatment Facility Census Group & 493 & 319 & 317 & 429 \\
\hline Arena Census Group & 18 & 28 & 50 & 51 \\
\hline Stadium Census Group & 29 & 18 & 706 & 24 \\
\hline Electricity Generation Census Group & 1,571 & 1483 & 54 & 71 \\
\hline Higher Education Facility Census Group & 1,248 & 416 & 900 & 12 \\
\hline Pre K - 12 School Census Group & 3,358 & 2,602 & 2,977 & 124 \\
\hline Hospital Census Group & 66 & 143 & 169 & 130 \\
\hline Wastewater Treatment Plant Census Group & 82 & 110 & 358 & 871 \\
\hline Transmission Substation Census Group & 0 & 250 & 0 & 8 \\
\hline Office or Office Building Complex Census Group & 203 & 979 & 1,480 & 53 \\
\hline Road Bridge Census Group & 24 & 72 & 1,039 & 103 \\
\hline Private or Private Not-for-Profit General Medical & 155 & 250 & 89 & 126 \\
\hline and Surgical Hospital Census Group & & & & \\
\hline
\end{tabular}

${ }^{a}$ Groups with 30 or more sites are highlighted. 
As discussed in Section 4.3.2, the duration of the backup generator is highly sensitive to the type of generator being used (see Tables 8 and 9). Table 34 displays the percentage of each type of backup generator and the average duration by census region. The West census region has a noticeably lower percentage of natural gas generators, and those they do have do not seem to last as long, on average, as in other regions. Although the Northeast and South census regions do not have the largest percentage of natural gas generators, their average duration is almost double the duration of the generators in the Midwest and over three times the duration of the generators in the West.

Table 49: Backup Generator Typea and Duration by Census Region

\begin{tabular}{|c|c|c|c|c|c|c|}
\hline Group Name & $\begin{array}{l}\text { Percent } \\
\text { (\%) Diesel }\end{array}$ & $\begin{array}{l}\text { Diesel } \\
\text { Average } \\
\text { Duration } \\
\text { (hours) }\end{array}$ & $\begin{array}{c}\text { Percent } \\
(\%) \\
\text { Natural } \\
\text { Gas }\end{array}$ & $\begin{array}{l}\text { Natural } \\
\text { Gas } \\
\text { Average } \\
\text { Duration } \\
\text { (hours) }\end{array}$ & $\begin{array}{c}\text { Percent } \\
(\%) \\
\text { Propane }\end{array}$ & $\begin{array}{c}\text { Propane } \\
\text { Average } \\
\text { Duration } \\
\text { (hours) }\end{array}$ \\
\hline Midwest & 82 & 181 & 16 & 2,651 & 2 & 1,386 \\
\hline Northeast & 86 & 85 & 11 & 4,802 & 3 & 50 \\
\hline South & 86 & 112 & 10 & 4,480 & 4 & 267 \\
\hline West & 88 & 78 & 5 & 1,962 & 7 & 141 \\
\hline
\end{tabular}

a The survey collects information on four fuel types: diesel, natural gas, propane and other. Less than 1 percent of all backup generators fall into the other category and the fuel type is not gathered explicitly, therefore these generators are removed from this study.

The duration of the backup generator can differ not only by purpose, but also by census region. Figure 11 shows the boxplots of backup generator duration by purpose and census region.

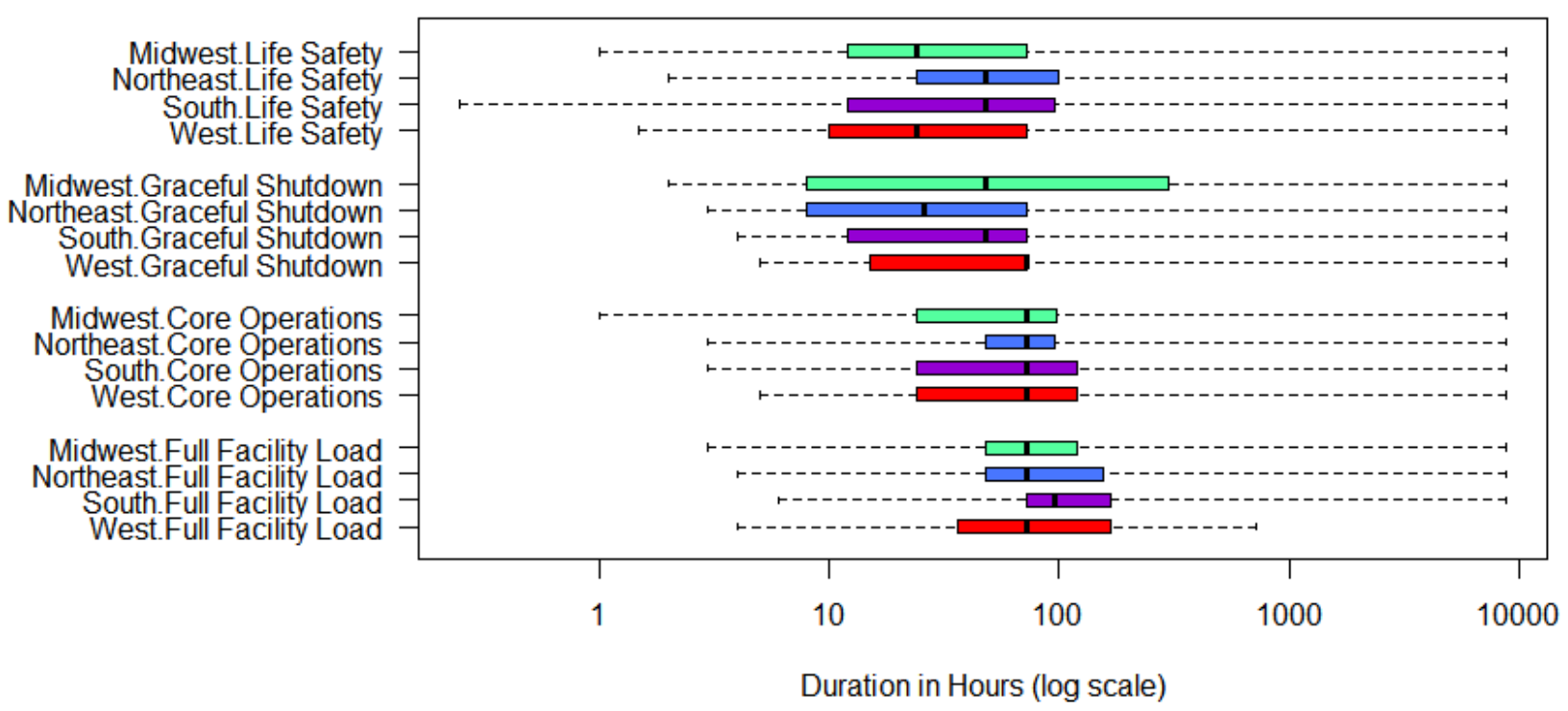

Figure 11: Boxplots of Backup Generator by Purpose and Census Region 


\subsection{UPS by Census Region}

Tables 35 and 36 show the percentage of Group A and Group B facilities, respectively, that have a UPS.

Table 50: Percent with a UPS by Census Region (Group A) ${ }^{\mathrm{a}}$

\begin{tabular}{|c|c|c|c|c|}
\hline Group Name & Midwest (\%) & Northeast (\%) & South (\%) & West (\%) \\
\hline Agriculture and Food & 67 & 75 & 20 & 30 \\
\hline Banking and Finance & 100 & 93 & 100 & 100 \\
\hline Commercial Facilities & 75 & 90 & 81 & 80 \\
\hline Communications & 100 & 100 & 100 & 96 \\
\hline Emergency Services & 78 & 80 & 63 & 67 \\
\hline Energy & 33 & 89 & 29 & 75 \\
\hline Government Facilities & 44 & 67 & 60 & 44 \\
\hline Healthcare and Public Health & 58 & 92 & 53 & 50 \\
\hline Manufacturing & 58 & 83 & 71 & 33 \\
\hline Transportation & 75 & 71 & 42 & 70 \\
\hline Water & 15 & 65 & 66 & 72 \\
\hline Processing, Packaging, and Production & 60 & 25 & 20 & 25 \\
\hline Banking and Credit & 50 & 100 & 80 & 91 \\
\hline Public Assembly & 70 & 71 & 49 & 75 \\
\hline Real Estate Facility & 58 & 50 & 46 & 17 \\
\hline Dam Project & 0 & 100 & 50 & 57 \\
\hline Electricity & 86 & 100 & 86 & 100 \\
\hline Petroleum & 75 & 70 & 57 & 22 \\
\hline Health Supporting Facility & 67 & 74 & 50 & 63 \\
\hline Mass Transit & 40 & 75 & 46 & 100 \\
\hline Road & 80 & 100 & 100 & 50 \\
\hline Wastewater Facility & ----- & 67 & 62 & 44 \\
\hline Water Treatment Facility & 84 & 70 & 58 & 74 \\
\hline Hotel or Motel & 47 & 40 & 71 & 83 \\
\hline Arena & 58 & 80 & 34 & 52 \\
\hline Community Organization Facility & 20 & 38 & 10 & 25 \\
\hline Stadium & 74 & 78 & 28 & 58 \\
\hline Store Retailer & 100 & 36 & 50 & 46 \\
\hline Hydropower Plant & 50 & 0 & 43 & 85 \\
\hline Water Retention Structure & 67 & 50 & 47 & 57 \\
\hline $\begin{array}{l}\text { Law Enforcement Administrative } \\
\text { Office/Headquarters }\end{array}$ & 50 & 100 & 100 & 82 \\
\hline Electricity Generation & 33 & 75 & 50 & 90 \\
\hline Electricity Transmission & 100 & 67 & 75 & 100 \\
\hline Higher Education Facility & 36 & 41 & 42 & 40 \\
\hline Pre-K-12 School & 17 & 35 & 28 & 17 \\
\hline Hospital & 100 & 63 & 78 & 78 \\
\hline Port & ----- & 20 & 33 & 25 \\
\hline Wastewater Treatment Plant & 67 & 61 & 41 & 75 \\
\hline Office Building - Stand Alone & 79 & 88 & 40 & 82 \\
\hline Distribution Substation & ----- & 43 & 100 & 67 \\
\hline Transmission Substation & 50 & 64 & 50 & 43 \\
\hline Office or Office Building Complex & 65 & 63 & 80 & 31 \\
\hline Critical Access Hospital & 69 & 60 & 50 & ----- \\
\hline Road Bridge & 0 & 50 & 91 & 0 \\
\hline Coal-fired Generator & 67 & ----- & 67 & 33 \\
\hline Agency Headquarters & 35 & 75 & 61 & 50 \\
\hline
\end{tabular}


Table 51: (Cont.)

\begin{tabular}{|c|c|c|c|c|}
\hline Group Name & Midwest (\%) & Northeast (\%) & South (\%) & West (\%) \\
\hline Judicial Chamber or Office & 55 & 40 & 56 & 63 \\
\hline $\begin{array}{l}\text { Private or Private Not-for-Profit General } \\
\text { Medical and Surgical Hospital }\end{array}$ & 97 & 89 & 68 & 77 \\
\hline $\begin{array}{l}\text { State, Local, or Tribal General Medical and } \\
\text { Surgical Hospital }\end{array}$ & 91 & 50 & 60 & 100 \\
\hline
\end{tabular}

${ }^{a}$ Groups with 30 or more sites are highlighted.

Table 52: Percent with a UPS by Census Region (Group B) ${ }^{\mathrm{a}}$

\begin{tabular}{|c|c|c|c|c|}
\hline Census Group Name & Midwest (\%) & Northeast (\%) & South (\%) & West (\%) \\
\hline Agriculture and Food Census Group & 63 & 50 & 20 & 28 \\
\hline Healthcare and Public Health Census Group & 60 & 81 & 52 & 60 \\
\hline Transportation Census Group & 54 & 79 & 74 & 67 \\
\hline Water Census Group & 15 & 65 & 65 & 62 \\
\hline Lodging Facility Census Group & 47 & 50 & 70 & 72 \\
\hline Public Assembly Census Group & 46 & 62 & 43 & 67 \\
\hline Real Estate Facility Census Group & 67 & 67 & 43 & 59 \\
\hline Dam Project Census Group & 50 & 50 & 48 & 74 \\
\hline Electricity Census Group & 92 & 68 & 83 & 94 \\
\hline Petroleum Census Group & 75 & 70 & 57 & 22 \\
\hline Maritime Census Group & ----- & 20 & 32 & 25 \\
\hline Water Treatment Facility Census Group & 88 & 70 & 58 & 74 \\
\hline Arena Census Group & 58 & 80 & 34 & 52 \\
\hline Stadium Census Group & 74 & 78 & 28 & 58 \\
\hline Electricity Generation Census Group & 61 & 75 & 57 & 77 \\
\hline Higher Education Facility Census Group & 36 & 41 & 42 & 40 \\
\hline Pre-K-12 School Census Group & 17 & 35 & 28 & 17 \\
\hline Hospital Census Group & 81 & 61 & 69 & 87 \\
\hline Wastewater Treatment Plant Census Group & 67 & 61 & 41 & 75 \\
\hline Transmission Substation Census Group & 50 & 64 & 50 & 43 \\
\hline $\begin{array}{l}\text { Office or Office Building Complex Census } \\
\text { Group }\end{array}$ & 51 & 60 & 66 & 49 \\
\hline Road Bridge Census Group & 0 & 50 & 91 & 0 \\
\hline $\begin{array}{l}\text { Private or Private Not-for-Profit General } \\
\text { Medical and Surgical Hospital Census Group }\end{array}$ & 97 & 89 & 68 & 77 \\
\hline
\end{tabular}

${ }^{a}$ Groups with 30 or more sites are highlighted.

Tables 37 and 38 show the average UPS duration by census region. 
Table 53: UPS Duration in Hours by Census Region (Group A) ${ }^{a}$

\begin{tabular}{|c|c|c|c|c|}
\hline Group Name & Midwest (\%) & Northeast (\%) & South (\%) & West (\%) \\
\hline Agriculture and Food & 133 & 1 & 6 & 4 \\
\hline Banking and Finance & 3 & 2 & 1 & 3 \\
\hline Commercial Facilities & 2 & 3 & 4 & 4 \\
\hline Communications & 1 & 5 & 16 & 7 \\
\hline Emergency Services & 3 & 2 & 4 & 5 \\
\hline Energy & 2 & 5 & 2 & 2 \\
\hline Government Facilities & 5 & 39 & 1 & 2 \\
\hline Healthcare and Public Health & 5 & 1 & 26 & 1 \\
\hline Manufacturing & 2 & 2 & 1 & 24 \\
\hline Transportation & 2 & 2 & 3 & 4 \\
\hline Water & 2 & 1 & 21 & 9 \\
\hline Processing, Packaging, and Production & 2 & 1 & 4 & 1 \\
\hline Banking and Credit & 4 & 6 & 1 & 4 \\
\hline Public Assembly & 4 & 3 & 15 & 13 \\
\hline Real Estate Facility & 2 & 18 & 1 & 1 \\
\hline Dam Project & 0 & 1 & 5 & 8 \\
\hline Electricity & 6 & 1 & 27 & 3 \\
\hline Petroleum & 9 & 2 & 21 & 2 \\
\hline Health Supporting Facility & 6 & 3 & 2 & 1 \\
\hline Mass Transit & 10 & 2 & 3 & 0 \\
\hline Road & 4 & 3 & 10 & 2 \\
\hline Wastewater Facility & ----- & 13 & 1 & 1 \\
\hline Water Treatment Facility & 10 & 3 & 2 & 20 \\
\hline Hotel or Motel & 11 & 2 & 11 & 5 \\
\hline Arena & 3 & 3 & 2 & 2 \\
\hline Community Organization Facility & 2 & 2 & 1 & 1 \\
\hline Stadium & 4 & 2 & 4 & 2 \\
\hline Store Retailer & 9 & 11 & 2 & 5 \\
\hline Hydropower Plant & 3 & 0 & 3 & 8 \\
\hline Water Retention Structure & 4 & 0 & 1 & 2 \\
\hline $\begin{array}{l}\text { Law Enforcement Administrative } \\
\text { Office/Headquarters }\end{array}$ & 3 & 4 & 1 & 3 \\
\hline Electricity Generation & 1 & 8 & 1 & 8 \\
\hline Electricity Transmission & 3 & 3 & 7 & 5 \\
\hline Higher Education Facility & 5 & 2 & 6 & 1 \\
\hline Pre-K-12 School & 9 & 2 & 1 & 3 \\
\hline Hospital & 4 & 1 & 3 & 3 \\
\hline Port & 0 & 6 & 3 & 1 \\
\hline Wastewater Treatment Plant & 2 & 4 & 4 & 2 \\
\hline Office Building - Stand Alone & 3 & 2 & 1 & 12 \\
\hline Distribution Substation & ----- & 5 & 1 & 36 \\
\hline Transmission Substation & 8 & 33 & 1 & 8 \\
\hline Office or Office Building Complex & 6 & 1 & 2 & 4 \\
\hline Critical Access Hospital & 2 & 4 & 24 & ----- \\
\hline Road Bridge & $---\cdot$ & 4 & 1 & 0 \\
\hline Coal-fired Generator & 6 & ---- & 3 & 1 \\
\hline Agency Headquarters & 2 & 3 & 1 & 1 \\
\hline Judicial Chamber or Office & 12 & 1 & 4 & 1 \\
\hline
\end{tabular}


Table 54: (Cont.)

\begin{tabular}{|c|c|c|c|c|}
\hline Group Name & Midwest (\%) & Northeast (\%) & South (\%) & West (\%) \\
\hline $\begin{array}{l}\text { Private or Private Not-for-Profit General } \\
\text { Medical and Surgical Hospital }\end{array}$ & 4 & 6 & 3 & 9 \\
\hline $\begin{array}{l}\text { State, Local, or Tribal General Medical and } \\
\text { Surgical Hospital }\end{array}$ & 2 & 4 & 5 & 9 \\
\hline
\end{tabular}

${ }^{a}$ Groups with 30 or more sites are highlighted.

Table 55: Average Duration of UPS in Hours by Census Region (Group B)

\begin{tabular}{|c|c|c|c|c|}
\hline Census Group Name & Midwest (\%) & Northeast (\%) & South (\%) & West (\%) \\
\hline Agriculture and Food Census Group & 67 & 1 & 5 & 3 \\
\hline Healthcare and Public Health Census Group & 5 & 2 & 16 & 1 \\
\hline Transportation Census Group & 6 & 2 & 7 & 3 \\
\hline Water Census Group & 2 & 4 & 15 & 7 \\
\hline Lodging Facility Census Group & 11 & 2 & 10 & 5 \\
\hline Public Assembly Census Group & 3 & 3 & 15 & 12 \\
\hline Real Estate Facility Census Group & 2 & 9 & 1 & 10 \\
\hline Dam Project Census Group & 4 & 0 & 3 & 7 \\
\hline Electricity Census Group & 4 & 3 & 18 & 9 \\
\hline Petroleum Census Group & 9 & 2 & 21 & 2 \\
\hline Maritime Census Group & ----- & 6 & 3 & 1 \\
\hline Water Treatment Facility Census Group & 10 & 3 & 2 & 20 \\
\hline Arena Census Group & 3 & 3 & 2 & 2 \\
\hline Stadium Census Group & 4 & 2 & 4 & 2 \\
\hline Electricity Generation Census Group & 6 & 8 & 2 & 7 \\
\hline Higher Education Facility Census Group & 5 & 2 & 6 & 1 \\
\hline Pre K - 12 School Census Group & 9 & 2 & 1 & 3 \\
\hline Hospital Census Group & 3 & 2 & 5 & 6 \\
\hline Wastewater Treatment Plant Census Group & 2 & 4 & 4 & 2 \\
\hline Transmission Substation Census Group & 8 & 33 & 1 & 8 \\
\hline $\begin{array}{l}\text { Office or Office Building Complex Census } \\
\text { Group }\end{array}$ & 4 & 2 & 2 & 2 \\
\hline Road Bridge Census Group & 0 & 4 & 1 & 0 \\
\hline $\begin{array}{l}\text { Private or Private Not-for-Profit General } \\
\text { Medical and Surgical Hospital Census Group }\end{array}$ & 4 & 6 & 3 & 9 \\
\hline
\end{tabular}

${ }^{a}$ Groups with 30 or more sites are highlighted.

\subsubsection{UPS Duration by Region}

Recall that a UPS provides power for a shorter duration than does a backup generator. Group B duration (Table 38) provides more insight into UPS duration by region due to the higher number of groupings with an adequate sample size. The Southern region has on average, a higher average duration than other regions in a number of study groups. 
Of the 1671 facilities that have a UPS, two of them stated that the UPS could provide power indefinitely (365 days), and another stated that the UPS could provide power for 100 days. The following analysis removes those three facilities from consideration because they were extreme outliers; no other facility had a UPS duration of more than 30 days.

Table 39 provides the UPS duration by region over the same five time groups defined in Section 4.4.1, and Figure 12 is a boxplot detailing the distribution of the duration of UPS for all regions, irrespective of time group. Figure 12 contains boxplots that compare the duration of UPS across regions for each time group.
Table 56: Distribution of UPS Duration by Census Region

\begin{tabular}{|l|c|}
\hline $\begin{array}{c}\text { Census } \\
\text { Region }\end{array}$ & $\begin{array}{c}\text { Average } \\
\text { Duration } \\
\text { (in hours) }\end{array}$ \\
\hline Midwest & 7 \\
\hline Northeast & 6 \\
\hline South & 7 \\
\hline West & 7 \\
\hline
\end{tabular}

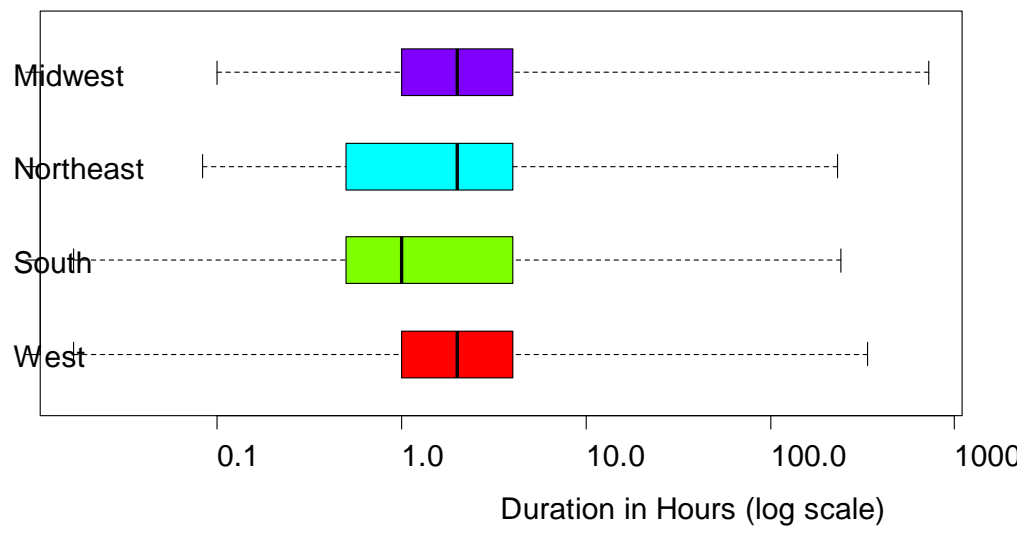

Figure 12: Duration of UPS across Regions

As shown in the second column of Table 39, the average UPS duration for each region is very similar. The boxplot adds information to the distributions by region; notice the median for the South is lower than that in the other three regions, although it is difficult to determine if there is a statistical difference. Also note that the distribution extremes skew the averages from the mean. The median times and standard deviations for each region are shown in Table 40.

Table 57: Average and Median UPS Duration by Census Region

\begin{tabular}{|l|c|c|}
$\begin{array}{c}\text { Census } \\
\text { Region }\end{array}$ & $\begin{array}{c}\text { Average } \\
\text { Duration } \\
\text { (in hours) }\end{array}$ & $\begin{array}{c}\text { Median Duration } \\
\text { (in Hours) }\end{array}$ \\
\hline Midwest & 7 & 2 \\
\hline Northeast & 6 & 2 \\
\hline South & 7 & 1 \\
\hline West & 7 & 2 \\
\hline
\end{tabular}




\subsubsection{UPS Purpose by Region}

The complexity of the interactions between study groups, census regions, and UPS purpose make displays of the information in tables very cumbersome. Because study groups are broken into census regions and then further into purpose, the number of facilities within each study group becomes very small. Figure 13 illustrates the breakout of UPS purpose by census region.
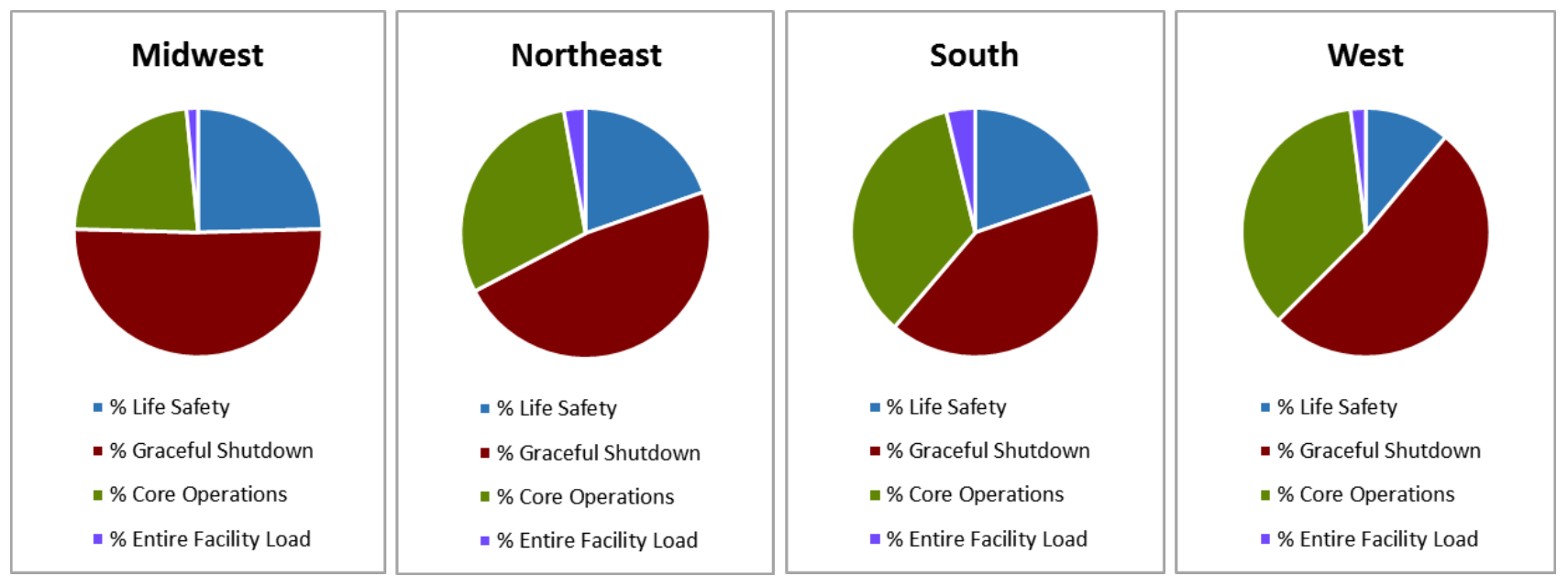

Figure 13: Purpose of UPS by Census Region

Tables 41 through 44 contain the percentage of Group A facilities that have a UPS, organized by census region, with one table per UPS purpose.

Table 58: Percent of Facilities with UPS by Census Region (Group A) - UPS Purpose: Life Safetya

\begin{tabular}{|c|c|c|c|c|}
\hline Group Name & Midwest (\%) & Northeast (\%) & South (\%) & West (\%) \\
\hline Agriculture and Food & 1 & 0 & 0 & 0 \\
\hline Banking and Finance & 0 & 0 & 2 & 0 \\
\hline Commercial Facilities & 1 & 1 & 4 & 5 \\
\hline Communications & 0 & 0 & 4 & 0 \\
\hline Emergency Services & 0 & 1 & 0 & 0 \\
\hline Energy & 2 & 0 & 0 & 0 \\
\hline Government Facilities & 2 & 0 & 1 & 8 \\
\hline Healthcare and Public Health & 6 & 1 & 2 & 0 \\
\hline Manufacturing & 2 & 1 & 1 & 3 \\
\hline Transportation & 0 & 1 & 1 & 0 \\
\hline Water & 0 & 0 & 5 & 0 \\
\hline Processing, Packaging, and Production & 0 & 1 & 0 & 0 \\
\hline Banking and Credit & 0 & 1 & 1 & 0 \\
\hline Public Assembly & 7 & 6 & 10 & 8 \\
\hline Real Estate Facility & 3 & 4 & 2 & 0 \\
\hline Dam Project & 0 & 0 & 1 & 0 \\
\hline Electricity & --- & ---- & ---- & ---- \\
\hline
\end{tabular}


Table 59: (Cont.)

\begin{tabular}{|c|c|c|c|c|}
\hline Group Name & Midwest (\%) & Northeast (\%) & South (\%) & West $(\%)$ \\
\hline Petroleum & 0 & 0 & 2 & 0 \\
\hline Health Supporting Facility & 2 & 3 & 0 & 3 \\
\hline Mass Transit & 0 & 4 & 0 & 0 \\
\hline Road & 0 & 0 & 2 & 0 \\
\hline Wastewater Facility & ----- & ---- & --- & ---- \\
\hline Water Treatment Facility & 11 & 3 & 4 & 0 \\
\hline Hotel or Motel & 3 & 1 & 9 & 10 \\
\hline Arena & 2 & 3 & 4 & 13 \\
\hline Community Organization Facility & 3 & 4 & 1 & 0 \\
\hline Stadium & 2 & 4 & 7 & 5 \\
\hline Store Retailer & 1 & 4 & 1 & 5 \\
\hline Hydropower Plant & 1 & 0 & 0 & 5 \\
\hline Water Retention Structure & 0 & 0 & 5 & 0 \\
\hline $\begin{array}{l}\text { Law Enforcement Administrative } \\
\text { Office/Headquarters }\end{array}$ & 2 & 0 & 0 & 0 \\
\hline Electricity Generation & 0 & 3 & 0 & 3 \\
\hline Electricity Transmission & ---- & --- & ---- & ---- \\
\hline Higher Education Facility & 8 & 4 & 2 & 0 \\
\hline Pre-K-12 School & 7 & 3 & 6 & 10 \\
\hline Hospital & 4 & 1 & 6 & 5 \\
\hline Port & 0 & 1 & 1 & 0 \\
\hline Wastewater Treatment Plant & 0 & 1 & 2 & 0 \\
\hline Office Building - Stand Alone & 2 & 3 & 0 & 10 \\
\hline Distribution Substation & ---- & ---- & ---- & --- \\
\hline Transmission Substation & 0 & 1 & 0 & 0 \\
\hline Office or Office Building Complex & 0 & 1 & 2 & 3 \\
\hline Critical Access Hospital & 7 & 1 & 0 & 0 \\
\hline Road Bridge & 0 & 0 & 1 & 0 \\
\hline Coal-fired Generator & 2 & 0 & 1 & 0 \\
\hline Agency Headquarters & 1 & 3 & 0 & 3 \\
\hline Judicial Chamber or Office & 1 & 0 & 1 & 0 \\
\hline $\begin{array}{l}\text { Private or Private Not-for-Profit General } \\
\text { Medical and Surgical Hospital }\end{array}$ & 10 & 29 & 10 & 3 \\
\hline $\begin{array}{l}\text { State, Local, or Tribal General Medical and } \\
\text { Surgical Hospital }\end{array}$ & 2 & 1 & 1 & 0 \\
\hline
\end{tabular}

${ }^{a}$ Groups with 30 or more sites are highlighted. 
Table 60: Percent of Facilities with UPS by Census Region (Group A) - UPS Purpose: Graceful Shutdowna

\begin{tabular}{|c|c|c|c|c|}
\hline Group Name & Midwest (\%) & Northeast (\%) & South (\%) & West (\%) \\
\hline Agriculture and Food & 2 & 3 & 2 & 2 \\
\hline Banking and Finance & 3 & 3 & 1 & 0 \\
\hline Commercial Facilities & 2 & 3 & 3 & 1 \\
\hline Communications & 0 & 0 & 1 & 6 \\
\hline Emergency Services & 1 & 2 & 2 & 1 \\
\hline Energy & 0 & 2 & 0 & 2 \\
\hline Government Facilities & 0 & 0 & 2 & 1 \\
\hline Healthcare and Public Health & 4 & 6 & 2 & 0 \\
\hline Manufacturing & 2 & 2 & 4 & 0 \\
\hline Transportation & 1 & 1 & 2 & 2 \\
\hline Water & 0 & 4 & 2 & 4 \\
\hline Processing, Packaging, and Production & 2 & 1 & 0 & 2 \\
\hline Banking and Credit & 2 & 1 & 2 & 2 \\
\hline Public Assembly & 4 & 4 & 5 & 6 \\
\hline Real Estate Facility & 3 & 1 & 0 & 1 \\
\hline Dam Project & 0 & 1 & 1 & 0 \\
\hline Electricity & 0 & 2 & 0 & 1 \\
\hline Petroleum & 1 & 3 & 3 & 1 \\
\hline Health Supporting Facility & 0 & 3 & 0 & 2 \\
\hline Mass Transit & 1 & 0 & 1 & 1 \\
\hline Road & 1 & 1 & 3 & 1 \\
\hline Wastewater Facility & 0 & 1 & 0 & 3 \\
\hline Water Treatment Facility & 2 & 10 & 4 & 7 \\
\hline Hotel or Motel & 1 & 1 & 4 & 3 \\
\hline Arena & 2 & 2 & 2 & 3 \\
\hline Community Organization Facility & 1 & 0 & 0 & 1 \\
\hline Stadium & 4 & 2 & 2 & 5 \\
\hline Store Retailer & 1 & 1 & 1 & 2 \\
\hline Hydropower Plant & 0 & 0 & 1 & 3 \\
\hline Water Retention Structure & 0 & 1 & 2 & 2 \\
\hline $\begin{array}{l}\text { Law Enforcement Administrative } \\
\text { Office/Headquarters }\end{array}$ & 1 & 1 & 0 & 4 \\
\hline Electricity Generation & 0 & 2 & 1 & 2 \\
\hline Electricity Transmission & 0 & 1 & 0 & 1 \\
\hline Higher Education Facility & 6 & 4 & 5 & 1 \\
\hline Pre-K-12 School & 3 & 6 & 10 & 4 \\
\hline Hospital & 2 & 4 & 2 & 2 \\
\hline Port & 0 & 0 & 1 & 1 \\
\hline Wastewater Treatment Plant & 2 & 5 & 4 & 7 \\
\hline Office Building - Stand Alone & 3 & 2 & 1 & 2 \\
\hline Distribution Substation & ----- & ---- & ---- & $-\ldots$ \\
\hline Transmission Substation & 0 & 1 & 0 & 1 \\
\hline Office or Office Building Complex & 4 & 4 & 5 & 1 \\
\hline Critical Access Hospital & 5 & 1 & 0 & 0 \\
\hline Road Bridge & 0 & 0 & 3 & 0 \\
\hline Coal-fired Generator & 4 & 0 & 0 & 1 \\
\hline Agency Headquarters & 2 & 0 & 4 & 1 \\
\hline Judicial Chamber or Office & 2 & 1 & 2 & 4 \\
\hline $\begin{array}{l}\text { Private or Private Not-for-Profit General } \\
\text { Medical and Surgical Hospital }\end{array}$ & 9 & 11 & 2 & 3 \\
\hline $\begin{array}{l}\text { State, Local, or Tribal General Medical and } \\
\text { Surgical Hospital }\end{array}$ & 4 & 0 & 4 & 3 \\
\hline
\end{tabular}

${ }^{a}$ Groups with 30 or more sites are highlighted. 
Table 61: Percent of Facilities with UPS by Census Region (Group A) - UPS Purpose: Core Operations ${ }^{a}$

\begin{tabular}{|c|c|c|c|c|}
\hline Group Name & Midwest (\%) & Northeast (\%) & South (\%) & West (\%) \\
\hline Agriculture and Food & 0 & 3 & 0 & 2 \\
\hline Banking and Finance & 0 & 4 & 2 & 1 \\
\hline Commercial Facilities & 1 & 2 & 1 & 6 \\
\hline Communications & 2 & 2 & 9 & 7 \\
\hline Emergency Services & 4 & 5 & 3 & 3 \\
\hline Energy & 1 & 3 & 2 & 0 \\
\hline Government Facilities & 1 & 5 & 3 & 0 \\
\hline Healthcare and Public Health & 0 & 0 & 1 & 1 \\
\hline Manufacturing & 1 & 1 & 1 & 0 \\
\hline Transportation & 0 & 2 & 2 & 2 \\
\hline Water & 0 & 3 & 6 & 11 \\
\hline Processing, Packaging, and Production & 1 & 0 & 1 & 0 \\
\hline Banking and Credit & 3 & 3 & 6 & 5 \\
\hline Public Assembly & 3 & 3 & 3 & 1 \\
\hline Real Estate Facility & 2 & 1 & 1 & 0 \\
\hline Dam Project & 0 & 0 & 3 & 3 \\
\hline Electricity & 7 & 2 & 2 & 3 \\
\hline Petroleum & 1 & 1 & 6 & 0 \\
\hline Health Supporting Facility & 3 & 4 & 4 & 0 \\
\hline Mass Transit & 3 & 0 & 1 & 0 \\
\hline Road & 1 & 2 & 2 & 0 \\
\hline Wastewater Facility & 0 & 3 & 4 & 1 \\
\hline Water Treatment Facility & 23 & 10 & 9 & 6 \\
\hline Hotel or Motel & 1 & 0 & 1 & 1 \\
\hline Arena & 5 & 1 & 2 & 0 \\
\hline Community Organization Facility & ---- & --- & --- & ---- \\
\hline Stadium & 7 & 0 & 1 & 2 \\
\hline Store Retailer & ---- & --- & --- & --- \\
\hline Hydropower Plant & 0 & 0 & 1 & 7 \\
\hline Water Retention Structure & 2 & 0 & 0 & 1 \\
\hline $\begin{array}{l}\text { Law Enforcement Administrative } \\
\text { Office/Headquarters }\end{array}$ & 1 & 0 & 2 & 6 \\
\hline Electricity Generation & 1 & 1 & 0 & 4 \\
\hline Electricity Transmission & 4 & 3 & 2 & 4 \\
\hline Higher Education Facility & 1 & 3 & 1 & 1 \\
\hline Pre-K-12 School & 0 & 6 & 1 & 0 \\
\hline Hospital & 2 & 2 & 2 & 1 \\
\hline Port & 0 & 0 & 3 & 0 \\
\hline Wastewater Treatment Plant & 1 & 3 & 3 & 5 \\
\hline Office Building - Stand Alone & 1 & 2 & 1 & 2 \\
\hline Distribution Substation & 0 & 3 & 1 & 2 \\
\hline Transmission Substation & 1 & 11 & 0 & 2 \\
\hline Office or Office Building Complex & 2 & 2 & 2 & 1 \\
\hline Critical Access Hospital & ---- & ---- & ---- & ---- \\
\hline Road Bridge & 0 & 1 & 2 & 0 \\
\hline Coal-fired Generator & --- & --- & --- & --- \\
\hline Agency Headquarters & 1 & 1 & 1 & 2 \\
\hline Judicial Chamber or Office & 0 & 0 & 2 & 2 \\
\hline $\begin{array}{l}\text { Private or Private Not-for-Profit General } \\
\text { Medical and Surgical Hospital }\end{array}$ & 7 & 5 & 3 & 3 \\
\hline $\begin{array}{l}\text { State, Local, or Tribal General Medical and } \\
\text { Surgical Hospital }\end{array}$ & 0 & 0 & 0 & 1 \\
\hline
\end{tabular}

${ }^{a}$ Groups with 30 or more sites are highlighted. 
Table 62: Percent of Facilities with UPS by Census Region (Group A) - UPS Purpose: Entire Facility Loada

\begin{tabular}{|c|c|c|c|c|}
\hline Group Name & Midwest (\%) & Northeast (\%) & South (\%) & West (\%) \\
\hline Agriculture and Food & 0 & 9 & 0 & 0 \\
\hline Banking and Finance & 0 & 18 & 5 & 0 \\
\hline Commercial Facilities & ---- & ---- & ---- & --- \\
\hline Communications & 17 & 0 & 15 & 29 \\
\hline Emergency Services & 0 & 18 & 15 & 0 \\
\hline Energy & ---- & --- & --- & ---- \\
\hline Government Facilities & ---- & ---- & ---- & ---- \\
\hline Healthcare and Public Health & 17 & 0 & 0 & 0 \\
\hline Manufacturing & ---- & ---- & ---- & ---- \\
\hline Transportation & ---- & ---- & ---- & --- \\
\hline Water & 17 & 0 & 5 & 0 \\
\hline Processing, Packaging, and Production & ---- & ---- & ---- & --- \\
\hline Banking and Credit & 17 & 0 & 0 & 0 \\
\hline Public Assembly & ---- & ---- & ---- & --- \\
\hline Real Estate Facility & ---- & ---- & ---- & --- \\
\hline Dam Project & --- & --- & --- & --- \\
\hline Electricity & 0 & 9 & 5 & 14 \\
\hline Petroleum & ---- & ---- & ---- & ---- \\
\hline Health Supporting Facility & 0 & 9 & 0 & 0 \\
\hline Mass Transit & 0 & 0 & 5 & 0 \\
\hline Road & 0 & 0 & 15 & 14 \\
\hline Wastewater Facility & --- & --- & --- & --- \\
\hline Water Treatment Facility & 17 & 9 & 5 & 0 \\
\hline Hotel or Motel & ---- & ---- & ---- & ---- \\
\hline Arena & 0 & 9 & 0 & 14 \\
\hline Community Organization Facility & ---- & --- & --- & --- \\
\hline Stadium & 0 & 0 & 0 & 14 \\
\hline Store Retailer & --- & --- & --- & --- \\
\hline Hydropower Plant & ---- & ---- & ---- & ---- \\
\hline Water Retention Structure & ---- & ---- & ---- & ---- \\
\hline $\begin{array}{l}\text { Law Enforcement Administrative } \\
\text { Office/Headquarters }\end{array}$ & ---- & --- & --- & ---- \\
\hline Electricity Generation & --- & ---- & ---- & --- \\
\hline Electricity Transmission & ---- & ---- & ---- & ---- \\
\hline Higher Education Facility & ---- & ---- & ---- & --- \\
\hline Pre-K-12 School & 0 & 0 & 5 & 0 \\
\hline Hospital & ---- & ---- & ---- & ---- \\
\hline Port & ---- & ---- & ---- & --- \\
\hline Wastewater Treatment Plant & 0 & 0 & 5 & 0 \\
\hline Office Building - Stand Alone & 17 & 0 & 0 & 0 \\
\hline Distribution Substation & --- & --- & --- & --- \\
\hline Transmission Substation & 0 & 9 & 5 & 0 \\
\hline Office or Office Building Complex & --- & --- & --- & --- \\
\hline Critical Access Hospital & ---- & ---- & ---- & ---- \\
\hline Road Bridge & --- & --- & --- & --- \\
\hline Coal-fired Generator & ---- & ---- & ---- & ---- \\
\hline Agency Headquarters & --- & ---- & ---- & --- \\
\hline Judicial Chamber or Office & ---- & ---- & ---- & ---- \\
\hline $\begin{array}{l}\text { Private or Private Not-for-Profit General } \\
\text { Medical and Surgical Hospital }\end{array}$ & 7 & 5 & 3 & 3 \\
\hline $\begin{array}{l}\text { State, Local, or Tribal General Medical and } \\
\text { Surgical Hospital }\end{array}$ & --- & --- & --- & --- \\
\hline
\end{tabular}

${ }^{a}$ Groups with 30 or more sites are highlighted. 
Table 45 through 48 contain the percent of Group B facilities that have a UPS, organized by census region, with one table per UPS purpose.

Table 63: Percent of Facilities with UPS by Census Region (Group B) - UPS Purpose: Life Safetya

\begin{tabular}{|l|c|c|c|c|}
\hline \multicolumn{1}{|c|}{ Census Group Name } & Midwest (\%) & Northeast (\%) & South (\%) & West (\%) \\
\hline Agriculture and Food Census Group & 1 & 1 & 0 & 0 \\
\hline Healthcare and Public Health Census Group & 8 & 4 & 2 & 3 \\
\hline Transportation Census Group & 0 & 5 & 3 & 0 \\
\hline Water Census Group & 0 & 0 & 5 & 0 \\
\hline Lodging Facility Census Group & 3 & 1 & 10 & 13 \\
\hline Public Assembly Census Group & 10 & 10 & 11 & 8 \\
\hline Real Estate Facility Census Group & 5 & 6 & 2 & 10 \\
\hline Dam Project Census Group & 1 & 0 & 6 & 5 \\
\hline Electricity Census Group & -- & -- & -- & - \\
\hline Petroleum Census Group & 0 & 0 & 2 & 0 \\
\hline Maritime Census Group & 0 & 1 & 1 & 0 \\
\hline Water Treatment Facility Census Group & 11 & 3 & 4 & 0 \\
\hline Arena Census Group & 2 & 3 & 4 & 13 \\
\hline Stadium Census Group & 2 & 4 & 7 & 5 \\
\hline Electricity Generation Census Group & 2 & 3 & 1 & 0 \\
\hline Higher Education Facility Census Group & 8 & 4 & 2 & 10 \\
\hline Pre-K-12 School Census Group & 7 & 3 & 6 & 5 \\
\hline Hospital Census Group & 13 & 4 & 7 & 0 \\
\hline Wastewater Treatment Plant Census Group & 0 & 1 & 2 & 0 \\
\hline Transmission Substation Census Group & 0 & 1 & 0 & 5 \\
\hline Office or Office Building Complex Census Group & 2 & 4 & 3 & 0 \\
\hline Road Bridge Census Group & 0 & 0 & 1 & 3 \\
\hline Private or Private Not-for-Profit General Medical & 10 & 29 & 10 & \\
\hline and Surgical Hospital Census Group & & & & 3 \\
\hline
\end{tabular}

${ }^{a}$ Groups with 30 or more sites are highlighted.

Table 64: Percent of Facilities with UPS by Census Region (Group B) - UPS Purpose: Graceful Shutdowna

\begin{tabular}{|l|c|c|c|c|}
\hline \multicolumn{1}{|c|}{ Census Group Name } & Midwest (\%) & Northeast (\%) & South (\%) & West (\%) \\
\hline Agriculture and Food Census Group & 5 & 4 & 2 & 4 \\
\hline Healthcare and Public Health Census Group & 4 & 9 & 2 & 2 \\
\hline Transportation Census Group & 4 & 2 & 6 & 4 \\
\hline Water Census Group & 0 & 5 & 3 & 7 \\
\hline Lodging Facility Census Group & 1 & 2 & 4 & 3 \\
\hline Public Assembly Census Group & 5 & 4 & 5 & 7 \\
\hline Real Estate Facility Census Group & 6 & 2 & 2 & 2 \\
\hline Dam Project Census Group & 0 & 1 & 4 & 4 \\
\hline Electricity Census Group & 0 & 2 & 0 & 2 \\
\hline Petroleum Census Group & 1 & 3 & 3 & 1 \\
\hline Maritime Census Group & 0 & 0 & 2 & 1 \\
\hline Water Treatment Facility Census Group & 2 & 10 & 4 & 7 \\
\hline Arena Census Group & 2 & 2 & 2 & 3 \\
\hline Stadium Census Group & 4 & 2 & 2 & 5 \\
\hline Electricity Generation Census Group & 4 & 2 & 1 & 2 \\
\hline Higher Education Facility Census Group & 6 & 4 & 5 & 1 \\
\hline Pre-K-12 School Census Group & 3 & 6 & 10 & 4 \\
\hline Hospital Census Group & 11 & 5 & 6 & 5 \\
\hline Wastewater Treatment Plant Census Group & 2 & 5 & 4 & 7 \\
\hline Transmission Substation Census Group & 0 & 1 & 0 & 1 \\
\hline
\end{tabular}


Table 65: (Cont.)

\begin{tabular}{|l|c|c|c|c|}
\multicolumn{1}{|c|}{ Census Group Name } & Midwest (\%) & Northeast (\%) & South (\%) & West (\%) \\
\hline Office or Office Building Complex Census Group & 9 & 5 & 11 & 6 \\
\hline Road Bridge Census Group & 0 & 0 & 3 & 0 \\
\hline $\begin{array}{l}\text { Private or Private Not-for-Profit General Medical } \\
\text { and Surgical Hospital Census Group }\end{array}$ & 9 & 11 & 2 & 3 \\
\hline
\end{tabular}

${ }^{a}$ Groups with 30 or more sites are highlighted.

Table 66: Percent of Facilities with UPS by Census Region (Group B) - UPS Purpose: Core Operations ${ }^{a}$

\begin{tabular}{|c|c|c|c|c|}
\hline Census Group Name & Midwest (\%) & Northeast (\%) & South (\%) & West (\%) \\
\hline Agriculture and Food Census Group & 1 & 3 & 1 & 2 \\
\hline Healthcare and Public Health Census Group & 3 & 4 & 5 & 1 \\
\hline Transportation Census Group & 4 & 3 & 3 & 2 \\
\hline Water Census Group & 0 & 5 & 10 & 12 \\
\hline Lodging Facility Census Group & 1 & 0 & 1 & 2 \\
\hline Public Assembly Census Group & 3 & 3 & 3 & 1 \\
\hline Real Estate Facility Census Group & 3 & 3 & 2 & 2 \\
\hline Dam Project Census Group & 2 & 0 & 4 & 11 \\
\hline Electricity Census Group & 11 & 7 & 4 & 9 \\
\hline Petroleum Census Group & 1 & 1 & 6 & 0 \\
\hline Maritime Census Group & 0 & 0 & 4 & 0 \\
\hline Water Treatment Facility Census Group & 23 & 10 & 9 & 6 \\
\hline Arena Census Group & 5 & 1 & 2 & 0 \\
\hline Stadium Census Group & 7 & 0 & 1 & 2 \\
\hline Electricity Generation Census Group & 1 & 1 & 0 & 4 \\
\hline Higher Education Facility Census Group & 1 & 3 & 1 & 1 \\
\hline Pre K - 12 School Census Group & 0 & 6 & 1 & 0 \\
\hline Hospital Census Group & 2 & 2 & 2 & 2 \\
\hline Wastewater Treatment Plant Census Group & 1 & 3 & 3 & 5 \\
\hline Transmission Substation Census Group & 1 & 11 & 0 & 2 \\
\hline Office or Office Building Complex Census Group & 3 & 3 & 5 & 6 \\
\hline Road Bridge Census Group & 0 & 1 & 2 & 0 \\
\hline $\begin{array}{l}\text { Private or Private Not-for-Profit General Medical } \\
\text { and Surgical Hospital Census Group }\end{array}$ & 7 & 5 & 3 & 3 \\
\hline
\end{tabular}

${ }^{a}$ Groups with 30 or more sites are highlighted.

Table 67: Percent of Facilities with UPS by Census Region (Group B) - UPS Purpose: Entire Facility Loada

\begin{tabular}{|l|c|c|c|c|}
\multicolumn{1}{c}{ Census Group Name } & Midwest (\%) & Northeast (\%) & South (\%) & West (\%) \\
\hline Agriculture and Food Census Group & 0 & 9 & 0 & 0 \\
\hline Healthcare and Public Health Census Group & 17 & 9 & 0 & 0 \\
\hline Transportation Census Group & 0 & 0 & 20 & 14 \\
\hline Water Census Group & 17 & 0 & 5 & 0 \\
\hline Lodging Facility Census Group & -- & -- & -- & - \\
\hline Public Assembly Census Group & -- & -- & -- & - \\
\hline Real Estate Facility Census Group & 17 & 0 & 0 & 0 \\
\hline Dam Project Census Group & 0 & 0 & 0 & 14 \\
\hline Electricity Census Group & 0 & 9 & 5 & 14 \\
\hline Petroleum Census Group & -- & -- & -- & - \\
\hline Maritime Census Group & -- & -- & -- & - \\
\hline Water Treatment Facility Census Group & 17 & 9 & 5 & 0 \\
\hline Arena Census Group & 0 & 9 & 0 & 14 \\
\hline Stadium Census Group & 0 & 0 & 0 & 14 \\
\hline
\end{tabular}


Table 68: (Cont.)

\begin{tabular}{|l|c|c|c|c|}
\multicolumn{1}{c|}{ Census Group Name } & Midwest (\%) & Northeast (\%) & South (\%) & West (\%) \\
\hline Electricity Generation Census Group & -- & -- & -- \\
\hline Higher Education Facility Census Group & -- & -- & -- \\
\hline $\begin{array}{l}\text { Pre-K-12 School Census Group } \\
\text { Hospital Census Group }\end{array}$ & 0 & -- & 5 & 0 \\
\hline Wastewater Treatment Plant Census Group & 0 & -- & -- & 0 \\
\hline Transmission Substation Census Group & 0 & - & 5 & 0 \\
\hline Office or Office Building Complex Census Group & -- & -- & -- \\
\hline Road Bridge Census Group & -- & -- & -- \\
\hline $\begin{array}{l}\text { Private or Private Not-for-Profit General Medical } \\
\text { and Surgical Hospital Census Group }\end{array}$ & 0 & - & 0 & 0 \\
\hline
\end{tabular}

${ }^{a}$ Groups with 30 or more sites are highlighted.

Due to the extremely small sample size, as demonstrated in the tables above, the distribution of UPS duration by purpose for each census region is shown at the aggregate level rather than by study group. Figure 14 depicts UPS duration by purpose and census region.

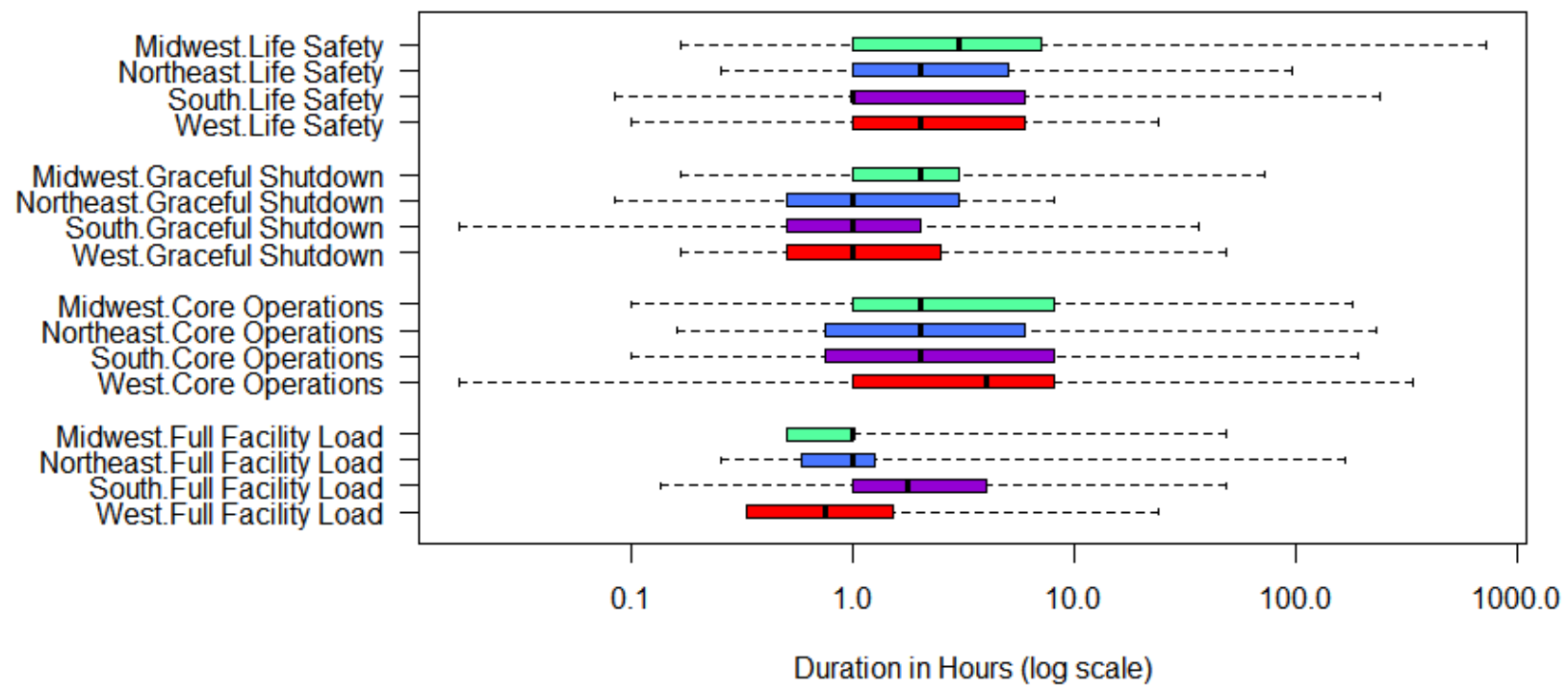

Figure 14: Boxplots UPS Duration by Purpose and Census Region

It can be seen that UPS duration is similar across census regions for each purpose except the full facility load. However, the lack of adequate sample size in any of these categories does not allow a statistical significance test between the different regions. 
Onsite and Electric Power Backup Capabilities at Critical Infrastructure Facilities in the United States

This page intentionally left blank. 


\section{Conclusions}

A total of 3,174 DHS ECIP surveys of critical infrastructure facilities have been conducted between January 1, 2011, and September 2014. Perhaps unsurprisingly, the vast majority of facilities are dependent upon electricity for core operations. Although there are a number of ways to mitigate against the loss of electric power, facilities most often had a backup generator in place, as opposed to internal generation or only a UPS. The use of natural gas as a fuel source leads to almost unlimited generation capabilities, but 85 percent of facilities used diesel fuel to power backup generators. The facilities that were most likely to have a natural gas generator seemed to be linked to some type of emergency response, community wellness, or electric generation and distribution.

The second portion of the analysis focused on analyzing the facilities by census region to identify potential differences amongst the regions and/or types of facilities in each census regions. The facilities in the West census region seem to have less dependence upon electricity as compared to the other regions, which may be a function of the type of facilities within the region. Although the West region does not have the lowest percentage of facilities with backup generator capabilities, it does have a noticeably lower average duration than the other regions. Further analysis revealed that the West had almost half as much natural gas generation capability as the other regions.

Although the sample size is small with regard to the entirety of critical infrastructure across the country, the facilities that have been surveyed through the ECIP program lend some interesting insight into potential differences in backup capabilities and methods across both infrastructure types and regions of the country. As information about more facilities is collected, uncertainty surrounding the results due to sample size will start to decrease, allowing DHS, DOE, and State and local governments, as well as facility owners and operators, to gain insight into the amount of electric dependence across the country and the current mitigation measures in place. This insight could lead to programs aimed at increasing mitigation measures, encourage grant programs, and inspire the development of new methods to increase the resilience of the national critical infrastructure against the loss of one our most critical resources. 
Onsite and Electric Power Backup Capabilities at Critical Infrastructure Facilities in the United States

This page intentionally left blank. 



\section{Argonne}

Global Security Sciences Division

9700 South Cass Avenue, Bldg. 203

Argonne, IL 60439-4854

www.anl.gov 